\title{
Smoking during pregnancy : the haematological status of smoking and non-smoking pregnant women and their offspring
}

Citation for published version (APA):

Mercelina-Roumans, P. E. A. M. (1996). Smoking during pregnancy : the haematological status of smoking and non-smoking pregnant women and their offspring. [Doctoral Thesis, Maastricht University]. Datawyse / Universitaire Pers Maastricht. https://doi.org/10.26481/dis.19960531pm

Document status and date:

Published: 01/01/1996

DOI:

10.26481/dis.19960531pm

Document Version:

Publisher's PDF, also known as Version of record

\section{Please check the document version of this publication:}

- A submitted manuscript is the version of the article upon submission and before peer-review. There can be important differences between the submitted version and the official published version of record. People interested in the research are advised to contact the author for the final version of the publication, or visit the DOI to the publisher's website.

- The final author version and the galley proof are versions of the publication after peer review.

- The final published version features the final layout of the paper including the volume, issue and page numbers.

Link to publication

\footnotetext{
General rights rights.

- You may freely distribute the URL identifying the publication in the public portal. please follow below link for the End User Agreement:

www.umlib.nl/taverne-license

Take down policy

If you believe that this document breaches copyright please contact us at:

repository@maastrichtuniversity.nl

providing details and we will investigate your claim.
}

Copyright and moral rights for the publications made accessible in the public portal are retained by the authors and/or other copyright owners and it is a condition of accessing publications that users recognise and abide by the legal requirements associated with these

- Users may download and print one copy of any publication from the public portal for the purpose of private study or research.

- You may not further distribute the material or use it for any profit-making activity or commercial gain

If the publication is distributed under the terms of Article $25 \mathrm{fa}$ of the Dutch Copyright Act, indicated by the "Taverne" license above, 
Smoking during pregnancy 
Garricia Meccelina-Roumans, Masastricht 1996.

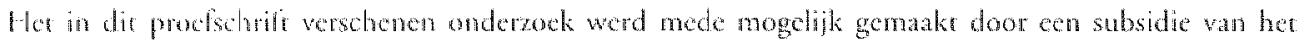
Researthonds van her De Wever-Ziekenhus, de Sricheing Dr. Ir. 1.H.J. van de Laar, Heerten en de Sridhing vor Volksgerondheid en Roken.

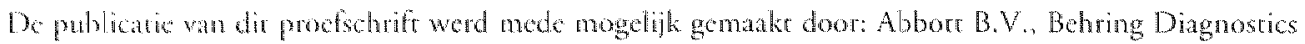
Bemelux N.V., Bochringer Mannheim Nederland B.Y.. Charles Goffin. Ciba Geigy B.V., Organon Nederland B.V., Thanatia B.V., Sarsedr. Schering Nederland B.V.

Ontwerp katr: lan Hendrik Uhachss.

Produktic en druk Dakwyse / Unwersitäre Pers Maustricht. 


\section{Smoking during pregnancy}

The haematological status of smoking and non-smoking pregnant women and their offspring

\section{PROEFSCHRIFT}

ter verkrijging van de graad van doctor aan de Rijksuniversiteit Limburg te Maastricht, op gezag van de Rector Magnificus, Prof. Mr. M.J. Cohen, volgens het besluit van het College van Dekanen, in het openbaar te verdedigen op vrijdag 31 mei 1996 om 14.00 uur

door

Patricia E.A.M. Mercelina-Roumans

geboren te Maastricht in 1964 


\section{Promotores}

Prof. dr. P.). Brombacher

Prof. dr. J. de Haan

\section{Copromotones}

Dr. J.W.J. van Wersch

Dr. J.H.M. Ubachs

\section{Beoordelingscommissie}

Prof dr. M.P. van Dieijen-Visser (voorzicter)

Prof. dr. C.E. Blanco

Prof. dr. dr. H. Greiling, (RWTH, Aken, Duitsland)

Prof. dr. H. C. Hemker

Prof. dr. H.H.H. Kanhai, (Rijksuniversiteit Leiden) 
woor Luc

an mijn ouders

en schoonowders 


\section{Abbreviations}

\begin{tabular}{|c|c|}
\hline AT-III & antithrombin Jll \\
\hline BASO & basophilic granulocytes \\
\hline DDM & D-dimers \\
\hline DNA & desoxyribonudeic acid \\
\hline $\mathrm{EO}$ & cosinophilic granulocytes \\
\hline $\mathrm{F} 1+2$ & prothrombin fragment $1+2$ \\
\hline $\mathrm{FDP}$ & fibrin degradarion produces \\
\hline$F[E]$ & forced expiratory volume \\
\hline$G$ & $\operatorname{giga}=10^{9}$ \\
\hline HCT & haemarocrit \\
\hline HFR & high fuorescence tatio \\
\hline $\mathrm{HGB}$ & haemoglobin \\
\hline $\mathrm{IR}$ & interquartile range \\
\hline L.FR & low fuorescence ratio \\
\hline LYMPH & lymphocytes \\
\hline $\mathrm{MCH}$ & mean corpuscular haemoglobin \\
\hline $\mathrm{MCHC}$ & mean corpuscular haemoglobin concentration \\
\hline $\mathrm{MCV}$ & mean corpuscular volume \\
\hline $\mathrm{MIR}$ & medium fluorescence ratio \\
\hline MONO & monocytes \\
\hline MPV & mean plateler volume \\
\hline NEUT & neurrophilic granulocytes \\
\hline P-LCR & platelet large cell ratio \\
\hline PAI & plasminogen activator inhibitor \\
\hline $\mathrm{PAl}^{\mathrm{P}}$ & plasmin- $\alpha_{2 \text { anriplasmin complex }}$ \\
\hline $\mathrm{PCT}$ & plateletcrit \\
\hline PDW & platelet distribution widrh \\
\hline $\mathrm{PGl}_{2}$ & prostacyclin $I_{2}$ \\
\hline $\mathrm{PLT}$ & rotal platelet coun \\
\hline $\mathrm{RBC}$ & rotall red blood cell count \\
\hline RDW $A \mathrm{CV}$ & red cell distriburion width coefficient of variation \\
\hline $\mathrm{RDN}-\mathrm{SD}$ & red cell distribution width standind devarion \\
\hline RET & rotal reniculocyce count \\
\hline RNA & ribonucleic acid \\
\hline $\mathrm{T}$ & tera $=10^{12}$ \\
\hline HA & rissue plasminogen activator \\
\hline TAT & thrombin-antithrombin III complex \\
\hline U-PA & urokinase plasminogen activator \\
\hline $\mathrm{WBC}$ & total white bilood cell count \\
\hline
\end{tabular}




\section{Contents}

\section{Chapter I}

Introduction 9

\section{Chapter 2}

Smoking and reproduction $\quad 19$

\section{Chapter 3}

Cotinine concentrations in plasma of smoking pregnant women and their infants 33

\section{Chapter 4}

Leucocyte count and leucocyte differential in smoking and non-smoking females during pregnancy 43

\section{Chapter 5}

Erythrocyte count and indices during normal pregnancy of non-smoking and smoking women 53

\section{Chapter 6}

The reticulocyte count and its subfractions in smoking and non-smoking pregnant women $6 I$

\section{Chapter 7}

Plateler count and platelet indices at various stages of normal pregnancy in smoking and non-smoking women 67

\section{Chapter 8}

Coagularion and fibrinolysis in smoking and non-smoking pregnant women 73 


\section{Chapter 9}

Hacmatological variables in cord blood of neonates of smoking and non-smoking mothers 85

\section{Chapter 10}

Cord blood cells and indices: smoking-related differences between the sexes 99

\section{Chapter 11}

On haemostasis in newborns of smoking and non-smoking mothers 107

\section{Chapter 12}

General discussion 115

\section{Chapter 13}

Summary 119

\section{Chapter 14}

Samenvatting 125

Dankwoord I3I

Curriculum vitae 133 


\section{Chapter 1}

\section{Introduction}

In the European Community countries $36 \%$ of the inhabitants smoke. This average is brought down by the low rates of smoking among women in southern Europe. ${ }^{1}$ In the Netherlands $30 \%$ of all women of reproductive age smoke, compared with $36 \%$ of men. Surveys of smoking during pregnancy have shown that the prevalence of smoking in this group of women is high. Several studies have assessed that while approximately $40 \%$ of smokers may reduce their level of robacco consumprion during pregnancy ${ }^{2-4}$, one-third of all pregnant women continue to smoke. 5 Nicotine dependence is the most powerful driving force for continuing the habit?

\section{Tobacco smoke and its constituents}

Tobacco was introduced in Europe from South America in the $16^{\text {th }}$ century. Although its potential for harm was early recognised it was taken up avidly in every sociery that met it. The devastating effects of smoking are caused by the many toxic substances of robacco smoke. Tobacco smoke consists of more than 3600 different compounds ${ }^{8}$ and its composition varies with the type of tobacco and the way it is smoked. The chief pharmacologically active ingredients are nicotine (acute effects) and tar (chronic effects). It can be divided into a particulate phase and a vapour phase. The particulate phase consists of tiny drops. Water and nicotine are its most important compounds. The vapour phase contains substances such as carbon monoxide and nitrogen oxides. Tar is defined as the condensate of smoke minus water and nicotine and contains a large variety of (aromatic) hydro-carbons.

\section{Pharmacology}

Nicotine is an alkaloid formed by the leaves of the tobacco plant (Nicotiana Tabacum). An average cigarette contains approximately $1 \mathrm{mg}$ nicotine. Initially, nicotine stimulates the sympatheric and parasympatheric ganglia via a direcr acerylcholinergic like action. This srimulatory phase may be brief and is followed by a prolonged ganglion blockade resulting from persistent depolarization. Similar excitatory-inhibitory phases occur in the cardiovascular and central nervous systems, as well as at the ncuromuscular junction. The impact of nicotine on the central nervous system is neuroregulatory in nature, with cascading effects on physiological and biochemical functions. The dose-relared effect of 
nicotine on neurotransmitters and neuroendocrine responses constirute an importane component of its pharmacological actions. After a cigarete has been smoked, circulating levels of noradrenaline and adrenaline increase as plasma nicotine levels rise. ${ }^{9}$ This effect is dose-dependent. Dose-related increases were also observed in plasma levels of argininevasopressine, $\beta$-endorphin, adrenocorricotrophic hormone, cortisol, growth hormone and prolactine after smoking. ${ }^{10}$ Circulating levels of thyroid releasing homone, thyoid stimulating hormone and gonadorrophin releasing hormone were not affected by smoking 11,12

The nicotine metabolite corinine is known to relax vascular smooth muscles and to dilate blood vessels in vitro. 13 It decreases blood pressure and reverses the pressor actions of nicotine in anastherized $\operatorname{dog}^{14}$ and induces electroencephalographic activation in conscious rats. ${ }^{15}$ Cotinine is more potent than nicotine in increasing serotonin turnover in the rat cortex. ${ }^{16}$ Little is known about the activity of cotinine concentrations found. in men. Benowiz et al. ${ }^{17}$ observed no change in blood pressure, heart rate or skin remperature after cotinine infusion, effects excremely sensitive to low concentrations of nicotine.

Thiocyanate is a metabolic byproduct of tobacco smoke. Tobacco smoke contains cyanide, most of which is rapidly converted to thiocyanate after absorption in the body. ${ }^{18-19}$ In high doses both cyanide and thiocyanate are toxic. They can act as hypotensive agents, reduce intracellular oxygen utilization by inhibiring cytochromes, interfere with vitamin B12 metabolism, cause degenerarive neurolo-gical disease and alter thyroid function. ${ }^{18-21}$ Thiocyanate has a long half-life ( 14 days) but its levels may also rise moderately through exposures unrelated to smoking, such as dier (vegerables). Carbon monoxide is one of the most important consticuents of tobacco smoke. The concentration of carbon monoxide in tobacco smoke is $1-5 \%$. It is a product of incomplete combustion of tobacco. Carbon monoxide thas a high affinity for haemoglobitu and thus endangers the uprake and release of oxygen. Myocardial oxygen demand is therefore increased. 22,23 High concentrations of arboxyhamoglobin (COHb) in the blood (15\% in heavy smokers) can lad to changes in behaviour and can have negarive effects on the wessel walls. ${ }^{22}$

Various biochmical procedures have been used to estimate exposure to tobacco smoke: concentrations of nicotine, cotinine, carbon monoxide, carboxyhaemoglobin and thiocyanate in blood have been determined.

Nicotine is pharmacologically the most active constituent of tobacco smoke. Fifty to ninety percent of nicotine in smoke is absorbed by the smokers and can be detected in the blood shortly afrer smoking. ${ }^{24}$ In adults the eliminarion half-life of nicotine in blood is approximately 120 minutes and $60 \%$ of the substance is metabolized to cotinine. 17,25 This is mainly accomplished by oxidation of nicotine in the liver. ${ }^{24}$ About $9 \%$ of the nicotine uptake is excreted unchanged in the urine; $60 \%$ is converted into cotinine of which $10 \%$ is excreted as such in the urine. ${ }^{25}$ The level of cotinine in the blood depends on the rate of generation from nicotine and the rate of ellimination from the body. 26 
Cotinine is slowly cleared from the body (total body dearance averaging $72 \mathrm{ml} / \mathrm{min}$ ) and is primarily eliminated by the liver. 26 Renal clearance accounts for abour $17 \%$ of total clearance. In contrast to nicotine dearance, cotinine dearance is insensitive to changes in urinary $\mathrm{pH}$. Because of the low rate of mecabolism and renal excretion, the half-life $(\mathrm{t} / 2)$ of cotinine is approximately 15 hours $(10-20 \mathrm{~h}) .^{24}$ As a consequence of the long cotinine $\mathrm{r} / 2$ there is relarively litule fuctuarion in blood concentrations throughout the day. Corinine concentrations rise gradually in the course of at smoking day, reach a maximum at the end of the day, and persist in relatively high concentrations overnighr. ${ }^{26}$ The plasma nicorine and corinime levels directly after smoking a cigarette depend more on the way the cigarette is smoked than on its nicorine yield. ${ }^{27}$ Smokxers of lower yield nicorine cigaretres have a rendency to compensate by increasing smoke inhalarion.

Various investigarors have chosen thiocyanate as a marker of cigarette smoke cxposure as it has been reported to be an effecrive biochemical marker of exposure $16,20,21$ and it has a long hallf-life (14 days) compared to the half-life of nicotine ( $<120 \mathrm{~min}$ ) and carboxyhaemoglobin (4 hours). $19,27-29$ Carbon monoxide and carboxyhaemoglobin have also been used as indicators of cigarette consumption. $30-33$

The five mentioned methods for the decerminacion of cigarette exposure differ widely in avalability and costs. Measurements based on nicotine have the advantage of being specific to tobacco but acquire expensive laboratory instrumentation. Levels of thiocyanate, carbon monoxide and carboxyhaemoglobin are easier to determine bur may be artificially raised through exposures unrelated to smoking, such as traffic exhaust gases (CO) and diet (thiocyanate). ${ }^{34}$ A few studies have attempted to compare the various biochemical tests. $31-35$ Hill et al. ${ }^{35}$ conclude that plasma and urinary nicotine and cotinine are valid indicators of smoke absorption, while carboxylhaemoglobin levels correlate well with cigarette smoke inthatation. Pojer et al. ${ }^{33}$ reach the same conclusion. larvis en al. ${ }^{34}$ are of the opinion that measurements of cotinine are best used in discriminating smokers from non-smokers and are the most suitable rests for research protocols when accurate categorizarion is essencial.

To understand the effects of maternal smoking on the ferus and neonate an estimate of the degree of feral exposure ro the constituents of cigaretre smoke should be included. The amount of producs of tobacco smoke transmitted ro the fetus varies consistenty, depending on the proporrion of each cigarete consumed, frequency of puffing, depth of inhalarion and maternal merabolism. ${ }^{34,35}$ After birth, the metabolism of the neonate affecrs the levels and duration of exposure to smoke products. For this reason, biochemical measurements of tobacco products such as maternal and cord blood levels of thiocyanate were carried out by Bottoms et al. ${ }^{36}$ They studied feal serum thiocyanate levels in rektion to maternal passive smoking. Among non-smokers, fetal thiocyanate levels were increased in association with passive smoking $(p<0.05)$. During pregnancy nicotine and cotinine pass the placenta and expose the fetus to concentrations similar to those in the blood of the smoking mothers. 37.38 After birth the child may still be 
exposed to these substances through passive smoking or breast feeding. $37,39,40$ Etzel and co-workers ${ }^{38}$ performed cotinine measurements in urine of neonates of smoking and non-smoking women. Cotinine was measured by radioimmunoassay. The urine concentrations found in neonates of smoking morhers were generally lower than in their mothers, but higher than those in neonates of non-smokers. ${ }^{41,42}$ Klein er al. ${ }^{43}$ measured the nicotine and cotinine content of maternal and neonatal hair by radioimmunoassay. A positive correlation between maternal exposure to nicotine and cotinine and the accumularion of these compounds in neonatal hair was found. The authors suggest that measurements of hair may provide a better estimate of long-term systemic exposure to the toxic constituents of cigarettes and may thereby yield a better prediction of fetal risk.

\section{Smoking and biood cells}

Various reports have established that total white blood cell counts are significantly higher in smokers compared to non-smokers. ${ }^{44-46}$ This rise has been attributed mainly to monocyte release. ${ }^{47-49}$ An increased white blood cell count, found in chronic smokers, has been associared with a higher risk of mortality from cancer. ${ }^{50}$ Several investigators have addressed the question of whether smoking can change the functional characteristics of inflammatory cells. They have produced evidence that inflammatory cell migration can either be inhibited or increased by smoking. ${ }^{51-54}$ Bridges et al. ${ }^{52}$ found that aldehydes, also being components of tobacco smoke, are porent inhibitors of neutrophil chemotaxis. However, Totti et al. 53 showed that nicotine may be chemotactic for neutrophils and may enhance neutrophil responsiveness to chemotactic peptides. Other investigators did not observe this finding. ${ }^{54}$ Considering the chemical complexity of smoke and the individual variations in smoking patterns, it remains difficult to resolve whether smoking increases or decreases inflammatory cell responsiveness.

Carbon monoxide, the main component of the vapour phase of tobacco smoke, binds to haemoglobin, replaces oxygen and thus produces hypoxemia 55 , which in the long term can cause polycyrhemia in heavy smokers. ${ }^{56}$ Considerable evidence has accumulated to link smoking and polycythemia. In an American study, haematocrits of blood donors who smoked were significantly higher than those of non-smoking donors. ${ }^{7} \mathrm{~A}$ Danish survey showed a statistically significant correlation berween cigarerte consumption and the haematocrit. ${ }^{58} \mathrm{~A}$ Canadian group described elevations of the haematocrit, haemoglobin and red blood cell count in smoking subjects, with a decline of these variables when the subjects refrained from smoking. ${ }^{59}$ The $\mathbb{B r i t i s h}^{47}$ studied the haematocrit and mean corpuscullar volume in smokers, ex-smokers and those who never smoked. Those who had never smoked and the ex-smokers had similar haematocrir values. The haematocrit was much higher in current smokers and there was a strong dose-response relationship. The mean corpuscular volume was also highest in current 
smokers and it showed a significant dose-response comelation with the amount of cigaretres smoked.

In view of a possible association between smoking, an altered state of the blood platelets and the development of coronary atherosclerosis, several investigators have focused on the influence of smoking upon platelets. 60-62 Cigarette smoke has been reported ro induce platelet activation, an effect mediated mainly by nicotine, and to increase the plateler adhaesion to the vessel wall. 63-66 Aggregarion of platelers is acurely increased by cigarette smoke. ${ }^{67-69}$ Tobaco smoke reduces the production of endothelial cell prostacyclin, an inhibiror of platelet aggregarion. 70 Smoking also causes acute and chronic inhibition of platelet cyclo-oxygenase, which increases the biosynthesis of thromboxane. 71. "Thromboxane is a porent vasoconstrictor and platelet agonist thus leading to stimulation of platelet aggregation. A further finding is that platelet survival is shortened in smokers. This is considered to be an indirect indicaror of platelet activation. 70 Maternal smoking during pregnancy may create a condition of chronic hypoxia for the fetus. This can be the result of the replacement of oxyhamoglobin by carboxyhaemoglobin. ${ }^{21}$ Additionally, structural changes in the placenta 72 as well as decreased placental blood flow 73 may also impair the oxygen supply to the fetus. Increased haemoglobin and haemarocrit levels have been reported in infants of smoking mothers. 74 This fits the hypothesis that maternal smoking creates a hypoxic condirion for the fetus, stimulating the erythropoiesis. Meberg et al. 75 found that the hacmatocrit levels of neonates were higher with increasing cigarette consumption by the mother. This indicates that the higher the maternal smoking level, the stronger the hypoxic stimulus for fetal erychropoiesis. In association with intrauterine growth retardation a ransitory postnatal thrombocytopenia was more frequently found among infants of smoking mothers than among those of non-smokers. ${ }^{76} \mathrm{No}$ data are available on leucocyre counts in neonates of smoking mothers.

\section{Smoking and haemostasis}

Several lines of evidence suggest that smoking affects the coagulation system as shown by higher plasma fibrinogen and thrombin-antithrombin III (TAT-III) lewels. ${ }^{77}$ Studies of fibrinolysis in smokers have shown variable results. $78-80$ Two studies reported that fibrinogen levels were higher and that fibrinolysis was decreased in subjects who smoke. 78,81 In two other studies 82,83 , fibrinolytic acrivity was reported to bo enhanced after smoking, whereas an other group of investigators found no influence of smoking on fibrinolysis. ${ }^{84}$ Kimura et al. ${ }^{85}$ studied the acute effect of cigarette smoking on haemostasis and found simulaneous increases in both coagulability and fibrinolysis during smoking. 


\section{Smoking and pregnancy}

Cigarette smoking is associated with a dose-relared reduction in fecundity and fertility. 86 Once smoking women get pregnant they have an increased risk of having a spontaneous abortion. ${ }^{87}$ An increased risk of antepartum haemorrhage has been described. ${ }^{88}$ Tobacco use during pregnancy is associated with an increase in low birth weight due to both preterm delivery (nicotine has an oxytocin-like effect upon uterine contractility ${ }^{89}$ ) and the delivery of small for gestational age infants. ${ }^{90,91}$ An average decrease in birth weight of $200 \mathrm{~g}$ has been reported. ${ }^{90}$ The association between smoking and perinatal death is disputable. In a review article, Mclntosh stated that only five out of seventeen studies reported a significant increase of srillbirth among smokers. An increased risk of early death was reporred in four studies. Some tobacco-related deaths are probably due to the increased risk of malformations. ${ }^{92}$ The deleterious effects of smoking might be mediated by direct placental DNA damage. ${ }^{93}$ Children of mothers who smoke are admitred rwice as often to the hospital for pulmonary problems. ${ }^{94}$ Studies on maternal smoking and childhood cancer have proved inconclusive. $95-97$

\section{Objectives of the study}

The mechanisms by which cigarete smoking has a negative effect on pregnancy and pregnancy outcome are complex and multifactorial. The aim of this study was to investigate wherher these effects are mediated or reflected by changes in haematological variables in smoking pregnant women and/or their offspring. Consequently, the following objecrives were pursued:

1. The effect of smoking on blood cells and cell indices in mothers (chaprer 4, 5, 6, and 7) and their newborns (chaprer 9).

2. The sex-related differences of nicotine exposure in neonates (chapter 10).

3. The simultaneous effects of smoking and pregnancy on haemostasis (chapter 8).

4. The haemostasis in neonates of smoking and non-smoking mothers (chapter 11).

5. To estimate the degree of neonatal exposure to the constituents of cigaretre smoke. For this purpose cotinine measurements were carried out in maternal blood plasma and cord blood plasma (chapter 3).

\section{References}

1. Bosanqued $N$. Europe and cobacco. BMJ 1992;304:370-2

2. Baric L. Mactrothur C. Heal thoms in pregnancy, Br ] Prev Soc Med 1977:31: 30-8

3. Black P. Who stops smoking in pregnancy? Nursing Times 19855:59-61 


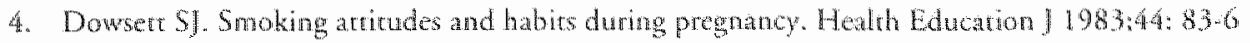

5. Cardozo LD, Gibb DM, Sudd IW, Cooper D]. Social and obsterric feanures associared with smoking in pregnancy. Br J Obster Gynatecol 1982:89:622-7

6. Rubin PC, Craig GF, Gavin K, Sumner D. Prospecrive surwey of use wf the rapeutic drugs, atcohot, and cigareres during pregnancy. Br Med J Clin Red Ed 1986:292:81-3

7. Gillies PA, Madeley RJ. Power FL. Why do pregnant women smoke? Public Heald 1089:103.337-43

8. Wyder EL. Hofman D. Tobacco. In: Schorrenfeld D. Faumeni JE, editors. Cancer epidemiology and prevention. Saunders, 1982:277-92

9. Pomedeau OF, Pomerleau C5. Neuroregulators and the reinforcemene of smoking:cowards a biobehavioral explanarion. Neurosci Biobehav Rev 1984:8503-13

10. Scyler LE Jr, Pomerleau OF, Fertig JB. Hun D. Parker K. Piturary homone response to cigarete smoking. Pharmacol Biochem Behav 1986:24:159.62

11. Syler LE Jr, Ferig ], Pomertea O, Hun D. Parker K. The effecs of smoking on ACT TH and cortisol secretion. Life Sci 1984:34:57-65

12. Pometteau OF. Nicorine and the central nervous sysem: biobchavioural effecs of cigarete sunoking. Am J Med;1993 (supp Ia):2-7

13. Kim KS. Bondellea JF. Bownan ER. McKennis H Jr. Effers of some nicorine metalbolites and related compounds on isolated smooth muscle. J Phamacol Exp Ther 1968:161:159-69

14. Borxelleca JF, Bowman ER, Mckennis H Jr. Studies on the respiratory and cardiovascular eflects of corinine I Pharmacol Exp Ther 1962;137:313-8

15. Yamamoto KI, Domino EF. Nicotine-induced EEG and behavional arousal. In I Neuropharmacol $1965 ; 4: 359-73$

16. Fuxe K, Everitr BJ, Hokfelt T. On the action of niconine and cotinine on central s-hydroxytryptaminc neurons. Pharmacol Biochem Behav 1.979:10:6711-7

17. Benowitz NL, Jacob P 3d. Jones RT, Rosenberg J. Interindividual variability in the merabolism and cardiovascular effects of nicoune in man. J Phamacol Exp Ther 1.982;221:368-72

18. Cohen JD, Bartsch GE A comparison berween carboxylyemogiobin and serum thiocyanate eleterminatrons as indicators of cigarere smoking. Am J Public Healdh 1980;70:284-6

19. Perrigrew AR, Logan RW, Willocks J. Smoking in pregnancy - effects on birth weighn and on cyanide and thocyanate levels in mother and baby. Br J Obsrec Gynaecol 1977;84:31 w4

20. Pirani BB. Smoking during pregnancy. Obsret Gynecol Surv 1978:33:1-13

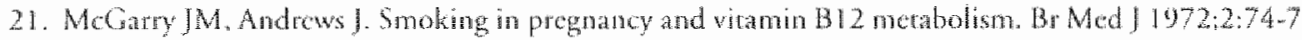

22. Wald H. Harvard S, Smith PG. Kiddsen K. Associanon berween atheroselerotic discases and car boxyacmogobin levels in robacco smokers. Br Med J 1973:1:761-5

23. Kannel WB, Pawber FR, Fredman GD, Clennon WE, MoNanamara PM. Dier factors in hearndisense. An evaluation of serum lipids as predictors of coronary heart disease. Anu Intern Med 1964:61:888-90

24. Curvall M, Enzell CR. Montoring absorption by means of determination of nicorine and cotinine. Arch Taxicol suppl 1986:9:88-102

25. Russell MA. Jarvis M. Iyer R. Feyerabend C. Relation of nicotine yield of cigarenes wo blowd nicotine concentrations in smokers. B. Med』 1980:280:972-6

26. Benowiz NL. Kuyt F, Jacob P 3d, Jones RT, Osman AL.. Cormine disposionon and effects. Clin Pharmacol ther 1983;3:604-11

27. Russell MA. Wilson C, Parel UA, Feyerabend C. Cole PV. Pasma nicotine levels afrer snoking cigarentes with high, medium, and low nicotine yields. Br Med J 1975;2:414-6

28. Pifoce A. Biosynthesis and mammalian meabolism of nicotine. Acta Physiol Sand Suppl 1980:479:13-7

29. Meberg A. Sande H, Fos OP. Stenwig JT. Smoking during pregnancy - cffects on the ferus and on whocyanate lewels in mother and baby. Acta Paediatr Scand 1979;68:547.52 
30. Vogt TM, Selvin S. Widdowson G, Hulley SB. Expled air carbon monoxide and serum thiocyanate ats objecrive measures of cigarere exposurc. Am y Public Health 1977:67:545.9

31. Vescy CI, Saloojec Y, Cole PV, Russell MA. Blood carboxyhaemoglobin, plasma thiocyanate, and cigaterte consumption: implications for epidemiological studies in smokers. Br Med J Clin Res Ed. $1982 ; 284: 1516-8$

32. Wald $\mathbb{N}$, Idle $M$, Boreham $J$. Bailey $A$. Carbon monoxide in breath in relation ro smoking and carboxylaemoglobin levels. Thorax 1981;36:366-9

33. Pojer R, Whitfidd JB, Poulos V, Echard IF, Richmond R, Hensley W]. Carboxy-hemoglobin; cotinine, and thiocyanate assay compared for distinguishing smokers from non-smokers. Clin Chem $1984 ; 30: 1377-80$

34. Jarvis M], Tunstall-Pedoe H, Feyerabend C, Vesey C, Saloojec Y. Comparison of ests used to distinguish smokers from nonsmokers. Am J Public Health 1987;77:1435-8

35. Hill $P$, Haley NJ, Wynder EL. Cigarette smoking: carboxyhemoglobin, plasma nicotine, cotinine and thiocyanate versus selfowcported smoking data and cardiowascular disease. I Chronic Dis 1983;36:439-49

36. Botroms SF, Kuhnert BR, Kuhnert PM. Reese AL. Maremal passive smoking and fecal serum thiocyanare levels. Am J Obster Gynecol 1982;144:787-91

37. Luck W, Nat $H$. Exposure of the ferus, neonate, and rursed infant to nicotine and corinine from maternal smoking. N Engl J Med 1984;311:672

38. Exzel RA, Greenberg RA. Haley NJ, Loda FA. Urine cotinine excrerion in neonates exposed ro robacco smoke products in utero. I Pediatr 1985:107:1.46-8

39. Schwartz-Bickenback D. Schulte Hobein B, Abr S. Plum C, Nau H. Smoking and passive smoking during pregnancy and early infancy: effecs on birth weight, lactation period, and cotinine concentrations in mother's milk and infant's urine. Toxicol Let 1987:35:73-81

40. Luck W. Nau H. Nicotine and cotinine concentrations in serum and urine of infants exposed via passive smoking or milk from smoking mothers. J Paediatr 1985;107:816-20

41. Wald NJ, Boreham J, Bailey A, Rirchie G, Haddow JE, Knighr G. Urinary cotinine as manker of breathing orher people's robacco smoke. Lancer 1984:1:230-1

42. Greenberg RA. Halley NJ, Exzel RA, Loda FA. Measuring the exposure of infants to tobacco smoke. Nicorine and cotinine in urine and saliwa. N Engl J Med 1984;310:1075-8

43. Klein J, Chirayat D, Koren $G$. Hair analysis as a marker for fetal exposure to maremal smoking. $N$ Engl J Med 1993:328 (1):66-7

44. Howell RW. Smoking thabirs and laboratory tests. Lancer 1970:2:152.

45. Corre F, Lellowich J, Schwarta D. Smoking and leucocyte counts. Results of an epidemiological survey. Lance 1971:2:632-4

46. Frichnan GD. Siegelaub, AB, Seltzer CC. Feldman R, Collen MF. Smoking habies and the leukocyce Count. Arch Environ thath 1973;26:137-43

47. Yarnell JW, Sweenam PM, Rogers S, Elwood PC, Bainon D, Baker IA, Eastham R, OBrien JR, Etheringron MD. Some long term effecs of smoking on the haemostatic system: a report from the Caterphilly and Spedwell Collaborarive Surveys. J Clin Pachol 1987:40:909-13

48. Grimm RH Jr, Neaton JD, Ludwig W. Prognostic importance of white blood cell coun for coronary, ancer and allocause mortalicy. JAMA 1985:254:1932-7

49. Phillips AN, Nearon JD, Conk DG, Grimm RH, Slaper AG. The leukocyte conn and risk of lung Gancer. Cancer 1992:69(3):680 4

50. Brownson RC. Nowom TE, Pery MC. Cigarete smoking and adult leukemia. A mera analysis. Areh Intem Mad 1993:153:469-75

51. Mo Cusker KT. Hoidal I. Lcukocye function and chronic bronchisis. Semin Respir Infect 1988;3:5-13

52. Bridges RB, Kraal JH, Huang LJ, Chancellor MB. Efects of cigarette smoke components on in virro chemotaxis of haman polymorphonuclear lcukocyes. Infect Immun 1977;16:240-8 
53. Tarri N 3d, McCusker KT, Campbell E], Grifn GL, Senior RM. Nicone is chemometic for neurophils and enchances neurophil responsiwenes to chemotactic peptides. Science 1984:223:16\%71

54. Sagagawa S. Suzuki K, Sakarani T. Fujikura T. Effecrs of nicotine on the functions of human polymorphonuclear leukocytes in viro. I Leukoc Biol 1985;37:493-502

55. Townsend J. Wilkes $H$. Haines A. Jarws $M$. Adolescent smokers seen in general practice: health, lifescyle, physical measurements, and response ro anrismoking advice. BM/ 1993:303:947-50

56. Goldsnith JR, Landaw SA. Carbon monoxide and human health. Science 1968;162:1352-9

57. Stewart RD, Barera ED. Plate LR, Stewart EB, Kabfleisch JH, wan Yserloo B. Rimm AA. Carboxyhemoglobin levels in American blood donors. JAMA 1974:229:1187-95

58. Isager H, Hagerup L. Relationship berween cigarere smoking and high packed efll wolume and haenoglobin lewels. Scand I Hacmarol 1971;8:241-4

59. Eisen ME, Hammond EC. The effect of smoking on packed cell rolume, red blood cell counts, haemoglobin and plareler counts. Can Med Assor J 1956;82.512-5

60. Kannel WB. Upclate on the role of ciganere smoking in coronary artery discase. Am Heart I $1981 ; 101: 319-28$

61. Friedman GD, Peritri DB, Bawol RD, Siegelaub AB. Mortality in cigamere smokers and quirters. Effer of base-line differences. New Engl J Med 1981;304:1407-10

62. Billimoria JD, Pozner H, Merselar B, Best FW, James DC. Efeer of cigaretre smoking on lipids, lipoproteins, blood coagulation. firinolysis and cellular components of human blood. Artherosclerosis 1975:21:61-76

63. Lassila R, Segterth HW, Haapanen A, Schweer H. Koskenvo M, Lausciola KE. Vasoacrive and atherogenic effects of cigaretre smoking:a study of monozygoric rwins discordan for smoking. BMJ $1988: 297: 955-7$

64. Levine PH. An acute effect of cigarette smoking on platele function. A possible link berween smoking and arterial thrombosis. Circulation 1973;48:619-23

65. Bierenbaum ML. Fleischman AI, Scier A, Somol H, Warson PB. Effect of cigarete smoking upon in wo platelet function in man. Thromb Res 1978:12:1051-7

66. Davis JW. Davis RF. Acute effect of robaco cigarerte smoking on the platelet aggregate ratio. Am J Med Sci $1979 ; 278: 139-43$

67. Davis IW, Shelton L, Eigenberg DA, Hignire CE, Watanabe IS. Effects of wobacco and non tobacco smoking on endothelum and platelets. Clin Pharmacol Ther 1985:37.529-33

68. Fold JD. Gering $S A$, Lably $S W$. Effecr of cigarene smoke and nicotine on plarelets and experimental coronary arrery thrombosis. In: Diana l. cditor, Tobacco smoking and atherosclensis; Pathogenesis and cellular mectanisms. New York. Plenum Publishing 1990:339-58

69. Nowak J, Murray IJ, Oates JA. Fitzgerald GA. Biochemical evidence of a chronic abum malty in phatet and vascular funcrion in healthy individuals who smoke cigarchtes. Circulation 1987:76:6-14

70. US Deparmenr of Health. Education and Wetfare:The hath consequenses of smoking. A report of the surgeon general. Cardiovascular disease. Rockwille, MD, US Department of Hoalth and Human Services, Public Health Service Office of smoking and heath DHHS Publication; 1983 No.PHS 84.50204

71. Benowiz NL.. Drug rherapy. Phamacologic aspects of cigarcte smoking and ricotine addiction. N Engl I Med 1988,319:1318-30

72. Asmussen 1. Ulrastructure of the human placenta ar rerm. Observations on placentas from newbom children of smoking and non-smoking mothers. Acta Obstet Gynecol Scand 1977;56:119-26

73. Spira A, Fournier R, Grob JC, Dreyfus J, Schwanc. D. Smoking during pregnancy and placental blood flow Proc Grh Europ Congress of Perinatal Medicine, Viemna 1978.

74. Garn SM, Shaw HA, McCabe KD. Effect of maternal smoking on henoglobin and hematoctirs of the newhorn. Am J Clin Nurr 1978,31:557-8 
75. Mobery A. Haga P. Sande H. Fow OP. Smoking during pregnancy - hematological observarions in the newborn. Acra Paediar Scand 1979;68:731-4

76. Meberg A, Orstavik 1. Sowde A. Erythroblastemia and thrombocytopenta in small for gestarional age infarts: relation to intraterine hypoxia, infections and maternal smoking. Acra Paediatr Belg $1078.31: 213.8$

77. Belch 11. McArdle BM. Burns P, Lowe GD, Forbes CD. The effecrs of acure smoking on platelet betawiour, fbrinolysis and haemorheology in habitual smokers. Thromb Hacmose 1984:51(1):6-8

78. Meade TW, Chalobarti R. Haines AP, Nort WR, Stirling Y. Characteristics affecting fibrinolyuc acrivity asd plasma fibrinogen concentrations. BMJ 1979;1: 153-6

79. Allen RA, Klufr C. Brommer EJP. An conhancing effect of smoking on Fbrinolysis. Thromb Haemost $1981: 46: 113$

80. Cha FC, Kenney DM, Tullis JL, Alper CA, SAbert JE Alteration in platelet factor 3 acrive in plasma in associarion with cigaretre smoking. Thromb Haemost $1981 ; 46: 433$

81. Lau HK, Rosenberg JS, Beeler DL, Rosenberg RD. The isolation and characterization of a specific antibody population directed against the prothrombin acrwation fragments $\mathrm{F} 2$ and $\mathrm{F} 1+2$. J Biol Chem $1979 ; 18: 8751-61$

82. Allen RA, Klufr C, Brommer EJ. Acute effect of smoking on fibrinolysis: increase in the activity level of circulating exurinsic (rissue-rype) plasminogen activator. Eur J Clin Invest 1984;14:354-61

83. Janzon L. Nilsson IM. Smoking and fibrinolysis. Circulation 1975;51:1120-3

84. Vicari MM, Margonato A. Macagni A, Luoni R, Seveso MP, Vicedomini G, Pozza G. Effects of acure smoking on the hemostatic system in humans. Clin Cardiol 1988;1 1:538-40

85. Kimura $S$, Nishinaga $M$, Otawa $T$, Shimada $K$. Thrombin generarion as an acute effect of cigaretre smoking. An Heart J 1994:128:7\%11

86. Harx AJ, Kelber S, Borkow H, Wild R, Gillis BL, Rimm AA. The associarion of smoking with clinical indicutors of altered sex steroids - a study of 50145 women. Public Healch Rep 1987;102:254-9

87. Alberman E, Creasy M, Ellior M, Spicer C. Maternal factors associated with feral chromosomal anomalies in spontancous abortions. Br J Obster Gynaecol 1976; 83:621-7

88. Underwood P. Hester LL, Laffite T. The relationship of smoking to the ourcome of pregnancy. An J Obster Gynecol 1965:91:270-6

89. U.S. Deparmen of Health, Education, and Welfare. Surgeon General's report. Public Service Health

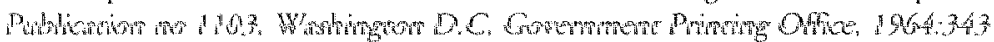

90. Pregnancy and infanc health. In: The health consequences of smoking for women: A report of the surgen general. Washington, DC, United States Department of Health and Human Services, Public Health Service, Offee of the Assistant Sectetary for Health, Office on Smoking and Health, 1980:191-249

3. Meger MB, Tonascia JA. Maremal smoking, pregnancy complicarions, and perinaral mortaliry. Am J Obster Gyned $1977: 128: 494-502$

22. Melnosh 1D. Smoking and pregnancy: II. Oftspring risks. Public Health Rev 1984:12:29-63

93. Shulman LP. Elias S. Tharapel AT, Li LR, Phillips OP. Simpson JL. Sister chromand exchange frequency in direcly prepared cytorrophoblasts demonstration of in vivo deoxyribonucleic acid damage in pregnant women who smoke cigaretes. An J Obster Gynecol 1991:165:1877-80

64. Hatlap 5. Davies AM. Infant admissions ro hospical and maternal smoking. Lancet. 1974:1529-32

95. Sijernfeldr M, Berglund K. Lindsen J, Ludwigsson J. Matemal smoking during pregnancy and risk of childhood cancer. Lance 1986;1:1350-2

96. folun EM. Savitz DA. Sandler DP. [renatal exposure to parents smoking and childhood cancer. Am f Eipidemiol $1991: 133: 123-32$

97. Pershagen G. Ericon A, Otterblad-Olausson $\mathbb{P}$. Maternal smoking in pregnancy: does it increase the risk of childhood cance? Int I Epidemiol 1992;21:1-5 


\section{Chapter 2}

\section{Smoking and reproduction}

Patricia EAM Mercelina-Roumaws, JMH Ubach', JWJ wan Wersch ${ }^{2}$

From the Department of Obstetrics and Gynaccology ${ }^{1}$, and the Department of Hacmatology ${ }^{2}$, De Wever Hospital, Heerlen. The Netherlands.

Fetal and Maternal Medicine Review 1994; 6: 135-141

The literature has been updated 
In the Netherlands approximately $30 \%$ of all women of reproductive age smoke, compared wirh $36 \%$ of men.

Cigarette smoking is associated in women with a dose-related reduction in fecundicy and fertility and in men with a reduction in semen quality. Smoking has a negative effect on pregnancy: increased rates of antepartum bleeding and placenta praevia have been described. Smoking is also associated with increases in the rates of spontaneous abortion, low birth weight and perinatal death. Some tobacco-related perinatal deaths are due to an increased risk of serious malformation. Children of mothers who smoke are admitted twice as often to the hospital for pulmonary problems. However, studies on maternal smoking and childhood cancer have proved inconclusive.

As smoking is a major modifiable risk factor in pregnancy, counselling of women who smoke should have a high priority in antenatal care. The purpose of this review is to summarize the influence of cigarette smoking on the reproductive process.

\section{Smoking and fertility}

\section{Female fertility}

Baird et al ${ }^{1}$ found that $28 \%$ of women who smoked conceived in the first cycle after stopping contraception compared with $38 \%$ of non-smokers and that smokers were 3.4 times more likely to take more than a year to conceive. In a srudy on 35,973 women an increased infertility rate (35\%) was observed among smokers. ${ }^{2}$ Daling et al ${ }^{3}$ found an increased risk of primary tubal inferrility among smokers. In a British study, reduced fertility among women smokers was strongly correlated with the number of cigaretres smoked per day and women smoking more than 15 cigarettes per day had a relarive fertility of 0.79 . The fertility of women who had stopped smoking was the same as that of the non-smokers. ${ }^{4}$

The muscular tone of the oviduct and the amplitude of its contractions are increased in smokers. 5 Smoking therefore seems to affect rubal function and tubal transport of the embryo. These observarions suggest a mechanism for the increased risk of ectopic pregnancy in smokers. Chow er a ${ }^{6}$ found that the relative risk of ectopic pregnancy was increased in both former smokers (relative risk 1.6) and current smokers (relarive risk 2.2). The suggestion that cigaretre smoking is a risk factor for ectopic pregnancy lends support for a possible relarionship berween cigarette smoking and pelvic inflammatory discase. Marchbanks et al ${ }^{7}$ investigated this hypothesis and found that both current and former cigarette smoking were associated with a staristically significant doubling of the relative risk of pelvic intlammatory disease, although no dose-response relationship was observed. The mechanism by which cigarette smoking could yield an increased relative risk of pelvic inflammatory disease is still unclear. 
Nicomine has a negative effect on the wiability and marurity of oocytes. Rosevear at al studied the relation between cotinine concentrations in preovulatory owarian follicles and the ferrilizability of the oocyte during in vitro fertilizacion. They showed that cigarette smoking, as indicated by the presence of corinine in preovulatory follicular fluid, was associated with reduced fertilization of eggs ro approximately wo thirds of the normal rate.

The levels of luceinizing homone are reduced in women who smoke, the LH surge is blocked and the level of prolacrin is increased. 10 The aromatase activity in the ovaries is lower while 2-hydroxylation of oestradiol in the liver is activated, leading ro lower levels of oestrogen ${ }^{11}$ and higher levels of androstenedione. 2 Consequendy, fertility may be impaired by irregular ovulation and secondary amenorhoca. A higher thiocyanide concentration in cervical secretion is said to have a negarive influence on sperm motility. 13

\section{Male fertility}

During recent years the influence of environmental factors on sperm quality has become an importane topic. The results of studies that have been performed to analyze the relationship between cigaretre smoking and semen quality have been contradictory. Some investigators have reported a negative effect of smoking $14-18$, while others have failed to demonstrate any adverse effect. ${ }^{19-23}$ Shaarawy et al ${ }^{17}$ studied the serum endocrine profile and semen characteristics of male smokers and found that smoking led to increased oestrogen and decreased testosterone concentrations. Prolactin and LH levels rose and FSH fell, resulting in decreased sperm production. Vasopressin levels also increased while those of testosterone fell. High vasopressin levels have been shown to relare ro low sperm count and morility. ${ }^{24}$ Osser er a ${ }^{25}$ studied the semen of 186 male smokers and 164 non-smokers in connection with investigarion of their infertility. No statistically significant effect of cigarette smoking on sperm was detected. Marshburn and co-workers ${ }^{26}$ found that smoking alone did not greadly affecr spermarozoa, but that the combination of smoking more than 20 cigarettes and drinking more than four cups of coffee per day significantly reduced sperm motiliry. The combinarion of smoking and varicocele has also been found to be unfavourable ${ }^{27}$

\section{Smoking and pregnancy}

Surveys of smoking in pregnancy have shown that the prevalence of smoking is high and approximately one third of all pregnant Western women continue to smoke. Many factors have been associated with smoking in pregnancy including poor education, lower social class, having a parmer who smokes, being single, and being under 20 years of age. ${ }^{28}$ The main reasons given by pregnant women for smoking include those related 
to mood control (e.g. to calm down, enjoyment, out of boredom) and addiction. 29 Nicotine dependence is the most powerful driving force for continuing the habir.

Nicotine is an akaloid which is the primary component of the particulate phase of tobacco. 30 Nicotine exerts a constricting effect on uterine blood vessels and interferes with the blood supply to the fetus. It also has an oxyrocin-like effect upon uterine contractility 31 , a direct vasoconstrictor effect on the feus ${ }^{32}$, and produces capillary damage in the placenta. 33 The teratogenic effecs of smoking may be caused predominantly by nicotine itself and by its meabolite corinine, both of which pass easily through the placental barrier to the fetal central nervous system 33 . Biological markers show that the ferus is heavily exposed to several components of tobacco smoke. ${ }^{34}$ Carbon monoxide is the primary component of the vapour phase of tobacco smoke. 30 It binds to haemoglobin and produces a conformational change in oxyhaemoglobin. This results in a shift of the oxygen dissociation curve leading to diminished transmission of oxygen to the rissues at a given oxygen tension and thus causing a mild form of hypoxia. 35

\section{Maternal lungfunction}

Lung function changes during pregnancy. Although maximum flow tate and one-second forced expiratory volume (FEV) are not measurably altered 36 , the reduced total pulmonary resistance and increased airway conductance 37 suggeste a bronchodilator effect. This has been attributed to an increased concentration of progesterone, which relaxes smooth muscle ${ }^{38}$ Das er al ${ }^{39}$ investigated the effect of cigarerte smoking on maternal airway function during pregnancy. All spirometric parameters were significantly lower in smokers than in non-smokers. Forced vital capacity, FEV, and the rario of these wo parameters were minimally reduced. The progression of small airway disease was tolated to the level of cigarette exposure. Greater teductions in forced expiratory fow rates and instantancous flows in smokers suggest an increase in small airway resistance and early small airway disease. The changes in airway function in pregnant smokers were similar to those observed in non-pregnant smokers. The authors concluded that the bronchodilator effect expected in pregnancy was not sufficient to overcome rhe deleterious effect of cigarette smoking.

\section{Antenatal complications}

\section{Placental morphology}

Smoking during the first months of pregnancy induces morphologic changes of the placenta. Jauniaux et al ${ }^{\text {t0 }}$ found an increased thickness of the villous membrane and the trophoblastic layer in the placentas of heavy smokers. 
Demir et al ${ }^{4} 1$ studied human placental villi from smoking and non-smoking pregnant women in all three trimesters of pregnancy. The mean birth weight and placental weight in smokers were decreased depending on the cigareres smoked per day in the third trimester. The willi from smokers had abnormalites of the microvilli, focal syncytal necrosis, decreased syncytial pinocycocic activity, and degenerated cytoplasmic organelles. The thickness of the rophoblasric layer increased and feral capillaries were damaged.

\section{Antepartum haemonhage}

Underwood et a ${ }^{42}$ found an increased rate of antepartum haemorrhage in smokers compared with non-smokers. Four studies have demonstrated a positive correlation berween placenta praevia and maternal cigaretre smoking. Kramer et al ${ }^{4.3}$ reported an increased risk of placenta praevia in smokers (odds ratio $1.9: 95 \%$ confidence interval, 1.5 to 2.8). Meyer et al ${ }^{44}$ observed $25 \%$ and $92 \%$ increase in the prevalence of placenta praevia in pregnant women smoking less than, or more than, one pack of cigarertes per day respectively. Williams et al ${ }^{45}$ conducted a case-control analysis of 69 women with placenta praevia and 12,351 controls. The results suggested that smoking during pregnancy was a determinant of placenta praevia. However, they did not confirm Naeye's findings ${ }^{46}$ that the frequency of placenta praevia was more strongly associated with the number of years that morhers had smoked than with their smoking habits during preguancy. The reason for the increased rate of placenta praevia may relate to the fact that placental weight is $0.7-3.6 \%$ greater in smokers. ${ }^{47-49}$ In one of these studies it was found that increased placental weight was accompagnied by $1.9 \%-2.4 \%$ decrease in placental thickness and by a $0.4 \%-1.3 \%$ increase in the smallest diamerer of the placentae of smokers compared with those of non-smokers. ${ }^{49}$ Williams er al ${ }^{45}$ suggested that carbon monoxide-induced. hypoxaemia might result in compensatory placental hypertrophy. Placentae with increased surface areas are more likely to cover the cervical os,

\section{Pre-eclampisia}

The incidence of pre-edampsia and eclampsia seems to show an inverse dose-response relationship with cigarerte consumprion. Kullander and Kallen ${ }^{50}$ reported pre-eclampsia in $11 \%$ smokers compared with $16 \%$ of non-smokers in a Swedish study of more than 6000 pregnant women. This association has been ascribed to the hypotensive effects of thiocyanide derived from cyanide present in cigarette smoke and found in the blood of smokers. 51 


\section{Pregnancy outcome}

\section{Abortion}

Several studies have suggested an increase in the spontaneous abortion race in smokers compared with non-smokers. As early as 1931 , Mgalobeli ${ }^{52}$ reported that women who worked in tobacco factories had fewer pregnancies, more aborrions and a higher infant mortality rate than those who did not. Spontaneously aborted fetuses of women who smoke have a lower frequency of congenital abnormalities. ${ }^{53}$ It has been suggested that smoking can interfere with implantation. However in a study from Finland, Hemminiki et $a^{54}$ were unable to find a significant effect of smoking on spontancous aborrion. Sandah ${ }^{55}$ also showed no effect of smoking on abortion risk. The results of this study actually suggested a slightly reduced odds ratio for spontaneous abortion in smokers.

\section{Birth weight}

Between 1957 and 1990 over a hundred publications, based on studies of more than half a million births, reported that women who smoked during pregnancy had infants of lower birth weight than women who did not. ${ }^{56}$ Tobacco use during pregnancy is associated with an increase in low birth weight due to both preterm birth and the delivery of small for gestational age infants. 57,58 Maternal tobacco use has been reported to cause an average decrease in birch weight of $200 \mathrm{gg}^{59}$. Peacock et al ${ }^{160}$ related birch weight to the number of cigarettes smoked per day and found that there was a reduction in weight of $0.19 \%$ per cigarerte. There was an $8 \%$ reduction in birth weight in the children of mothers who smoked more than 13 cigarettes per day compared with those who smoked less than rhis.

The strength of the association between maternal smoking and lower birth weight, the consistency of the findings and the exisrence of dosage effects, all add up to strong cvidence that the association is causal. ${ }^{56}$

\section{Perinatal mortality}

The association berween smoking and perinatal death was inirially disputed. 61 In a review article, Mclntosh stated that only five of seventeen studies reported a significantly increased risk of stillbirch among smokers. ${ }^{62}$ An increased risk of early death among the infants of smokers was reported in four studies, bur none reached statistical significance. Cnatringius et al ${ }^{63}$ studied risk factors for late feral and early neonatal death. The overall rates were found to be 3.5 and 3.1 per 1000 respecti-vely. The relative risk for early neonatal mortality was increased for multiple birth (4.9) and smoking (1.2). Smokers aged under 35 had a relative risk of late fetal death ranging from 1.1 to 1.6, while the risk was doubled if mothers were above this age. Kleinman et al ${ }^{64}$ found that 
primigravidae who smoked less than one packet of cigaretes per day had a $25 \%$ greater risk of mortality compared with non-smokers while those who smoked one or more packets had a $56 \%$ greater risk. The prevalence of smoking in this population was $30 \%$. It was estimated that if all pregnant women stopped smoking, the number of feral and infant deaths would be reduced by approximately $10 \%$.

\section{Congenital malformations}

Some tobacco-related prenatal deachs are probably due to the increased risk of serious malformation. ${ }^{55}$ An American epidemiological study showed a 1.6-fold increase in the risk of malformation in mothers who smoked more than 20 cigarettes per day during pregnancy. ${ }^{66}$ Swedish workers reported an increased risk of cleft lip and palate in children of mothers who smoked. 67 Rivrud et a ${ }^{68}$ found an increased risk of clef palate and malformarions of the central nerwous system. This risk was dose-dependent. Czcizel and co-workers ${ }^{69}$ found that smoking during pregnancy raises the relative odds for terminat transverse limb deficiencies. These malformations may be caused by mutagens, some of which have been demonstrated in amniotic fluid. Recently a study of cytotrophoblast cells from pregnant women showed placental deoxyribonuclaic acid (DNA) damage among smokers. These findings suggest that the deleterious effect of smoking could be mediated by direct placental DNA damage.70

\section{Paediatric outcome}

\section{Lung function}

Several studies have reported an association beween smoking habits of parents and pulmonary morbidicy in their children. $71-73$ Harlap and Davies ${ }^{2}$ found that the prevalence of hospital admission for bronchitis or pneumonia was twice as high in infants of smokers compared with infants of non-smokers. Tager et al 73 , using pulmonary function studies, documented decreased lung growth during childhood and adolescence in association with parental smoking. The effect on respiratory morbidity appears to be more, although not exclusively, related to maternal rather than patemal smoking. Most studies have also found a greater effec of maternal smoking on the pulmonary function of female children. Whether this is caused by exposure before or after birth is uncertain. It may relate to the fact that mothers spend more time with their childron and that girls share more activities with their mothers than boys. Another possibility might be that maternal smoking during pregnancy retards fetal lung development. Bassi et al 74 developed at model of maternal smoking and demonstrated that fetuses suffered from growth reardation with a predominant effect on lung growth. Deficient tormation of pulmonary septa suggests that growth of the connective rissue of the fetal lung may have 
been impaired during pregnancy. Septal growth may have been reduced by a deficiency of elastic tissue. It is not known whether the lung can recover from structural alterations due to antenatal maternal smoking. A study by Taylor and Wadsworth ${ }^{75}$ supports the concept that maternal smoking influences the incidence of respiratory illness in children mainly through a congenital effect, and only to a lesser extent through passive exposure after birth. Using the British Births Survey, they first confirmed that maternal, but not paternal, smoking was significandly associated with the incidence of bronchitis and hospital admission for lower respiratory tract illness in early life. They were then able to identify subsets of women who either smoked during pregnancy but nor after delivery or who smoked only after their children were born. Reported rates of admission to hospital for lower respiratory tract diseases were found to be as high in children born to mothers who stopped smoking during pregnancy as in those whose mothers smoked during and after pregnancy. No differences in the rates of hospital admission were found in children whose mothers started to smoke only after delivery as compared with children of mothers who had never smoked.

\section{Neuropsychological problems}

Children exposed to maternal smoking in utero are said to have significantly more neuropsychological deficits than children who have not been exposed. Studies of cognitive function of 3-year old children born to mothers who smoked more than 10 cigarettes per day showed a statistically lower level of performance as compared to children of mothers who stopped smoking during pregnancy. ${ }^{76}$ These differences in cognitive functioning persisted after excluding the confounding effects of environmental factors, characteristics of the child and gestational age at birth. However Tong et al7?, in a review article on maternal smoking and neuropsychological childhood development, concluded that the evidence for maternal smoking during pregnancy being a cause of neuropsychological deficits was inconclusive. The effects might have been due to uncontrolled or unknown social and environmental factors.

\section{Childhood cancer}

Transplacental carcinogenesis has been demonstrated in animal experiments with a number of compounds present in tobacco smoke, including several nitrosamines and polyaromatic hydrocarbons. ${ }^{78}$ Cigarette smoke condensate can also increase the number of tumours and hyperplastic laesions in the offspring of treated animals. ${ }^{79}$

The available evidence regarding cancer risks in children of morhers who smoke during pregnancy is inconclusive. Only the studies by Stjernfeldt et $a^{80}$ and John et al ${ }^{81}$ suggested a clear dose-related increase in cancer risk, which was particularly marked for acute leukaemias. Pershagen et a ${ }^{82}$ performed a cohort study, using information from the National Swedish Medical Birth and Cancer Registraties. The maximum follow up 
age was 5 years. They found no increase in overall cancer risk in children of morhers who reported smoking during pregnancy. Further studies are needed to determine if smoking in pregnancy induces cancer in childhood or later life.

\section{Sudden infant death syndrome}

Sudden infant death syndrome (SIDS) is a major cause of post-neonaral mortality in industrialized countries. In addition to prone sleeping position, exposure to tobacco smoke is one of the most important epidemiological risk factors associated with SIDS. ${ }^{83-85}$ Maternal smoking during pregnancy and nursing increases the risk of SIDS in the newborn in proportion to tobacco consumption: moderate smoking by a factor five. ${ }^{86}$ Why tobacco exposure increases the risk of SIDS is unknown. What is known is that parental smoking is associared with lower respiratory tract infections ${ }^{87}$ and that nicotine exposure of the fetus and neonate induces alterations in neurotransmission in the central nervous system ${ }^{88}$ and affects cardiovascular control ${ }^{89}$ Nicotine exposure of rat fetuses and pups has been shown to impair the ability to increase heart rate in response to adrenergic stimulation. ${ }^{89}$ An increased predisposition for cardiac arrhyrhmias and a reduced heart rate variability have been demonstrated in at number of infants who subsequently died of SIDS. ${ }^{90}$ Milerad et al ${ }^{91}$ found high nicotine and cotinine levels in pericardial fluid in victims of SIDS.

\section{Conclusion}

The negative influence of cigarerte smoke and its components on reproduction has been reviewed. Smoking is a major modifiable risk factor in pregnancy. Randomized trials of the effects of counselling in pregnancy have documented an increased rate of disconrinuing smoking. ${ }^{92,93}$ Counselling of women who smoke should have a high priority in antenatal care, not only to prevent low birth weight but also to reduce exposure of infants ro environmental smoke. Pregnant women who continue to smoke should be counselled to stop for their own health and the health of their unborn child.

\section{References}

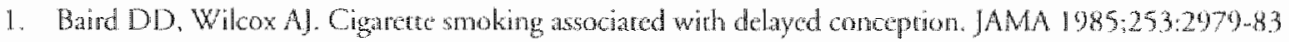

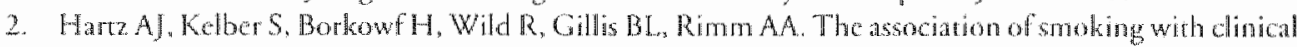

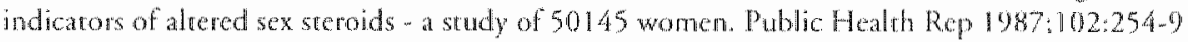

3. Daling I. Weiss N, Spadon L. Mure DE, Voige L Gigareresmokirgand primary rubal infertitity. In: Rosenberg M], editor, Smoking and reproductive health. Liticton, M. PSC, Publishers, 1987:40 6

4. Howe. G. Westhof C, Vessey M, Yeares D. Efect of age cigarerte smoking and ouher facour on fertilin: findings in arge prospectiwe srudy. Brit Med Clin Res Ed 1985, 290:1697-700 
5. Stilman RJ, Rasenberg. MJ, Sachs BP. Smoking and reproduction. Fertil Sreril $1986 ; 46$ - 545-66

6. Chow WH, Daling IR, Weiss NS, Voigt LF. Maternal cigarette smoking and rubal pregnancy. Obsre Gynecol 1988:71:167-70

7. Marchbanks PA, Lee NC. Peterson HB. Cigarcte smoking as a risk factor for pelvic inflammarory discase. Am J Obsre Gynecol 1990;162:639-44

8. Matrison DR. The effects of smoking on ferility from gametogenesis to implantarion. Environ Res 1982,28:410-33

9. Rosevear SK, Holr DW , Le TD, Ford WC, Warde PG. Hull MG. Smoking and decreased fertisation rates in vitro. Lancet $1992,34: 011195-6$

10. Yeh J, Barbieri RL. Efects of smoking on steroid reproduction, metabolism and estrogen - related discase seminars. Reproducrive Endocrinology 1989;7:326-344

11. Babieri RL. McShane PM. Ryan KI. Constituents of cigaretre snoke inhibit human granulosa cell aromatase. Ferul Steril $1986 ; 46: 232-6$

12. Michnowic J], Hershcopf R], Naganuma H, Bradlow HL, Fishman J. Increased 2-hydroxylation of cstradiol as a possible mechanism for the anti-cstrogenic effect of cigarette smoking. $N$ Engl J Med $1986,315: 1305-9$

13. Hehn S. Einfluss von Rhodanid auf die Moulität mensehlicher Spermatozoen nach verschiedenen Einwirkungszeiten und in verschiedenen Konzentrationen. Andrologia 1975:7:255-71.

14. Vician M. Ergebnisse von Spermauntersuchungen bei Zigaretenrauchern. Z Haur Geschlechrskr $1969 ; 44: 183-7$

15. Campbell JM, Harrison KL. Smoking and infertility. Med J Aust 1979;1342-3

6. Evans H), Fetcher J, Forrance M, Hargreawe TB. Sperm abnormalites and cigaterte smoking. Lancer 1981;1:627,9

17. Sharawy M, Mahmoud KZ. Endocrine profile and semen chatacteristics in male smokers. Ferril Sreril $1982 ; 38: 255-7$

18. Handelsman DI. Conway AJ, Boylan LM. Turck JR. Testicular function in potential sperm donors:nomal ranges and the effecs of smoking and varicocele. Ine ] Androl 1984;7:369-82

19. Nebe KH, Schirren C. Staristische Untersuchungen bei andrologischen Patienten. III. Nikotin und Ejakulatparameter. Andrologia 1980;12:493-502

20. Godfrey B. Sperm morphology in smokers. Lancer 1981;i:948

21. Rodrigu\% Rigan LJ, Smith KD, Steinberger E. Cigarerte smoking and semen quality. Fertil Steril $1982: 38: 115-6$

22. Voge H1, Heller WD, Bordli S. Sperm qualiry of healthy smokers, ex-smokers, and never-smokers. Ferril stat $1986: 45: 106-10$

23. Dikshit RK. Buch JG, Mansuri SM. Effect of tobacco consumpton on semen quality of a popularion of hypotertile males Fertil Steril $1987 ; 48: 334-6$

24. Puri $S$, Pun VN Urinary wasopressin in male infertility. Arch Androl 1985; 14: $263-5$.

25. Osser $\$$. Beckman-Randicx A, Licdholm P. Senen qualicy of smoking and non-smoking men in inferte couples in a Swedish population. Acta Obstet Gynecol Scand 1992:71:215-8

26. Mashbum PB. Sloan CS. Hammond MG Semen qualicy and association with coffee drinking, cigarete smoking, and ethanol consumption. Fertil Steril 1989:52:162-5

27. Klaber EL, Bowerman DM, Pokoly TB. Alber AJ, Howard PJ Jr, Sherer JF Jr. Interrelarionships of cigarete smoking, testicular waricoceles and seminal thud indexes. Ferril Steril 1987,47:481-6

28. Madcley RI, Gillics PA. Power FL, Symonds EM. Notringham mothers stop smoking project baseline survey of smoking in pregnancy. Community Med 1989; 11: 124-30

29. Gillies PA, Madeley RJ, Power EL. Why do pregnane women smoke? Public Health 1989;103:337-43

30. Macrunus CF. Developmental neuroroxicity of nicorine, carbon monoxide, and other tobacco smoke constiruents. Ann N Y Acad Sci 1989:562:105-22 
31. US. Deparment of Health, Education, and Welfare Surgeon General's report. Public Heath Serve Publicaron no 1103. Washington D.C. Government Printing Ofher, 1964:343

32. Ross EM, Buter NR, Goldstein H. Smoking hazards to the ferus. BM] 1973:451

33. Mosier HD. Armstrong MK. Efecrs of maternal intake of nioorine on fetal and newhorn rats. Proc Soc Exp Biol Med 1964;116:956

34. Meberg A, Sande H. Foss OP. Stenwig JT. Smoking during pregnancy - thecte on the forus and on thiocyanate levels in mother and baby. Acra Paediat Scand 1979,68:547-52

35. Townsend J, Wilkes H, Hanes A, Jarvis M. Adolescent smokers seen in gencral practice: healh. lifestyle, physical measurements, and response to anrismoking advice. BM] 1991:303:947-50

36. Gazioglu K, Kaltreider NL, Rosen M, Yu PN. Pulmonary funceton during pregnancy in normat women and in patients with cardiopulmonary disease. Thorax 1970;25:445-50.

37. Gee JB. Packer BS. Millen JE, Rubin ED. Pulmonary mechanics during pregnancy. J Clin Invest 1967:46:945-52

38. Hyten E, Leich 1. The physiology of human pregnancy. 2nd ed. Oxford: Blackwell Scisuritic 1971:189

39. Das TK, Mourquin JM, Paren JG. Effecr of cigarerte smoking on maternal airway function during pregnancy. Am J Obster Gynecol 1991:165:675-9

40. Jauniaux E, Burton $G$ ]. The effect of smoking in pregnancy on early placental morpho-logy. Obsret Gynccol 1992,79:645-8

41. Demir R, Demir AY. Yinanc M. Sorucrual changes in placental barrier of smoking mother. A quancitarive and ultrastructural study. Pathol Res Pract 1994;190: 656-67

42. Underwood P. Hester LL, Laffite T. The relationship of smoking to the ourcome of pregrancy. Am J Obsrer Gynecol 1965:91:270 6

43. Kramer MD, Taylor V, Hickok DE, Daling JK, Vaughan TL, Hollenbach KA. Maternal smoking and placenta previa. Am J Epidemiol 1991:2:221-3

44. Meyer MB, Jonas BS, Tonascia JA. Perinatal events associated with matemal smoking during pregrancy. Am ] Epidemiol 1976;103:464-76

45. Williams MA, Mirendorf R, Lieberman E, Monson RR, Schoenbaum SC, Genest DR. Cigarerte smoking during pregnancy in relation to placenta previa. An J Obstet Gynecol 1991;165:28-32

46. Naeye RL. The durarion of maternal cigarerte smoking, fetal and placental disorders. Early Hum Dew $1979: 3: 229-37$

47. Wingerd J, Christianson R, Lovir WV, Schoen EJ. Placental rario in whire and black women: relation to smoking and anemia. Am J Obstet Gyncool 1976:124:671-5

48. Vander Veen F. Fox H. The efect of cigarete smoking on the human placcurat a light and etcon microscopic study, Placenta $1982 ; 3: 243-56$

49. Christanson RE. Gross differences observed in the placentas of smokers and nonsmokers. Am I Epidemiol 1979:110:178-87

50. Kullender $\$$, Kallen 13. A prospective seudy of smoking and pregnancy. Acta Obster Giynecol Scand $1971: 50: 83-94$

51. Andrews 1. McGarry JM. A communiry study of snoking in pregnency. J Obere Gymacol Br Commonw, 1972;79:1057-73

52. Mgabobeli M. Einfluss der Arbeit in der Tabakindustric auf dic Ceschlechtssphäre der Arbeitcrin. Monarssch Gebursh Gynak 1931:88:237.47

53. Alberman E, Creasy M, Ellior M. Spicer C. Maternal factors associated with fetal chomosomal anomalies in spontancous aborrions. Br J Otster Gynacol 1976: 83:621-7

54. Hemminiki K, Mutanen P. Saloniemi I. Smoking and the occurrence of congenital malformations and spontaneous abortions: multiwariate analysis. Am \Obster Gynecol, 1983:145:61-66.

55. Sandahl B. Smoking habits and spontaneous abortion. Eur J Olostet Gyncool Reprod Biol 1989;31:23-31

56. Lumley J, Astbury J. Adwice for pregnancy. In: Chalmer IC. Enkin M, Keirse MJNC, editors. Effective care in pregnancy and childbirh, Oxford University Press, 1989. 
57. Pregnancy and infant heath. In: The health consequences of smoking for women: 1 aport of the streongeneral. Washingron, DC, United stares Deparment of Health and Human Services, Public Heath Service, Offec of the Assistant Secretary for Health, Oftee on Smoking and Health, 1980:191-249

58. Mcyer MB, Tonascia JA. Materral smoking, pregnancy complications, and perinatal morralicy. Am I Obster Gynecol 1977:128:494-502

59. Meycr MB. Jonas BS, Jonascia. JA. Perinatal events associated with matemal smoking during pregnancy. Am / Epidemiol 1976:103:464-76

60. Peacock JL, Bland JM, Anderson HR, Brooke OG. Cigarete smokingand birthweight type of cigarete smoked and a possible theshold effect. Ine I Epidemiol 1991:20-405-12

61. Bakkereig LS, Hofman HJ, Oakley AR Perinatal motraliry. In: Bracken MB. edicor. Permaral cpidemiology, Oxford: Oxford Universing Press, 1984:99-151

62. Mchosh ID. Smoking and pregnancy: II. Ofspring risks. Public Healh Rev $1984 ; 12.29-63$

63. Cnarringius $S$. Haglund $\mathrm{B}$, Meirite $\mathrm{O}$. Cigarere smoleing as risk facror for late feral and carly neonakal dath. BMJ 1988,297:258-61

64. KJeinman JC, Pierre MB Jr, Madans JH, Land GH, Schramm WF. The effeces of maremal smoking on fetal and infan moralicy. An J Epidemol 1988;1.27:274-82

65. Nacye RL Relarionship of cigatrette snoking to congenital anomalies and perinatal death. A prospective study. Am I Pathol 1978:90:289-93

66. Kelscy IL. Dwyer T, Holford TR. Bracken MB. Maternal smoking and congenital malformations: an cpidcmiological study. J Epiderniol Community Health 1978; 32:102-7

67. Ericson A, Kallen B. Westerholm P. Cigarette smoking as an eciologic factor in deft lip and palare. Am J Obster Gynecol 1979;135:348-51

68. Rivrud GN, Berg K. Anderson D. Blowers S, Bjoro K. Mutagenic effect of amnionic Auid from smoking wornen at rem. Mutat Res 1986;171:71-7

69. Cacizel AE, Kodaj I, Lene W. Smoking during pregnancy and congenital limb deficiency. BMJ $1994: 308: 1473-6$

70. Shutman LP. Elias S. Tharape: AT, Li LR, Phillips OP, Simpson JL. Sister chromacid exchange frequency in direcrly prepared cytorophoblasts: demonstration of in vivo deoxyribonudeic acid damage in pregnant women who smoke cigarettes. Am J Obster Gynecol 1991;165:1877-80

71. Rantakallio P. Relationship of matemal smoking ro morbidity and mortalicy of the child up to the age of five. Acta Pacdiat Scand 1978;67:621-31

72. Harlap 5, Davies AM. Infant admissions to hospital and matemal smoking. Lancet 1974:529-32

73. Tager 1B, Weiss ST, Munoz A, Rosner B. Spcizer FE. Longitudinal sudy of she effects of maternal smoking on pulmonary funcron in children. $N$ Engl J Med 1983,309:690-703

74. Bassi IA, Rosso P. Moessinger AC. Blane WA. James LS. Fenal growh retardation due to maternal robaco smoke cxposure in the rat. Pacdiatr Res 1984:18:127-30

75. Taylor B. Wadsworth J. Maremal smoking during pregnancy and lower respiratory tract illness in early life. Anch Dis Child 1987;62:786-91

76. Scxon M. Fox NL, Hebd JR. Prenatal exposure to tobaco: Il. Effects on cognitive funcrioning at age three, In J Epideniol $1990 ; 10: 72-7$

77. Tong S. McMichat AJ Maremal smoking and neuropsychological developmenc in dhildhood: a review of the cridence. Dew Med Child Netrol 1992;34:191-7

78. Napalkov NP. Some general considerations on the problem of ransplacenal carcinogenesis. Transplacental carcinogenesis, Lyon: International Agency for Research on cancer, 1973

79. Nicolov U. Chernozemsky IN. Tumors and hyperplastic lesions in Syrian hamsters following transplacenal and neonatal trearment with cigarete smoke condensate. I Cancer Res Clin Oncol $1979: 94: 249-56$

80. Srjenfeld M, Berglund K. Lindsten J. Ludwingsson J. Maremal smoking during pregnancy and risk of childhood cancer. Lancet $1986: 1: 1350-2$ 
81. John EM, Saviz DA, Sandier DP. Prenatal exposure to parens's smoking and childhood cancer. Am J Epidemiol 1991;133:123\%32

82. Pershagen $G$, Ericon $A$, Orterblad-Olausson P. Maternal smoking in pregnancy does it increase the risk of childhood cancer? Int Epidemiol 1992;21:1-5

83. Michell EA, Taylor BI, Ford RP, Srewart AW. Becroft DM, Thompron IM, et al. Four modifiable and other major risk hetors for cor death: the Now Zealand scudy. I Pacdiat Child Health $1992: 28(5$ uppl 1$): 53-8$

84. Hofman HJ Damus K, Hillman L, Krongrad E. Risk facors for SIDS Results of the National institute of Child Heath and Human Developmene SIDS Cooperative Epidemiologieal Srudy. Ann N Y Acad Sc: $1988: 533: 13-30$

85. Haglund B. Coattingius S. Cigarete smoking as a risk facror for sudden infane death syndrome: a population-based sudy. An J Public Health 1990:80:29-32

86. Mirchell EA, Scragg R, Sewart AW, Becroft DM, Taylor B], Ford RP et al. Resulrs from the first year of the New Zealand cot death study. NZ Med ] 1991:104:71-6

87. Navarro HA, Seidler IJ, Eylers IP. Baker FE, Dobbins SS, Lappi SE, er al. Effecrs of prenatal nicorine exposure on development of entral and peripheral cholinergic topic influences in developing brain. I Phamacol. Exp Ther 1.989;251:894-900

88. Navarro HA, Mills E, Seidler F], Baker FE, Lappi SE, Tayyeb MI, er al Prenatal nicorine exposure impairs beta-adrenergic function; persistent chronotiopic subsensitviry despite recovery from deficits in receptor binding. Brain Res Bull 1990;25:233-7

89. Schwarz PJ, Segancini A. Cardiac innervation, neonaral electrocandiogmphy, and SIDS. A kcy for a novel preventive strategy. Ann N Y Acad Sci 1988;533210-20

90. Schechuman VL, Raerz SL, Harper RK, Garfinkel A, Wilson AJ, Southall DP, et al. Dynamic analysis of ardiac $R-R$ intervals in normal infancs and in infants who subsequenty succumbed to the sudden infan death syndrome. Pacdiatr Res 1992:31:606-12

91. Milerad J, Rays J, Gidlund. E. Nicotine and cotinine fevels in pericardial fuid in vicrims of SIDS. Acta Paediar 1994;83:59-62

92. Windsor RA, Curter G, Morris J, Reese Y, Manzella B, Bartett EE, et al. The effecriveness of smoking cessation methods for smokers in public health maternicy dinics: a randomized trial. Am J Public Health $1985 ; 75: 1389-92$

93. Mayer JP. Hawkins B, Todd R. A randomized evaluarion of smoking cessation interventions for pregnant women at a WIC dinic. Am J Public Hoalth 1990:80:76-8 



\section{Chapter 3}

\section{Cotinine concentrations in plasma of smoking pregnant women and their infants}

Patricia EAM Mercelina-Roumans ${ }^{1}, H^{\prime}$ Schouten $^{2}, J M H$ Ubachs $^{1}, J W J$ wan Wersch ${ }^{3}$

From the Deparment of Obstetrics and Gynaecology ${ }^{1}$, the Department of Methodology and Statistics, University of Limburg and the Department of Hacmatology, De Wever Hospital. Heerlen. The Netherlands. 


\section{Abstract}

In the Netherlands $30 \%$ of all women of reproductive age are habitual smokers. One thitd of these women continue to smoke during pregnawcy. Tobacto smoke consists of more than 3600 different compounds. One of its chief pharnacologically active ingredients is nicotine of which $60 \%$ is metabolized to cotinine. Cotinine is the best available biochemical marker of nicotine consumption because it is specific for tobacco smoke exposure and it has a relatively long mean $t / 2$ of 15 hours.

In the present study nicotine and cotinine concentrations were measured in 25 smoking and 25 non-smoking healthy pregnant women. In all 25 non-smoking pregnant women nicotine and cotinine levels were $<10 \mu \mathrm{glml}$. Light smokers $(<10$ cigarettes/day) were found to bave nicotine blood levels < $10 \mu \mathrm{g} / \mathrm{ml}$ and cotinine levels varying between 40 and $99 \mu \mathrm{g} / \mathrm{ml}$. Heavy smokers ( 210 cigarettes/ day) had nicotine levels $<10 \mu \mathrm{g} / \mathrm{ml}$, but high cotinine levels varying from 115 to $199 \mu \mathrm{g} / \mathrm{ml}$.

Corinine measurements were also determined in 25 neonates of non-smoking mothers and in 34 neonates of smoking mothers. In 9 of these 34 newborns the relationship between maternal and neonatal cotinine concentrations was investigated. Cotinine levels in neonates of non-smokers and women who smoked less than 10 cigarettes/day were below the detection limit of $10 \mu \mathrm{g} / \mathrm{ml}$. Corinine values in neonates whose morhers smoked $\geq 10$ cigarettes/day were significantly bigher than in those whase mothers smoked $\leq 10$ cigarettes/day, but significantly lower than in their mothers.

The results of this study confirm that cotinine is more useful than nicotine in discriminating non-smokers, light and heavy smokers. Cotinine concentrations were significantly lower in the nerovates than in their mothers, but there was a strong positive linear relationship between maternal and neonatal cotinine concentrations.

In the Nerherlands $30 \%$ of all women of reproductive age are habitual smokers. Surveys of smoking during pregnancy have shown that the prevalence of smoking in this group of women is high. Several studies have assessed that while approximately $40 \%$ of smokers may reduce their level of tobacco consumption during pregnancy, one third of all pregnant women continue to smoke. 2,3 Nicotine dependence is the most powerful driving force for continuing the habit. ${ }^{4}$

Tobacco smoke consists of more than 3600 different compounds ${ }^{5}$ and its composition varies with the type of tobacco and the way it is smoked. The chief pharmacologically active ingredients are nicotine and tar. An average cigarette contains approximately 1 mg nicotine.

Cigarerte smoking during pregnancy is associated with a well-documented increase in perinatal mortality and morbidity rates. ${ }^{6,7}$ Most of the adverse effects of smoking are related to chronic fetal hypoxia arising from decreased uteroplacental perfusion and increased levels of carboxyhaemoglobin in fetal blood. ${ }^{8}$ These effects are mainly caused 
by nicotine, tar and carbon monoxide. Nicorine also exerts significant haemodynamic effects in the mother by increasing arterial blood pressure and heart rate.

Fifty to ninety percent of nicotine in smoke is absorbed by the smokers and can be detected in the blood shorty after smoking. 10 In adults the elimination halfulife of nicotine in blood is approximately 120 minutes and $60 \%$ of the substance is metabolized to cotinine 1,12 , of which $10 \%$ is excreted as such in the urine. 12 Corinine is slowly cleared from the body and is primarily eliminated by the liver. 13 Renal clearance accounts for about $17 \%$ of total clearance. Because of the low rate of metabolism and renal excretion, the half-life $(\mathrm{t} / 2)$ of corinine is approximately 15 hours $(10-20 \mathrm{~h}) .10 \mathrm{As}$ a consequence of the long $[/ 2$ there is relatively little fluctuation in blood concentrations throughout the day. Various biochemical procedures have been used to extimate exposure to tobacco smoke: blood concentrations of nicotine, cotinine, carbon monoxide (CO) carboxyhaemoglobin ( $\mathrm{COHb}$ ) and thiocyanate have been determined. Levels of thiocyanate, $\mathrm{CO}$ and $\mathrm{COHb}$ are easy to derermine bur may be artificially raised through exposures unrelated to smoking, such as traffic exhaust gases (CO) and diet (rhiocyanate). ${ }^{14}$

A few studies have attempred to compare the various biochemical rests. Hill at als concluded that plasma and serum cotinine are valid indicarors of smoke absorption, while $\mathrm{COHb}$ levels correlate well with cigaretre smoke inhalation. Pojer er al ${ }^{16}$ reached the same conclusion. Jarvis et $a^{14}$ are of the opinion that measurements of corinine are best used in discriminating smokers from non-smokers.

While the effects of nicotine on the pregnant mother and her ferus have alleady been discussed, litrle is known about the effects of corinine. Benowitz a a ${ }^{11}$ observed no change in blood pressure, heart rate or skin temperature, effects extremely sensitive to low concentrations of nicotine. Keenan et al $^{17}$ assessed that cotinine has psychoactive properties. Clark et $a^{18}$ found that the pharmacodynamic activity of corinine is only 1. 100 of that of nicotine.

Even less is known about the effect of smoking on the actual concentrations of cotinine in smoking pregnant women and their newborns. For this purpose corinine levels were measured simultaneously in maternal blood plasma (study group 1) and cord blood plasma (study group 2).

\section{Subjects and methods}

Nicotine and cotinine concentrations were measured in 25 smoking and 25 non-smoking healthy pregnant women. The measurements were done in the second trimester of their pregnancy. This checkpoint was chosen because Sexton et al ${ }^{19}$ indicated wat by the time a smoker reaches her second trimester of pregnancy she will either quir smoking or will continue to smoke until delivery. A second study group consisted of 25 neonates of non-smoking mothers and 34 neonates of smoking morhers. Of 9 of these 34 
Table 1. Nicotine and cotinine values in light and heavy smokers

\begin{tabular}{|c|c|c|c|c|}
\hline \multirow[b]{2}{*}{$\begin{array}{l}\text { Reference } \\
\text { nange }\end{array}$} & \multicolumn{2}{|c|}{$\begin{array}{l}\text { Light smokers } \\
(\alpha 10 \text { cigaretres/day }) \\
(n=13)\end{array}$} & \multicolumn{2}{|c|}{$\begin{array}{l}\text { Heavy smokers } \\
(\geq 10 \text { cigarettes/day }) \\
(n=12)\end{array}$} \\
\hline & $\begin{array}{l}\text { Wicorine } \\
\times 10 \mu g / \mathrm{ml}\end{array}$ & $\begin{array}{l}\text { Coninine } \\
10-100 \mu \mathrm{g} / \mathrm{ml}\end{array}$ & $\begin{array}{l}\text { Nicotine } \\
>10 \mu \mathrm{g} / \mathrm{ml}\end{array}$ & $\begin{array}{l}\text { Cotinine } \\
\geq 100 \mu \mathrm{g} / \mathrm{m}\end{array}$ \\
\hline & $<10$ & 85 & $<10$ & 119 \\
\hline & $<10$ & 99 & $<10$ & 115 \\
\hline & $<10$ & 63 & $<10$ & 126 \\
\hline & $<10$ & 84 & $<10$ & 152 \\
\hline & $<10$ & 66 & $<10$ & 124 \\
\hline & $<10$ & 67 & $<\mathbb{1 0}$ & 127 \\
\hline & $<10$ & 67 & $<10$ & 135 \\
\hline & $<10$ & 40 & $<10$ & 184 \\
\hline & $<10$ & 85 & $<10$ & 150 \\
\hline & $<10$ & 42 & $<10$ & 198 \\
\hline & $<10$ & 64 & $<10$ & 199 \\
\hline & $<10$ & 87 & $<10$ & 132 \\
\hline & $<10$ & 81 & & \\
\hline
\end{tabular}

Table 2. Cotinine concentrations in smoking mothers and their newborns

\begin{tabular}{lll}
\hline Cigarettes/day & $\begin{array}{l}\text { Neonate } \\
\text { Cotinine } \mu \mathrm{g} / \mathrm{ml}\end{array}$ & $\begin{array}{l}\text { Mother } \\
\text { Corinine } \mu \mathrm{g} / \mathrm{ml}\end{array}$ \\
\hline 5 & $<10$ & 48 \\
5 & $<10$ & $<10$ \\
$6-7$ & $<10$ & 65 \\
10 & $<10$ & 55 \\
10 & $<10$ & 42 \\
$10-15$ & 67 & 68 \\
$10-15$ & 78 & 82 \\
$17 \times 20$ & 102 & 171 \\
20 & 110 & 173 \\
\hline
\end{tabular}

newborns the mothers were investigated to study the relationship between maternal and neonatal cotinine concentrations. In this second group only cotinine levels were determined. Nicorine as well as cotinine levels were determined by gas chromarography. ${ }^{20}$ The measurements were carried out by the Department of Toxicology, University Hospital, Maastricht, the Netherlands. A Hewlett Packard 5890A gaschromatograph 
was used. The detection limit for nicotine and cotinine was $10 \mu \mathrm{g} / \mathrm{ml}$. Reference values for light ( $<10$ cigarettes/day) and heavy smokers $(\geq 10$ cigarettes/day) are mentioned in Table 1 . The nicorine and cotinine measurements of the mothers were performed in venous blood plasma. Blood samples were drawn between 8.30 and $9.00 \mathrm{a} . \mathrm{m}$, at leasr one hour after the last cigarette was smoked. The cotinine measurements in the neonates were performed in venous cord plasma. Venous blood samples of the newborns were obtained from the clamped umbilical cord immediately after delivery. Venous blood samples of their mothers were drawn during labour, $2-5$ hours after the last cigaretre was smoked. The Mann-Whitney- $U$ test was used to compare the differences between the cotinine concentrations in neonates of smoking and non-smoking morhers. The Wilcoxon signed rank test was used to test the significance of differences in the plasma cotinine concentration between smoking mothers and their newborns. The Spearman rank correlation coefficient was used to estimate the correlarion between maternal and neonatal cotinine concentrations.

\section{Results}

In all 25 non-smoking pregnant women nicotine and cotinine levels were $<10 \mu \mathrm{g} / \mathrm{ml}$. The smoking group consisted of 13 women who reported smoking 5-10 cigarettes/day (light smokers) and 12 women who reported smoking 10 or more cigarettes/day. The light smokers were found to have nicotine blood levels $<10 \mu \mathrm{g} / \mathrm{ml}$ and cotinine levels varying between 40 and $99 \mu \mathrm{g} / \mathrm{ml}$. Heavy smokers had nicotine levels $<10 \mu \mathrm{g} / \mathrm{ml}$, but high cotinine levels varying from 115 to $199 \mu \mathrm{g} / \mathrm{ml}$. Of the women who reported smoking more than 15 cigarettes/day (heavy smokers), 3 had cotinine values $>175$ $\mu \mathrm{g} / \mathrm{ml}$.

Cotinine levels in neonates of non-smokers and women who smoked less than 10 cigarettes/day were below the derection limit of $10 \mu \mathrm{g} / \mathrm{ml}$. In Fig 1 the corinine concentrations in neonates are displayed in relation with their mothers' smoking habirs. Cotinine values in neonates whose mothers smoked $\geq 10$ cigarettes/day were significantly higher $(p<0.001)$ than in those whose mothers smoked $<10$ cigarertes/day, but significantly lower than in their mothers $(p<0.01)$. There seems to be a threshold of around 10 cigaretres/day. The cotinine concentrations in the 9 smoking mothers and their infants are shown in Table 2. The correlation between cotinine concentrations in maternal and umbilical vein plasma is illustrated in Fig 2. The Spearman rank correlation coefficient was 0.912 with a $\mathrm{p}$-value of 0.001 . 


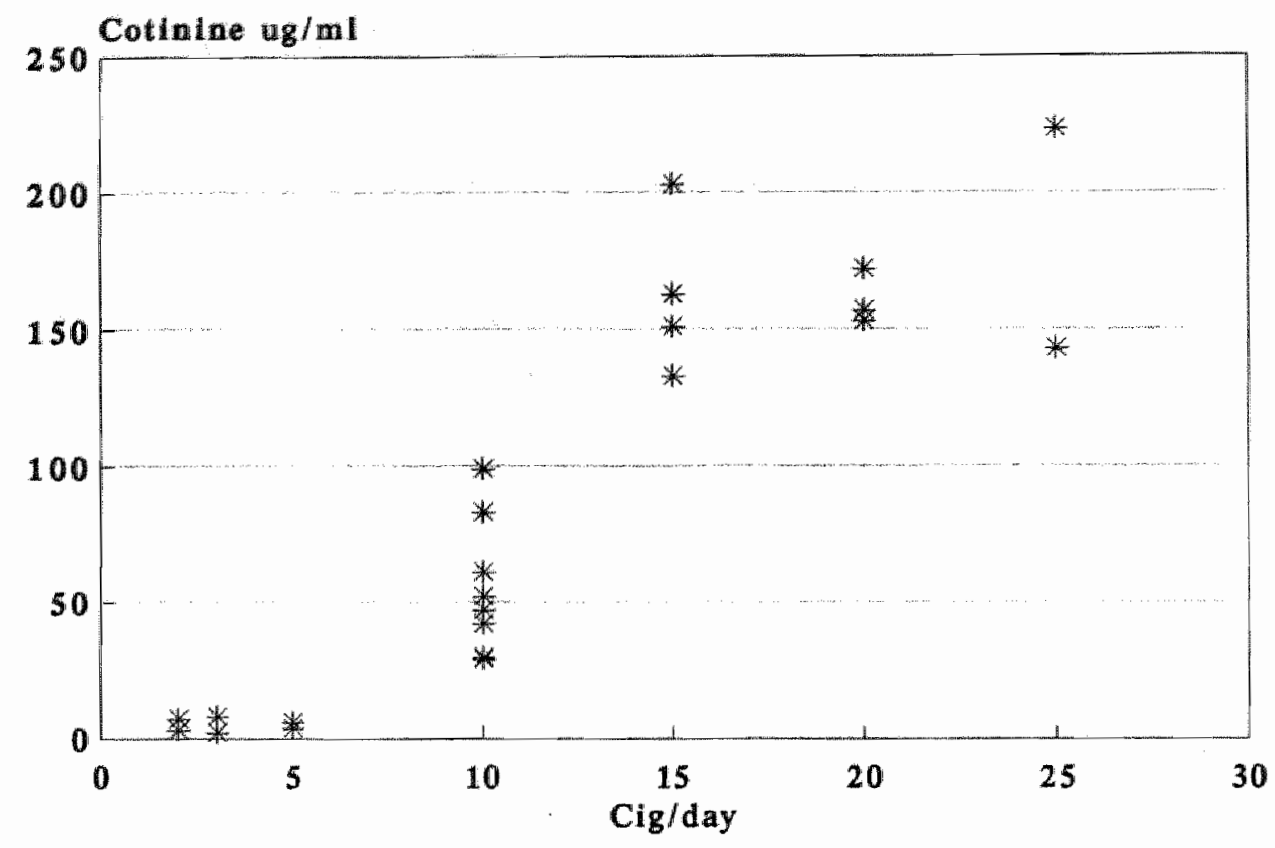

Fig 1. Couinine concentrations in umbilical vein plasma in neonates of smoking mothers

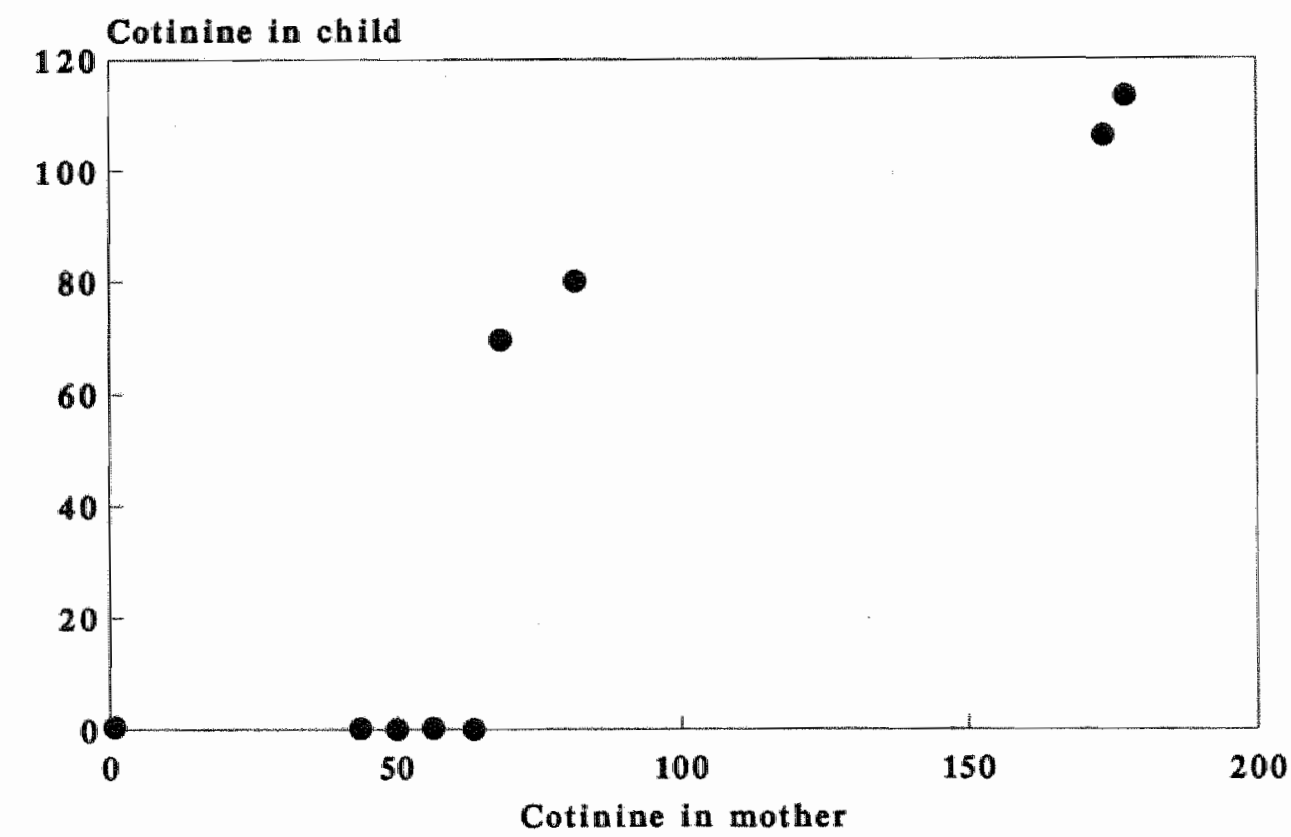

Fig 2. Correlation berween cotinine concentrations $(\mu g / \mathrm{mb})$ in umbilical wein and maternal vein plasma $(\mathrm{rs}=0.912 p<0.001)$ 


\section{Discussion}

Cotinine is a principal merabolite of nicotine and has $a t 1 / 2$ of about 20 h and is the best available biochemical marker of nicotine consumption. $21-24$. The cotinine measurements in our first study group confirm that cotinine measurements are more useful in discriminating non-smokers, light and heavy smokers than nicotine measurements. This is in accordance with earlier findings. ${ }^{23-25}$ Nicotine levels in smokers were below the detection limit of $10 \mu \mathrm{g} / \mathrm{ml}$ because blood samples were taken ar least one hour after the last cigaretre was smoked. In adults the elimination half-life of nicorine in blood is approximately 120 minutes. It is of importance for other studies to know that none of the women of whom the nicotine and cotinine levels were measured underestimated their smoking habits.

The amount of products of tobacco smoke transmitted to the ferus varies consistently, depending on the proportion of each cigarette consumed, frequency of puffing, depth of inhalation and maternal metabolism. ${ }^{14,15}$ After birth, the neonates metabolism affects levels and duration of exposure to smoke products. For this reason, corinine measurements were carried out in neonates of smokers and non-smokers and in neonatal plasma in parallel to maternal plasma. The results of this study show that cotinine is easily transferred to the neonatal compartment. Cotinine concentrations were significandly lower in the neonates than in their morhers $(p<0.01)$, but there was a strong positive linear relationship berween maternal and neonatal cotinine concentrations $\left(r_{s}=0.912\right.$, $\mathrm{p}<0.001$ ). Donnenfeld et al 26 found that fetal cotinine concentrations were abour $90 \%$ of maternal values throughout gestation. Luck et al ${ }^{27}$ found similar cotinine concentrations in smoking morhers and their meonates.

The comparison between neonates of smoking and non-smoking morhers showed cotinine concentrations below the detection limit of $10 \mu \mathrm{g} / \mathrm{ml}$ in neonares of non-smoking mothers and in neonates of mothers who smoked less than 10 cigarettes/ day. Infants of mothers who smoked $\geq 10$ cigarettes/day had significantly higher cotinine levels $(p<0.001)$. There seems to be a threshold around 10 cigarettes/day.

Bardy er a ${ }^{28}$ measured tobacco exposure during pregnancy to study neonatal effects in relation to maternal smoking. They found a quantitative dose and effect relation between tobacco exposure (corinine concentrations) and a decrease in the gestational age at birth and the size of the neonate. It might be a coincidence that Peacock et al ${ }^{29}$ found a threshold of 13 cigarettes per day for the effect of smoking on birth weight.

In conclusion, cotinine is more useful than nicotine in discriminating non-smokers, light and heavy smokers. Cotinine, the principal metabolite of nicotine is easily transferred to the neonate when his/her mother smokes $\geq 10$ cigareres per day. Cotinine concentrations in neonates are significantly lower than in their mothers, but there is a strong positive linear relacionship between cotinine concentrations in the maternal and neonatal compartment. 


\section{Feterences}

1. Bartic L. MacArthur C. Hedrh norms in pregnancy. Br J Prey Soc Med 1977:31:30-8

2. Cardoro LD, Gibb DM, Studd JW, Cooper DJ. Social and obstetric fearures associared with smoking in pregnaney. Bry Obster Gynaecol 1982;89:622-7

3. Rubin PC, Craig GF, Gavin K Sumrer D. Prospective survey of use of therapeuric drugs, alcohol, and cigarettes during pregnancy. Br Med J Clin Res. Ed 1986;292:81-3

4. Cullies PA, Madeley R. Power FL. Why do pregnant women smoke? Public Health $1989 ; 103: 337-43$

5. Wynder EL, Hoffnan D. Tobacco. In: Schorrenfeld D, Fumeni JF, edirors. Cancer epideniology and prevention. Saunders, 1982:277-92

6. Beleh Jy, McArdle BM, Burns P, Lowe GD, Forbes CD. The affects of acure smoking on platelet behaviour, fibrinolysis and haemoneology in habirual smokers. Thromb Haemost 1984;51:6-8

7. Allen RA, Kuft C, Brommer El. Effect of chronic smoking on fibrinolysis. Arteriosclerosis 1985;5:443-50

8. Lelnowitra P. Forss $M$. The acure effec of smoking on intervilous blood flow of the placenta. Br $]$ Obster, Gynaccol 1978; 85: 729-31

9. Quigley ME, Shechan KL, Wilkes MM, Yen SS. Effects of maternal smoking on circulating carcholamine levels and fecal heart rates. Arro J Obstet Gynecol 1979;133:685-90

10. Curvall M, Enzell CR. Moniroring absorption by means of determination of nicotine and cotinine. Arch Toxicol Suppl 1986;9:88-102

11. Benowitz $\mathrm{NI}_{\mathrm{L}}$, Jacols $\mathrm{P} 3 \mathrm{~d}$, Jones $\mathrm{RT}$, Rosenberg $\mathrm{J}$. Interindividual variability in the merabolism and cardiovascular effects of nicotine in man. J Pharmacol Exp Ther 1982; $221: 368-72$

12. Russell MA, Jarwis M, lyer R, Feyerabend C. Relation of niconine yield of cigarertes to blood niconine concentrations in smokers. Br Med J 1980;280:972-6

13. Benowitz NL, Kuyt F" Jacob P 3d, Jones RT, Osman AL. Corinine disposition and effecrs. Clin Pharmacol Ther 1983;3,4:604-11

14. Jarvis MI, Tunstall-Pedoe $H$, Feyerabend $C$, Vesey $C$, Saloojee $Y$. Comparison of tests used ro distinguish smokers from nonsmokers. Am J Public Health 1987; 77,1435-8

15. Hill P. Haley NJ, Wynder EL. Cigarete smoking: carboxyhemoglobin, plasma nicotine, corinine and thiocyanate versus self-reported smoking data and cardiovascular disease.

J Chronic Dis 1983;36:439 49

16. Pojer R, Whitfield JB, I'oulos V. Echthard IE, Richmond R. Hensley W]. Carboxyhemoglobin, cotinine, and thocyanate assay compared for distingushing smokers from non-smokers. Chin Chem $1984: 30: 1377-80$

17. Keenan RM, Hatsukami DK. Pentel PR, Thompson TN, Grillo MA. Pharmacodynamic effects of cotinine in abstinent cigarere smokers. Clin Pharmacol Ther 1994;55:581-90

18. Clark MS. Rand MJ, Vanov S. Comparison of pharmacological activity of nicorine and related alkaloids bcuming in cigatetre smoke. Arch Int Pharmacodyn Ther 1965; 156363

19. Sexon M. Hebel JR. A clinical wal of change in maternal smoking and irs effect on birth weight. JAMA 198:4:251:911-5

20. Jacob P'3d, Wilson M, Benowizz NL. Improved gas chromatographic method for the deremination of nicotine and cotinine in biologic fluids. J Chromatogr 1981:222:61-70

21. Benowitz NL. Kuyt F. Jacob P 3d, Jones RT, Osman AL. Cotinine disposition and effects. Clin Pharmacol Ther 1983;34:604-11

22. Perez-Sable EJ, Benowita NL, Marin G. Is scrum cotinine a better meastre of cigarette smoking than self-report? Prev Med 1995:24:171-9

23. Wald NJ. Idle M. Boreham I. Bailey A. Carbon monoxide in breath in relation to smoking and carboxyhaemoglobin levels. Thorax $1981 ; 36: 366-9$ 
24. Friedman GD, Siegelaub AB, Selter CC, Feldrwar R, Collen MF. Smoking habits and the leukocyto count. Arch Enwiron Health 1973:26:137-43

25. Yarnell JW, Sweenam PM, Rogers S, Elwood PC, Bainon D. Baken IA, Eastham R. O'Brien JR. Etherington $\mathrm{MD}$. Some long term effects of smoking on the lhaemostatic system: a report from the Cacrphily and Speedwell Collaborative Surveys. J Clin Pathol 1987:40;909-13

26. Donnenfeld AE, Pulkkinen A, Palomaki GE, Knight GI. Haddow JE. Simul raneous feral and maremal corinine levels in pregnant women smokers. Am J Obster Gynecol 1993:168:781-2

27. Luck W, Nau H, Hansen R, Steldinger R. Extent of nicotine and cotinine ransfer to the human ferus. placenta and amniotic luid of smoking mothers. Dev Pharmacol Ther 1985:8:384-95

28. Bardy AH, Seppälä T, Lillsunde P, Kataja JM, Koskela P, Pikkaranen J et al. Objectively measured robacco exposure during pregnancy: neonatal effecs and relation to maternal smoking. Br J Obster Gynaecol 1993:100:721-6

29. Peacock JL, BIand JM, Anderson HR, Brooke OG. Cigarerre smoking and birthweight: type of cigatrette smoked and a possible threshold effect. Int J Epidemiol 1991:20:405-12 

Chapter 4

\section{Leucocyte count and leucocyte differential in smoking and non-smoking females during pregnancy}

Patricia EAM Mercelina-Roumans', JMH Ubachs' JWJ wan Wersch ${ }^{2}$

From the Department of Obstetrics and Gynaecology', and the Department of Haematology ${ }^{2}$, De Wever Hospital, Heerlen, The Netherlands. 


\section{Abstract}

The toult leucocyte count was studied in 194 smoking and 518 mon-smoking bealthy pregnant women. Smoking in pregnancy appeared to have an additive enbancing effect on the already known total leucocyle increase in pregnancy. The leucocyte differential count determined in a smaller group of 105 smoking and 288 non-smoking pregnant women, showed that the cosinophil and basophil count was not involved in the white blood cell shift. The rise of the total lewcocyte count was mainly due to an increase of neutrophils, monocytes and lymphocytes. The leucocytosis in the smoking pregnant women was dose-related: significant upward jumps of the percentages of Leucocytosis were observed between 12 and 15 cigarettes/day as well as between 19 and 20 crgarettes/day. Further investigation as to the relevance of these observations for pregnancy and fetal well being bas to be conducted.

The total white cell count has been described to rise in pregnancy, due to an increase in neutrophil polymorphonudear lewcocytes. The neutrophil count also rises at the time of the oestrogen peak of a normal menstrual cycle, and if fertilization has occurred the neutrophils continue to rise. ${ }^{2}$ They reach a peak at 30 weeks and a plateau during the third trimester. ${ }^{3}$ The mean total white cell count is then around $9.0 \times 10^{9} / 1$, the mean neutrophil count about $6.6 \times 10^{9} / 1.1$

The various reports on monocyte count in pregnancy are not unanimous. Hawes et al ${ }^{\text {ft }}$ found an increase of monocytes in pregnancy, others reporred that the monocyte count does nor change 5,6 The lymphocyte count is said not to alter significantly during pregnancy. ${ }^{3}$ An elevation of the leucocyte count has also been reported as a consequence of habitual smoking and has been atrribured mainly to monocyte release. ${ }^{7-9}$ Aim of this study was to investigate whether smoking in pregnancy has an additive effect on the already known leucocyre enhancing effect of each separarelly. The leucocyte differential count was conducted simultaneously in a smaller group of women ro assess which cell kind is predominantly involved in a possible white blood cell shift. Finally the percentual occurrence of leucocytosis in relation with the number of smoked cigarettes per day was established.

\section{Subjects and methods}

A total of 518 non-smoking and 194 smoking pregnant women consecurively atrending the department of gynaecology and obsterrics of the De Wever Hospital, Heerlen, The Netherlands between july 1992 and april 1993, for monitoring of their pregnancy were included in the study. Exclusion criteria were a diastolic blood pressure $\geq 90 \mathrm{mmHg}$, an endocrine disease, a coagulacion disorder or medication known to interfere with the hatemostatic sysrem. Parous women with a history of (pre)eclampsie, hypertension, diabetes, a coagulation disorder, solutio placentae, immature or premature delivery 
and/or a baby small for gestational age were excluded from the study. Twenty percent of the non-smokers and $17 \%$ of the smokers used ferro medication. The known duration of the gestation was based upon the last menstrual date and confirmed by ultrasound determinations between 8 and 14 weeks. The number of cigarettes per day was an estimation of the patient at the intake i.e. at the gestational age at which the leucocyte count was measured, in most cases confirmed by her partner. The basic characteristics of these patients are given in Table 1 . The leucocyte counr was conducted in all patients. The leucocyte differential was counted in a smaller group of 288 non-smoking and 105 smoking pregnant women, after the changes in the leucocyte count became clear. For the evaluation they were ranked in four groups according their gestarional age: 0-10 weeks, 11-20 weeks, 21-30 weeks and 31-40 weeks of gestarion.

Blood samples were drawn between 8.30 and $9.30 \mathrm{a} . \mathrm{m}$. The samples were drawn into EDTA-K $K_{2}$ containing tubes (Sarstedt, Nümbrecht, Germany) and kept at room temperature for maximally 5 hours before they were run on the Sysmex NE-8000 (TOA Medical Electronics Corp., Kobe, Japan).

The significance of the differences of the median values of the various groups was assessed by the Mann-Whitney-Wilcoxon test. The significance of the percentages of patients with leucocytosis was rested by the Chi-square method.

Table 1. Basic chataceristics of the 288 non-smoking and 105 smoking pregnant women

\begin{tabular}{|c|c|c|c|c|c|c|}
\hline Groups of patients & $\begin{array}{l}A g \\
(\text { years })^{\text {a }}\end{array}$ & $\begin{array}{l}\text { Gestation } \\
(\text { days })^{a}\end{array}$ & $\begin{array}{l}\text { Number of } \\
\text { cigaretres } \\
\text { per day }\end{array}$ & $\begin{array}{l}\text { Frequency } \\
\%\end{array}$ & $\begin{array}{l}\text { Birthweight } \\
(\mathrm{g})^{\mathrm{b}}\end{array}$ & $\begin{array}{l}\text { Placental weighe } \\
(\mathrm{g})^{\mathrm{b}}\end{array}$ \\
\hline $\begin{array}{l}\text { Nulliparous women } \\
\text { Non-smokers }\end{array}$ & $\begin{array}{l}30 \\
(27-33)\end{array}$ & $\begin{array}{l}184 \\
(82-227)\end{array}$ & 0 & 44.3 & $\begin{array}{l}3400 \\
(398)\end{array}$ & $\begin{array}{l}543 \\
(264)\end{array}$ \\
\hline Smokers & $\begin{array}{l}29 \\
(25-32)\end{array}$ & $\begin{array}{l}168 \\
(70-224)\end{array}$ & $\begin{array}{l}10 \\
(5-15)\end{array}$ & 45.7 & $\begin{array}{l}319 \\
(534)\end{array}$ & $\begin{array}{l}506 \\
(128)\end{array}$ \\
\hline $\begin{array}{l}\text { Parous women } \\
\text { Non-smokers }\end{array}$ & $\begin{array}{l}30 \\
(27-33)\end{array}$ & $\begin{array}{l}184 \\
(82-227)\end{array}$ & 0 & 55.6 & $\begin{array}{l}3607 \\
(458)\end{array}$ & $\begin{array}{l}565 \\
(192)\end{array}$ \\
\hline Smokers & $\begin{array}{l}29 \\
(25-32)\end{array}$ & $\begin{array}{l}168 \\
(70-224)\end{array}$ & $\begin{array}{l}10 \\
(5-15)\end{array}$ & 54.2 & $\begin{array}{l}3340 \\
(553)\end{array}$ & $\begin{array}{l}547 \\
(145)\end{array}$ \\
\hline
\end{tabular}

a values represent median (IR); balues represent mean (SD). 


\section{Results}

Table 2 shows the comparison of the white blood cell and differential count in smoking and non-smoking women during normal pregnancy. The median leucocyte, granulocyte, lymphocyte and monocyte counes were significantly higher in smokers than in non-smokers.

In Table 3-5 the course of the granulocytes, lymphocytes and monocytes is given from the beginning of pregnancy until the end in four steps $(0-10,11-20,21-30,31-40$ weeks) in the smoking and non-smoking groups.

Fig 1 shows that the percentage of patients with a leucocytosis (i.e. leucocyte values above $10 \times 10 \%$ varied berween $61-63 \%$ at a smoking quantity of $3-12$ cigarettes per day. Between 12 and 15 cigarettes/day this percentage rose significantly to about $70 \%$ $(p=0.02)$, whereas at a smoking quantity of more than 20 cigarettes/day leucocytosis percentages of 82 and $83 \%$ were assessed, which was significantly higher than the $70 \%$ at 19 cigarettes per day $(p<0.0001)$.

Table 2. Differences of the median leucocyte and differential counts tested with the Mann-Whitney-Wilcoxon test

\begin{tabular}{|c|c|c|c|}
\hline & $\begin{array}{l}\text { Normal pregnancy, } \\
\text { non-smokers a }\end{array}$ & $\begin{array}{l}\text { Normal pregnancy, } \\
\text { smokers }\end{array}$ & $\begin{array}{l}\text { Significance } \\
\text { p-value }\end{array}$ \\
\hline Sample size & 518 & 194 & - \\
\hline Lencocytes $\left(10^{9} / 1\right)$ & $\begin{array}{l}9.1 \\
(7.7-10.5)\end{array}$ & $\begin{array}{l}10.7 \\
(8.8-12.5)\end{array}$ & $<0.00001$ \\
\hline Sample size & 288 & 105 & - \\
\hline Granulocytes & $\begin{array}{l}7.04 \\
(5.71-8.25)\end{array}$ & $\begin{array}{l}7.45 \\
(6.28-9.24)\end{array}$ & 0.02 \\
\hline Lymphocytes & $\begin{array}{l}1.74 \\
(1.47-2.04)\end{array}$ & $\begin{array}{l}2.06 \\
(1.66-2.59)\end{array}$ & $<0.00001$ \\
\hline Monocyres & $\begin{array}{l}0.42 \\
(0.30-0.54)\end{array}$ & $\begin{array}{l}0.46 \\
(0.39-0.58)\end{array}$ & 0.003 \\
\hline Eosinophils & $\begin{array}{l}0.10 \\
(0.07-0.15)\end{array}$ & $\begin{array}{l}0.11 \\
(0.08-0.16)\end{array}$ & n.s. \\
\hline Batsophils & $\begin{array}{l}0.03 \\
(0.02-0.03)\end{array}$ & $\begin{array}{l}0.04 \\
(0.02-0.05)\end{array}$ & n.s. \\
\hline
\end{tabular}

\footnotetext{
" values represent median (IR).
} 
Table 3. Comparison of the granulocyte counts of the smoking $(S)$ and non-smoking (NS) females at lour stages during pregnancy

GRANULOCYTES

\begin{tabular}{|c|c|c|c|c|c|c|c|c|}
\hline \multirow{2}{*}{$\begin{array}{l}\text { Gestational age } \\
\text { (weeks) } \\
\text { Parient groups }\end{array}$} & \multicolumn{2}{|l|}{$0-10$} & \multicolumn{2}{|c|}{$11-20$} & \multicolumn{2}{|c|}{$21-30$} & \multicolumn{2}{|c|}{$31-40$} \\
\hline & $\begin{array}{l}1 \\
\text { MS }\end{array}$ & $\begin{array}{l}2 \\
5\end{array}$ & $\begin{array}{l}3 \\
\text { NS }\end{array}$ & $\begin{array}{l}4 \\
5\end{array}$ & $\frac{5}{15}$ & $\begin{array}{l}6 \\
5\end{array}$ & $\begin{array}{l}7 \\
\mathrm{NS}\end{array}$ & $\begin{array}{l}8 \\
9\end{array}$ \\
\hline Number & 50 & 30 & 39 & 18 & 76 & 26 & 123 & 31 \\
\hline Median $\left(10^{9} /\right)$ & 5.52 & 6.16 & 6.61 & 6.94 & 7.02 & 8.00 & 7.83 & 8.49 \\
\hline Lower quartile & 4.73 & 5.25 & 4.97 & 5.60 & 6.08 & 6.80 & 6.46 & 7.85 \\
\hline Upper quartile & 6.38 & 7.18 & 8.10 & 8.44 & 792 & 9.81 & 8.83 & 10.60 \\
\hline $\begin{array}{l}\text { P-valuc of Mann- } \\
\text { Whitney-Wilcoxon-test }\end{array}$ & \multicolumn{2}{|c|}{0.09} & \multicolumn{2}{|c|}{0.48} & \multicolumn{2}{|c|}{0.007} & \multicolumn{2}{|c|}{0.003} \\
\hline
\end{tabular}

Table 4. Comparison of the lymphocyte counts of the smoking (S) and non-smoking (NS) females at fout stages during pregnancy

\section{LYMPHOCYTES}

\begin{tabular}{|c|c|c|c|c|c|c|c|c|}
\hline \multirow{2}{*}{$\begin{array}{l}\text { Gestarional age } \\
\text { (weeks) } \\
\text { Parient groups }\end{array}$} & \multicolumn{2}{|l|}{$0-10$} & \multicolumn{2}{|c|}{$11-20$} & \multicolumn{2}{|c|}{$21-30$} & \multicolumn{2}{|c|}{$31-40$} \\
\hline & 1 & $\begin{array}{l}2 \\
5\end{array}$ & $\begin{array}{l}3 \\
\text { MS }\end{array}$ & $\begin{array}{l}4 \\
S\end{array}$ & $\begin{array}{l}5 \\
\mathbb{N S}\end{array}$ & $\begin{array}{l}6 \\
5\end{array}$ & $\frac{7}{\mathrm{NS}}$ & $\begin{array}{l}8 \\
5\end{array}$ \\
\hline Number & 50 & 30 & 30 & 18 & 76 & 26 & 123 & 31 \\
\hline Median $\left(10^{9} / 1\right)$ & 1.78 & 2.36 & 1.81 & 1.87 & 1.63 & 1.86 & 1.74 & 2.22 \\
\hline Lower quartile & 1.49 & 1.87 & 1.46 & 1.43 & 1.40 & 1.66 & 1.69 & 1.70 \\
\hline Upper quarrile & 2.16 & 2.95 & 209 & 2.25 & 1.86 & 2.07 & 2.06 & 2.71 \\
\hline $\begin{array}{l}\text { p-walue of Mann- } \\
\text { Whitney-Wilcoxon-test }\end{array}$ & \multicolumn{2}{|c|}{0.0001} & \multicolumn{2}{|c|}{0.79} & \multicolumn{2}{|c|}{0.008} & \multicolumn{2}{|c|}{$<0.0001$} \\
\hline
\end{tabular}


Table 5. Comparison of the monocyte counts of the smoking (S) and non-smoking (NS) females ar four stages during pregnancy

\section{MONOCYTES}

\begin{tabular}{|c|c|c|c|c|c|c|c|c|}
\hline \multirow{3}{*}{$\begin{array}{l}\text { Cestational age } \\
\text { (weeks) } \\
\text { Paticnt groups }\end{array}$} & \multicolumn{2}{|l|}{$0-10$} & \multicolumn{2}{|c|}{$11-20$} & \multicolumn{2}{|c|}{$21-30$} & \multicolumn{2}{|c|}{$31-40$} \\
\hline & 1 & 2 & 3 & 4 & 5 & 6 & 7 & 8 \\
\hline & NS & s & NS & S & NS & $\$$ & NS & 5 \\
\hline Number & 50 & 30 & 39 & 18 & 76 & 26 & 123 & 31 \\
\hline Median $\left(10^{\circ} / 1\right)$ & 0.39 & 0.48 & 0.39 & 0.53 & 0.41 & 0.45 & 0.46 & 0.43 \\
\hline Lower quartile & 0.31 & 0.42 & 0.34 & 0.45 & 0.31 & 0.35 & 0.35 & 0.38 \\
\hline Upper quarrile & 0.48 & 0.57 & 0.50 & 0.67 & 0.53 & 0.60 & 0.58 & 0.54 \\
\hline
\end{tabular}

p-vitue or Mann-

$\begin{array}{lllll}\text { Whitncy-Wilcoxon-twst } & 0.006 & 0.02 & 0.18 & 0.90\end{array}$

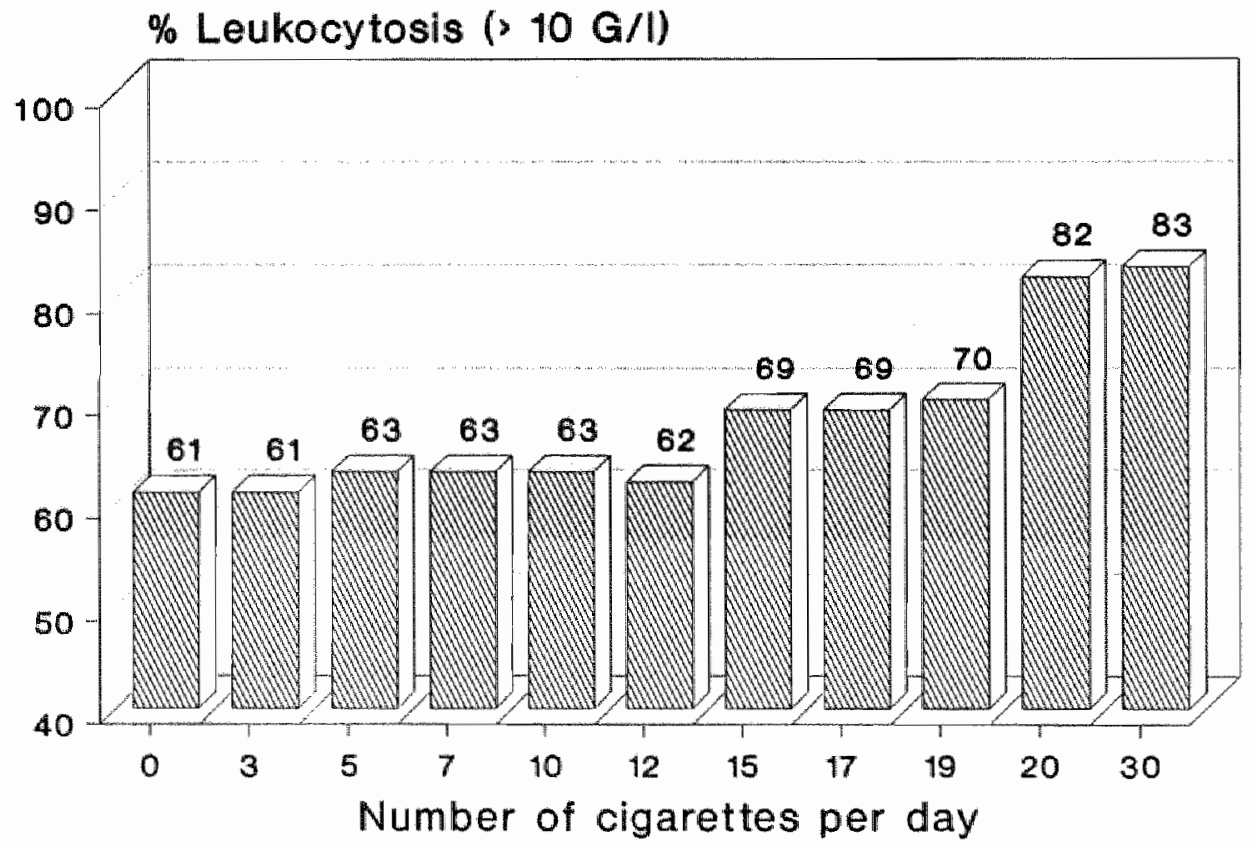

Fig 1. Cumularive frequency oflleucocytosis (i.e. leucocye coune $>1.0 \times 10^{\%} / \mathrm{l}$ ) with increase of the number of eigaretes per day 


\section{Discussion}

The present study was designed prospectively and has to be seen as an initial study to test the impact of smoking on the leucocytes during pregnancy. Various reports have established that total white blood cell counts are significantly higher in smokers compared with non-smokers. ${ }^{10-12}$ Effects of smoking on the haematological system have been reported in the Caerphilly and Speedwel Collaborarive Surveys, a srudy on risk factors for ischemic heart disease. ${ }^{7}$ Haematocrir and whire cell coune were found to be much higher in smokers than in ex-smokers and non-smokers. Dose response relations were apparent in current smokers in terms of white cell count, packed and mean cell volumes. Smoking in pregnancy has an additive effect on the already known leucocyte increase in pregnancy. The reason for the leucocytosis in pregnancy is not known. Although it is difficult to find an explanation for the fact that smoking increases the number of leucocytes in pregnancy, the consequences of these changes might be of importance. The leucocyte differential coune shows that the eosinophil and basophil count is not involved in the whire blood cell shift. The increase in total leucocyte count is mainly due to an increase in neutrophils, monocytes and lymphocytes. Neutrophils are necessary in the body's first reaction to micro-organisms, whereas monocytes and lymphocytes ( $T$ and $B$ cells) are part of the humoral and cell mediated immunicy. Damm et al ${ }^{13}$ studied the distribution of peripheral $T$ cells, monocytes/granulocytes, natural killer cells and B cells in aborting women. They established that the normal pregnancy has no influence on the distribution of mononuclear cells. In cases with threatening abortions the number of monocytes/granulocytes and natural killer cells was increased if the loss of pregnancy occurred. It is not clear wherher the leucocytosis is a reaccion to the abortion or vice versa. Cell mediated immunity is depressed in normal pregnancy in order to be able to accept the feral allograft. Monchamont et al ${ }^{14}$ conducted a study to find our wherher lymphocyte subsers are modified by pregnancy. T lymphocyec subsers, narural killer cells and CDI lat cells decreased during pregnancy. The aurhors stated that these findings partially explain the tolerance for the ferus. Lencocyte metabolism is related to fetal growth. ${ }^{16-14}$ Mercoffe ${ }^{4}$ al ${ }^{19}$ demonstrated a decreased activity of the enzymes adenylate kinase and pyruvate kinase in leucocytes of the cord blood and in maternal leucocytes in children with intraurerine growth retardation. Cartbone et al ${ }^{\text {lt }}$ studied maternal leucocyte metabolism in pregnancy. The results of their study indicate that the energy metabolism, as measured by enzyme activities and adenine nucleoride levels, increases during the first half of pregnancy in women who deliver fullterm babies with a normal weight.

There is no doubt that smoking has an effect on pregnancy ourcome. Simpson reported as early as 1957 that smoking during pregnancy increases the risk of premature birth. ${ }^{20}$ The association between smoking and perinatal death is disputed. ${ }^{21}$ An effect of smoking on birth weight is a constant finding. Most studies have found a dose clependent effect of smoking on birch weight. ${ }^{22}$ Peacock ${ }^{23}$ found a threshold for the effect of 
smoking on birth weight. The threshold level was 13 cigaretres. In the present study a break-point in the percentage of leucocyrosis is found at 12 cigarettes per day, which might be fortuitous, but it is congruent with the results of Peacock.

The effect on intrauterine smoke exposure of the child is not only found in a reduction of birth weight. Several studies have reported an association between maternal smoking and pulmonary morbidity of her offspring. ${ }^{24}$ Children exposed to maternal smoking in utero are said to have significant more neuropsychological deficits than children who are not exposed. ${ }^{25}$ Two studies indicate a clear dose-relared increase in cancer risk in children of mothers who smoked in pregnancy, which was particularly marked for acure leukaemias. 26,27

In conclusion, the effects of smoking in pregnancy are numerous and the leucocyte enhancement is one of them. Further investigations, however, have to be conducred to establish whether this effect is adverse for pregnancy and fetal well-being.

\section{References}

1. Efrati P. Presenrey B, Margaloth M, Rozenszajn L. Lencocyes of nomal pregnant women. Obstet Gyncol 1964:23:49

2. Cruickshank M, Morris R, Butt WR, Crooke AC. The relationship of total and differential leukocyte counts with urinary oestrogen and plasma cortisol levels. J Obstet Gynaecol Br Commonw 1970,77:634-9

3. Cruickshank JM. The effects of parity on the lacocyte count in pregnant and non-pregnant women. Br J Hacmatol 1970:18:53:-40

4. Hawes CS, Kemp AS Jones WR. Enhanced monocyte migration during thuman pregnancy. J Reprod Jimmunol 1980;2:37-44

5. Siegel I, Gleicher N. Peripheral white blood all alerations in early labor. Diagn Gynecol Obster $1981 ; 3: 123-6$

6. Grifin JF. Beck I. A longitudinal study of leucocyre numbers and mitogenesis during the last ten weeks of human pregnancy. J Reprod Immunol 1983:5:239-47

7. Yarndl JW, Swcetnam PM, Rogers S, Ewood PC. Baünon D, Baker IA, et al Some long rerm effects of smoking on the hatmostatic system: a report from the Cacphilly and Speedwell Collaborative. Surveys. JClin Parh 1987; 40:909-13

8. Crimm RH Jr, Nearon JD, Ludwig W. Prognoscic importance of the white blood cell count for Coronary cancer and all-cause mortality. AMA 1985:254: 1932-7

9. Phillips AN, Neatou JD, Cook DG, Grimm RH, Shaper AG. The leukocyte count and risk of lung cancer. Cancer 1992;69:680-4

10. Howell. RW. Smoking hathis and laborarory rests. Lance 1970;ii: 152

11. Corre F. Lellowch ], Shwarz. D. Snoking and leucocyte counts. Resulrs of an epidemiological survey. Lance 1971:ii:632-4

12. Friedman GD. Siegelaub AB, Seltzer CC. Feldman R, Collen MF. Smoking habiss and leukoone count. Arch Envion Heth 1973:26:137.43

13. Damm K. Damm A. Dona H. Distribution of mononudear cells in peripheral blood of fenales with spontancotis abortion. Zentralbl Gynakol 1991:113:935-42

14. Moncharmon P. Bonnard M. Bernatd J. Rigal D, Mellier G. Monier JC. Study of the immune profile of the pregnant women. I Gyneol Obster Biol Reprod Paris 1992,21:214-8

15. Merooff. Marermal leukacyte metabolism in fetal malnutrition. Adv Exp Med Biol 1974;49:73-118 
16. Tyengar LR, Vishwanathan MK. Leucocye metabolism in matemal and cord blood in intraurerine malnutrition. Int J Gynaecol Obstet 1983;21:217-21

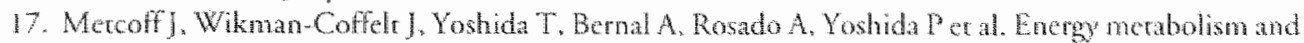
procen systhesis in human leucocytes during pregnancy and in placenta rated io fonl grown. Pediatrics 1973,51:866-77

18. Carbone P. Sobreviala M, Jimenez D, Marinez C. Conzalez-de-Aguero R, Pocovi M. Marernal leukocyte metabolism during pregnany and puerperium, and its relation we feal growh. Acra Obsret Gynaccol Scand 1992,71:266-72

19. Mercotf ], Yoshida T. Morales M, Rosado A. Urrusti ]. Sosa A. er al. Bionolecular srudies of fetal mal nuerition in maternal leukogres. Pediartics 1971:47 suppl 2:180.

20. Simpson W. A preliminary report on cigarere smoking and the incidence of premarurity. Am /Obsrer Gyrecol 1957:7-3:808-15

21. Bakketeg LS, Hofman HI, Oakley AR. Pernacal moraliry. In: Bracken MD, cdiror. Perinatal epidemiology. Oxford Universiry Press 1987,99-151.

22. Mellwaine GM, Howarr RC. Dunn F, Macnaughon MC. The Sconish perinatal moraliny surecy. BMJ 1979;ii:1103-6

23. Peacock JL, Bland JM, Anderson HR. Brooke OG. Cigareresmoking and birchweight: ype of cigarere smoked and a possible threshold effec. Inr J Epidemiol 1991:20:405-12

24. Rancakallio P. Retarionship of matemal smoking to morbidity and mortality of the child up ro the atge of five. Acra Pacdiarr Scand 1978;52:621-31

25. Sexron M. Fox NL, Hebel JR. Prenaral expostre to tobaco:ll. Effects on cognitive functioning at age three. Int Epidemiol 1990:19:72-7

26. Stjemfelde M, Berglund K. Lindsten J, Ludvigson J. Maternal smoking during pregnancy and risk of childhood cancer. Lance 1986;ii:1350-2

27. John EM, Savitz. DA, Sandler DP. Prenatal exposure to parents' smoking and childhood cancer. Am Epidemiol 1991:133:123\%32 

Chapter 5

\section{Erythrocyte count and indices during normal pregnancy of non-smoking and smoking} women

Patricia EAM Mercelina-Roumans ${ }^{1}$, JMH Ubachs', JWJ van Wersch ${ }^{2}$

From the Department of Obstetrics and Gynaecology 1 , and the Department of Haematology ${ }^{2}$, De Wever Hospital, Heerlen, The Netherlands. 


\section{Abstract}

In 247 nor-smoking and 123 smoking healthy pregnant women the erythrocyte count and indices were compared at fout different stages of pregnancy: $0-10,11-20,21-30$ and $31-40$ weeks. Exclusion criteria were a diastolic pressutre $\geq 90 \mathrm{mmH} H \mathrm{~g}$, an endocrine disease or a coagulation disorder. A wowen was considered a smoker if she smoked 4 or more cigarettes/day. Blood samples were ran on a Sysmex NE-8000.

The erychrocyte count wats significantly lower in smokers than in non-smokers $\left(3.86 \times 10^{12 / l}\right.$ wersus $\left.3.96 \times 10^{12} / 1\right)$ in the last ten weeks. Comparing the erythrocyte count during the beginning and the end of pregnancy there were significant lower values in bouth growps (4.32 $\times 10^{12 / 2}$ to $3.96 \times 10^{12 / l}$ in the non-smoking and $4.24 \times 10^{12 / l}$ to $3.86 \times 10^{12 / 1}$ in the smoking group). The differences in the median HGB and HCT levels were neglectable. The $M C V$ was significantly bigher in wownen who smoked, as was the MCH (MCV 91 fl and MCH 1.90 fmol in the non-snoking versus MCV 94 fl and MCH 1.95 froll in the smoking group in the las ten weeks.

Smoking in pregnancy leads to a lower erythrocyte count and a higher MCV ubich might create a bypoxic condition of the fetus.

Plasma volume and total red cell mass are under separate control and bear no fixed relation to each other. Changes in pregnancy provide an illustration of this point. Plasma volume rises progressively throughout pregnancy to a plateau in the last 8 weeks. "The increase in plasma volume is correlated with the birth weight of the baby. ${ }^{2}$ The red cell mass, which represents the total volume of red cells in the circulation, also rises during normal pregnancy. Because the increase in red cell mass during pregnancy is proporcionately less than the increase in plasma volume the concentration of red cells in the blood declines. The size and haemoglobin content of the cells show only minor changes; consequently the haemoglobin concentration and haematocrir fall parallel with rhe red cell count. Litrle has been reported on the effect of chronic cigarerte smoking on the erythrocyric system. It may decrease vitamin $B_{12}$ which could lead to an elevation of the mean corpuscular volume (MCV). ${ }^{3}$ Heavy long-term smoking may cause an erythrocytosis. ${ }^{4}$ Cigarette smoking is also associared with an entranced haemoglobin-CO concentration causing a mild form of hypoxia. The haemoglobin synthesis might also be impaired by the lead content of tobacco. ${ }^{6}$ Finally, smoking increases the plasma viscosity. ${ }^{7}$ Even less is known about the haematological consequences of cigarcte smoking in pregnancy. The aim of this study was to compare the erythrocyte count and the erythrocyte indices of smoking and non-smoking women at different stages of normal gestation. 


\section{Subjects and methods}

A rotal of 247 non-smoking and 123 smoking healthy pregnant women were included in this cross-sectional study. These women consecutively atrended the obsterrical department of the De Wever Hospiral, Heerlen. The Nerherlands berween november 1992 and april 1993. Exclusion criteria were a diastolic pressure $\geq 90 \mathrm{mmHg}$, an endocrine disease or a coagulation disorder. The duration of the gestation was based on the last menstrual date and an ultrasound derermination between 8 and 14 weeks. The number of cigaretres per day was an esrimation of the patient, in most cases confirmed by her partner. A women was considered a smoker if she smoked 4 or more cigarettes/day. The basic characteristics of these patients are given in Table 1.

Blood samples were drawn berween 8.30 and $9.30 \mathrm{am}$. into EDTA-K $K_{2}$ containing tubes (Sarstedr, Nümbrecht, Germany) and kept at room temperature for maximally 5 hours before they were run on a Sysmex NE-8000 (TOA Medical Electronics Corp., Kobe, Japan).

The significance of the differences of the median values of the various groups was assessed by the Mann-Whitney-Wilcoxon test.

\section{Results}

In Table 2 the erythrocyte count, the HGB concentration, the HCT values and the MCV and $\mathrm{MCH}$ values of the smoking and non-smoking group during the gestarional period are shown. Significantly lower values of the erythrocyte count were found in women who smoked during pregnancy. However, they did not start with a lower erythrocyte count, as the difference in the first ten weeks of pregnancy was not significant $\left(4.32 \times 10^{12} / /\right.$ in the non-smoking versus $4.24 \times 10^{12 / 1}$ in the smoking group).

Table 1. Basic characteriscies of the pregnant wonat

\begin{tabular}{|c|c|c|c|c|c|}
\hline Groups of parients & & Paricy & $\begin{array}{l}\text { Age } \\
(\text { years })^{\mathrm{a}}\end{array}$ & Iron medic & $\begin{array}{l}\text { Cigaretes } \\
\text { perday }\end{array}$ \\
\hline $\begin{array}{l}\text { Non-smokers. } \\
\text { normal pregnancy }\end{array}$ & $(n=247)$ & $\begin{array}{l}47.9 \% \text { primi } \\
52.1 \% \text { multi }\end{array}$ & $\begin{array}{l}30 \\
(27-33)\end{array}$ & $20 \%$ & 0 \\
\hline $\begin{array}{l}\text { Smokers. } \\
\text { nomd pregnancy }\end{array}$ & $(n=123)$ & $\begin{array}{l}47.8 \% \text { primi } \\
52.2 \% \text { multi }\end{array}$ & $\begin{array}{l}29 \\
(25-32)\end{array}$ & 170 & $\begin{array}{l}10 \\
(5-15)\end{array}$ \\
\hline
\end{tabular}

a values represent median (R). 
Table 2. Comparison of the erythroyte cours, the HCB concentration, the HCT walues, the MCV and MCH values of the snoking (S) and non-smoking (NS) fomales ar four stages during normal pregnancy

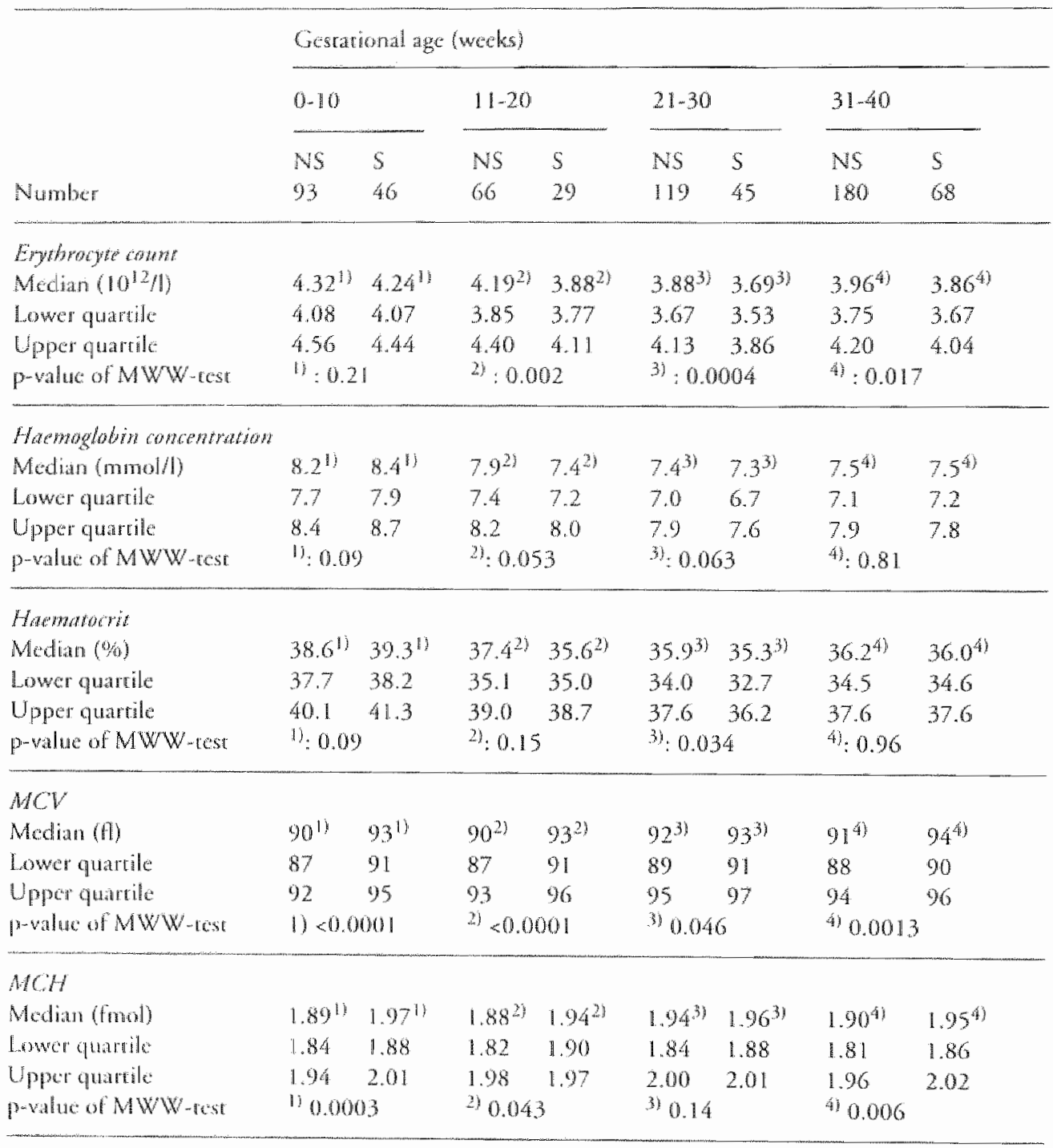

MWW = Mann-Whing-Wilcoxon-test; abbreviations are mentioned in text; $1-4$ represent the four stages of pregnincy. 
Tiable 3 . Surwey of the data on the pregnancy outcome of 123 smokers and 247 non-sinoticers

\begin{tabular}{|c|c|c|c|c|c|}
\hline Groups of patiencs & Frequency & $\begin{array}{l}\text { Birth weight } \\
(g)\end{array}$ & $\begin{array}{l}\text { Parandal weight } \\
\text { (g) }\end{array}$ & $\begin{array}{l}\text { Dluxus post } \\
\text { partumb (co) }\end{array}$ & $\begin{array}{l}\text { Thrombosis } \\
\text { post parmomb }\end{array}$ \\
\hline \multicolumn{6}{|l|}{ Nulliparous women } \\
\hline Non-smokers & 47.9 & $\begin{array}{l}3400 \\
(398)\end{array}$ & $\begin{array}{l}543 \\
(244)\end{array}$ & 4 & 0 \\
\hline Smokers & 47.8 & $\begin{array}{l}3119 \\
(534)\end{array}$ & $\begin{array}{l}506 \\
(128)\end{array}$ & 3 & 0 \\
\hline \multicolumn{6}{|l|}{ Parous women } \\
\hline Non-smolkers & 52.1 & $\begin{array}{l}3607 \\
(458)\end{array}$ & $\begin{array}{l}547 \\
(145)\end{array}$ & 4 & 0 \\
\hline Smokers & 52.2 & $\begin{array}{l}3340 \\
(553)\end{array}$ & $\begin{array}{l}565 \\
(192)\end{array}$ & 2 & 0 \\
\hline
\end{tabular}

a values reptesen mean (SD); b values represent incidence.

Comparing the erythrocyte count during the first and last 10 weeks of pregnancy there were significant lower values in both groups $\left(4.32 \times 10^{12 / 1}\right.$ to $3.96 \times 10^{12 / /}$ in the non-smoking and $4.24 \times 10^{12} / 1$ to $3.86 \times 10^{12} / 1$ in the smoking group). The Hb levels of the smoking group were lower throughout gestation, but the differences were not significant. The differences between the median HCT values of the smokers and non-smokers were neglectable. The MCV was significantly higher in smokers $(94 \mathrm{fl}$ versus $91 \mathrm{fl}$ in the last ten weeks). This also applies for the $\mathrm{MCH}(1.95$ fmol versus 1.90 fmol in the last ten weeks). Smokers started with higher MCV and MCH levels but these parameters did not rise further throughout pregnancy.

\section{Discussion}

In the group of chronic cigarette smokers the erythrocyte count during the gestarional period was lower and both the mean corpuscular volume and the mean corpuscular haemoglobin were higher. Moreover, there seemed to be a lower haemoglobin concentration in the women who smoked but that difference was not significant. The haematocrit level was not altered by smoking. Whether these haematological changes have an adverse effect on the course of the gestation and the growth of the fetus might be questioned. A lower erythrocyte count is equiva-lent with fewer oxygen transporting particles, which might create a hypoxic condirion for the fetus. Increased haemoglobin 
and hacnatocrit levels have been reported in newborns of smoking mothers. An explanation could be that maternal smoking creates a hypoxic condition for the fetus and thus srimulates erychropotesis.

Smoking thas been described to enhance blood viscosiry. In pregnancy whole blood viscosicy decreases significantly from an amenorhea of 16 weeks to 34 weeks, after which this tendency reverses. ${ }^{10}$ Pregmancics with intrauterine growth retardacion have been reported to have elevated whole blood viscosity compared with non-affected pregnancies." Nyland et al 12 found a significanty decreased utero-placental perfusion in women delivering a growh-retarded child. Maternal blood viscosity might influence fetal growth by affecting placental perfusion on the maternal side. 13 An enhancement of the blood viscosity provokes a reduction of the MCV. However, in the patients who smoked there was an elevarion of the MCV. A lower maternal erythrocyte count and higher maternal MCV is not a favourable combination for the fertis. The production of $\mathrm{PGI}_{2}$ in the umbilical cond is decreased by smoking which causes a constriction of the vessels in the placenta. A lower erythrocyte count means less oxygen transport whereas the ransport of larger erythrocytes is more difficul in constricted vessels. The haemoglobin concentration was decreased in pregnant women who smoked. High maternal haemoglobin levels, reflecring a comparatively decreased plasma volume, have been associated with uterine fetal dearh. ${ }^{4-17}$ On the opposite, low maternal haemoglobin levels have been found in mothers with large newborns. 18 In our study group, neonates and placentas of (nulli) parous smokers weighed significantly less than neonates and placentas of non-smokers (Table 3).

In conclusion, smoking in pregnancy leads to a lower erythrocyte count and a higher MCV. Alrhough we are aware that the shifts remain within the reference range, these findings might creare a slightly hypoxic condition for the fetus. Further investigation has to be done on the erychrocyte count and indices in umbilical cord blood to assess the relevance of these data for newborns who have been exposed ro maternal smoking compared to those who have not been exposed.

\section{References}

1. Pirani BB, Camplell OM. MacCilliveny I. Plasma volume in normal first pregnancy. J Obstet Gynaecol Br Commonw $1973,80: 8847$

2. Hytern $\mathrm{FE}$, Leirch $\mathrm{I}$. The volume and composition of the blood. The physiology of human pregnancy. and ed. Oxfond: Blackwall, $1971: 1$

3. Jones PD. Hutson N. Hawkey CJ. Depression of salivary epidemal growth factor by smoking. BM] $1992 ; 304: 480-1$

4. Smith IR, Landaw SA. Smokers polycythemia. N Engl J Med 1978;208:6-10

5. Townsond J. Wilkes H. Haines A Jarvis M. Adolescene smokers seen in general practice. heallh. lifestyle, physical measurements, and response to antismoking advice. BMJ 1991;303:947-50

6. Boyet JD, Butterworth CE J. Lead poisoning and hemoglobin synthesis. Am J Med 1962;32:884 
7. Fore MC. Cigarere smoking: a dinical gude to assesment and treatment. Mod Oin North Mm 1992,76:289-539

8. Garn SM, Shaw HA, McCabe KD. Effect of matemal smoking on hemoglobins and hamatocrits of the newborn. Am J Clin Nurr 1.978;31:557-8

9. Belch 1]. McArdle BM, Burns P, Lowe GD. Forbes CD. The effecs of acute smoking on plaxelen behaviour, fibrinolysis and hacmorheology in habituat smokers. Thromb Hacmost 1984:51:6-8

10. Buchan PC, Mac Donald HN, GDO Lowe, JC Barlyennel and CD Forbes, eds. Rheological studics in obserrics and gynecology. Clinical aspects of blood viscosity and cell deformatilin. Berlin: Springer-Verlag, $175-192$.

11. Heilmann L. Matheck C. Kury. E. Rheologische Verinderungen des Blutes in der normalen und partologischen Schwangerschaft und deren Einfuss auf die Sauerstoffdifusion. Arch Gynakol 1977:223:283-98

12. Nylund L, Lunell NO, Lewander R, Sarby B. Uteroplaceneal blood How index in incrauterine growth retardation of fetal or matemal origin. Br J Obster Gynaecol 1983:90:16-20

13. Zonderwan HA, Voorhorst F, Roberson EA, Kurver PH, Massen C. Is matemal whole blood viscosiry a factor in fetal growth? Eur J Obstet Gynecol reprod Biol 1985;20:145-51

14. Dunlop W, Furness C. Hill L.M. Matemal hacmoglobin concentration, hacmatocrir and renal handling of urate in pregnancies ending in the births of small-for-dates infants. Brit I Obster Gynacol $1978,85: 938-40$

15. Koller $O$, Sagen N, Ulstein M, Vaula D. Feral groweh retardarion associated with inadequate haemodilution in otherwise uncomplicated pregnancy. Acta Obster Gyncol Scand 1979;58:9-13

16. Koller 0 , Sandwei R, Sagen N. High hemoglobin levels during pregnancy and feral risk. Ind I Gonacol Obster 1980;18:53-6

17. Mau G. Hemoglobin changes during pregnancy and growith disturbances in the neanate. I Perinat Med 1977;5:172-7

18. Beischer N.A. Holsman M, Kirchen WH. Relarion of warious forms of ancmia ro placental weight. Am J Obster Gynecol 1968:101:801-9 

Chapter 6

\section{The reticulocyte count and its subfractions in smoking and non-smoking pregnant women}

Patricia EAM Mercelina-Roumans', JMH Ubacbs', JWJ van Wersch ${ }^{2}$

From the Department of Obstetrics and Gynaecology', and the Department of Haematology ${ }^{2}$, De Wever Hospital, Heerlen. The Netherlands. 


\section{Abstract}

Our obgective was to compare the reticulocye count and its subfoctions in smobing and non-smoking wowen at different stages of nomal pregnang. The reticulocyte count and ats subfrations were compared in 247 non-smoking and 123 smoking healiby pregnant wowe at four differentstages of pregnancy: 0-10,11-20,21-30 and 31-40 wets. Exclusion criteria were a diastolic pressure $\geq 90$ mmHg, an endacrine disease ar a coagulation disorder. Women in the smokers group snoked more than 4 cigarewes/day. Non-smokers were defined as women reporting wo smoking at all. Bloodsamples were nn on a Sysmex R-3000 reticulocyte counter. The absalute reticulacte count was lower in the smoking group thowghout pregnancy, but this was only significant in the last ten week of gestation $\left(71.9 \times 10^{\circ} / \mathrm{l}\right.$ werws $78.8 \times 10^{\circ} \mathrm{hl}$ ). There was wo differewe between the low fuorescence, the medium fuorescence and the bigh fuorescence proportions in the non-smoking and the smoking growp. Both groups behaved similarly during pregnanoy; there was a decrease of mature reticulocyes and a significant increase of more inmatume reticulocytes.

These data show a moderate measurable effect of cigarete smoking on the reticulocyte count and the absence of an effect on the reticulocyte subsets.

Reviculocyte couning allows the direct measurement of the activity of erythropoiesis in the bone marrow. Manual reticulocyte counting has been reported as problematic. ${ }^{1-5}$ To improve the reliability of reticulocyte counting, several automated methods and instruments have been inroduced. ${ }^{6-8}$ The Sysmex R-3000 was used in this study. This instrument is able to provide precise and statistically reliable reticulocyte counts. Furthermore, it estimates the maturity of a reticulocyte by measuring the fluorescence intensity, a reflection of the RNA content of the cell. Castriota et al ${ }^{10}$ studied the total rericulocyce count and the reticulocyte fluorescence intensity ratios in a nomal pacdiatric population. They found that the reticulocyte subsets allow a more accurate evaluation of bone marrow activity than the total reticulocyte count.

The reticulocyte population an be divided into three groups. They are defined by ravios of the rotat Auorescence intensity and termed low, medium and high fluorescence matios. "As the reticulocytes become older, their fuorescence (RNA content) decreases. The high fuorescence ratio is therefore a reflection of the most immature reticulocyte. These phenomena have not been inwestigated in pregnanc women. The aim of this study was to compare these quantiries in smoking and non-smoking females during a normal pregnanoy.

\section{Subjects and methods}

Two hundred and fory-seven non-smoking and 123 smoking healthy pregnant women were included in the srudy. These women consecutively artended the obstetrical depart- 
ment of the De Wever Hospital, Heerlen, The Netherlands beween november 1992 and april 1993 . The reticulocyte count and subsers were determined at four different stages (0-10,11-20,21-30,31-40 weeks) of pregnancy. Not all patients were checked in all four stages. Exclusion criteria were a diastolic pressure $\geq 90 \mathrm{mmHg}$, an endocrine disease or a coagulation disorder. The duration of the gestation was based on the last menstrual period and an ultrasound deremination berween 8 and 14 weeks. The number of cigarettes smoked per day was an estimation of the parient, in most cases confirmed by her parner. If a women smoked more rhan 4 cigaretres/day she was called a smoker. The group of women who smoked more than 15 igarertes/day was too small ro subdivide the smokers into an intermediate smoking level group (5-15 cigarertes per day) and a group of heavy smokers ( $>15$ cigarettes per day). Non-smokers were defined as women reporting no smoking at all. The basic characteristics of these parients are given in Table 1.

Venous blood samples were collected in EDTA-K2 containing tubes (Sarstedt. Nümbrecht, Germany). Samples were kept at room temperature until analysis. The measurements were performed with the relatively new Sysmex R-3000 reticulocyte counter ( $T$ oa Medical Electronics, Kobe, Japan). The coefficients of the interassay variation for the reticulocyte count amounted $6.7 \%$ and $7.6 \%$ at levels of $14 \times 10^{\%} / 1$ and $36 \times 10^{\circ} / 1$ respectively (reference range for women $20-110 \times 10 \% / 1$ ). This instrument provides the reticulocyte count as a percentage of the erythrocytes, the absolute reticulocyte count, the red blood cell count and the platelet count as well as a cytogram from which the reticulocytes can be subdivided into low, medium and high fluorescence rario reticulocytes, in that order indicaring three stages in the maturation of the reticulocytes. "The significance of the differences of the median values of the various groups was assessed by the Mann-Whitney- Wilcoxon test.

Table 1. Basic characteristics of the pregnam women

\begin{tabular}{|c|c|c|c|c|}
\hline Groups of pacients & $\begin{array}{l}\text { Age } \\
\text { (ycars) }\end{array}$ & $\begin{array}{l}\text { Iron } \\
\text { medication }\end{array}$ & Pariyg & Cigaretes per day \\
\hline $\begin{array}{l}\text { Non-smotkers, } \\
\text { nomal pregnancy }(n=247)\end{array}$ & $\begin{array}{l}30 \\
(27-33)\end{array}$ & $20 \%$ & $\begin{array}{l}47.90 \% \text { primai } \\
52.106 \text { muhi }\end{array}$ & 0 \\
\hline $\begin{array}{l}\text { Simokers, } \\
\text { nomal pregnancy }(n=123)\end{array}$ & $\begin{array}{l}29 \\
(25-32)\end{array}$ & $17 \%$ & $\begin{array}{l}47.8 \% \text { primi } \\
52.2 \% \mathrm{mulni}\end{array}$ & $\begin{array}{l}10 \\
(5-15)\end{array}$ \\
\hline
\end{tabular}

Malues represent median (IR). 


\section{Results}

Figure 1 gives a compatison of the median values of the absolute reticulacyte count of smoking and non-5moking females in four stages of pregnancy.

The retululocyte count throughout pregnancy was lower in the smoking group but this was only significant in the $31-40^{\text {th }}$ week of gestation $\left(71.9 \times 10^{9} / 1\right.$ versus $78.8 \times 10^{\circ} / 1$; $0<0.014)$.

The median low, medium and high fluorescence ratio percentages did not differ significantly beween the two groups. The three reticulocyte subfractions behaved similaty in both groups. The low fluorescence ratio decreased (from 88.5 to $78.6 \%$ in the non-smoking, from 88.3 to $77.4 \%$ in the smoking group), whereas the medium furescence vatio (from 10.7 to $18.0 \%$ in the non-smoking, from 10.8 to $17.4 \%$ in the smoking group) and the high fluorescence ratio (from 1.0 to $3.6 \%$ in the non-smoking, from 1.1 to $4.4 \%$ in the smoking group) increased significantly from the beginning ro the end of gestation.

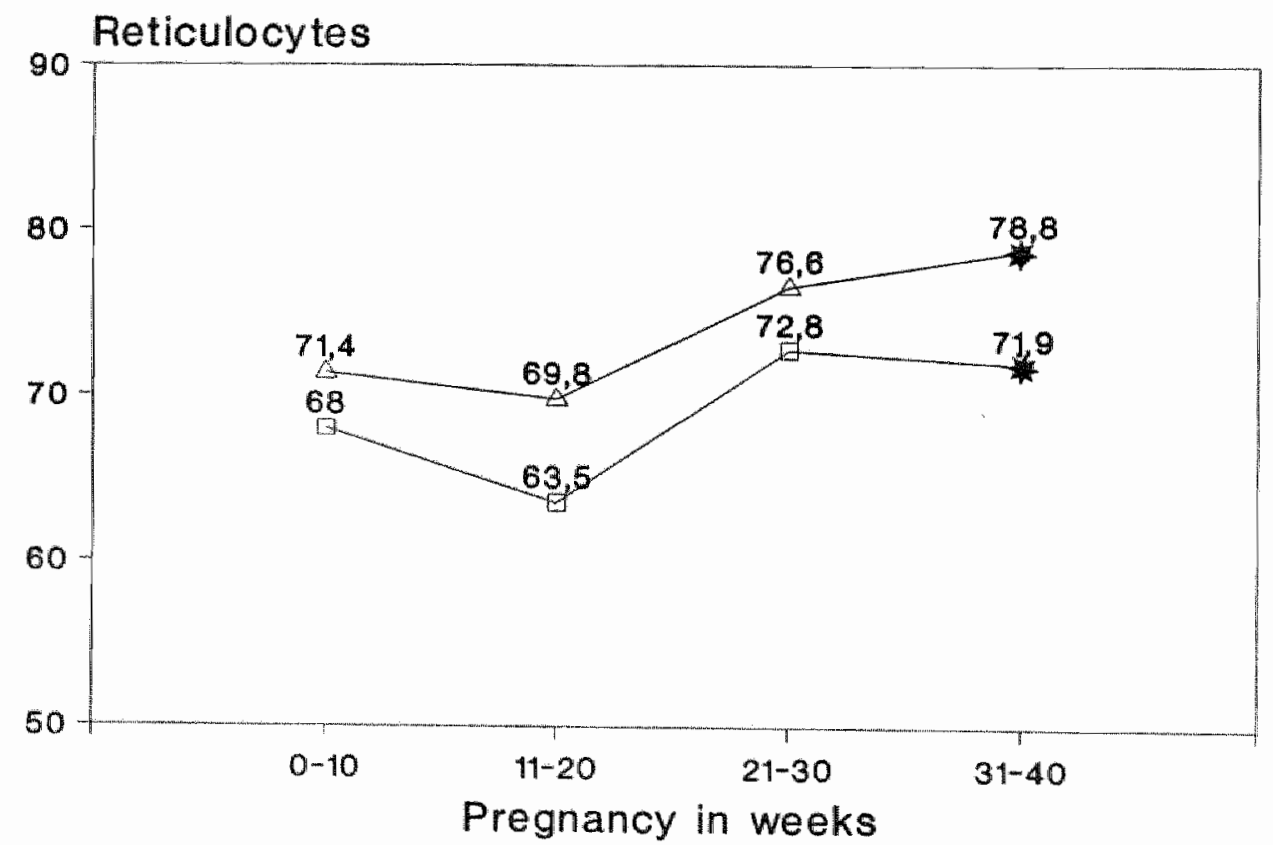

Fig 1. Comparison of the absolute values of the rericulocyte counc of the smoking (D) and non-smoking

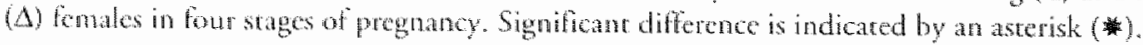




\section{Discussion}

The erythrocyte count and indices in smoking and non-smoking pregnant women were studied earlier. ${ }^{12}$ Smoking pregnant women appeared to have lower erythrocyte counts from the $11^{\text {th }}$ week of gestation onwards. An increase of bone marrow activity and a consequenc increase of reticulocytes was to be expected in the same period. In the present study however, smoking pregnant women had a lower reticulocyte count in the last ten weeks of pregnancy, suggesting an absence of increased bone marrow activity. The reticulocyte subsets did however show a significant increase of bone marrow activity, both in non-smoking and in smoking pregnants. The low fluorescence ratio, indicaring the more marure reticulocytes, decreased, whereas the medium and high fluorescence ratios, representing the more immature reticulocytes, increased significantly from the beginning to the end of gestation. The relative stability of the reticulocytes and the steady increase of the reticulocyte subsers suggest a rapid decrease of the intramerythrocytic RNA content in the course of the reticulocyte maturation during pregnancy. This process seems to be independent wherher or not the pregnant woman smokes. The latter is remarkable as one would expect a counterregulation of erythropoiesis as a reacrion to the decline of erythrocytes due to smoking in pregnancy.

Cigarette smoke may have an effect on the bone marrow and thus affect erythropoiesis. German ${ }^{13}$ found an inhibition of erythropoiesis: in individuals who smoked less than five years the reticulocyte maturation rate was reduced, as was the level of circulating red cells. Controversially, the erythropoiesis was normalized in those subjects who smoked more than five years. The author stated that these findings reflect different phases of the toxic effects of tobacco smoke on the bone marrow.

However, cigaretre smoke may also have a direct effect on the eryrhrocyte itself. The same investigator found a toxic effect on the red cell. Six to ten years of smoking resulted in toxic lesions of the circulating erythrocytes confirmed by an increase of the number of spherulation altered cells, early onser and a late termination of haemolysis and an increase of the percentage of perished cells. ${ }^{14}$ The biological mechanism is unclear.

\section{Conclusion}

The measurable effect of cigaretre smoking on the reticulocyte count was moderate, whereas the effecr on the low, medium and high fluorescence proportions was absent. These results indicate that no real counterregulation occurs as a reaction ro the decline of erythrocyres due to smoking in pregnancy. The mechanisms by which smoking affects the bone marrow or the erythrocyre itself remains undear. 


\section{References}

1. Dess $A$, Kurth $D$. Circulating reviculocytes in normal adulis as derermined by the new methylene blue merhod. An J Cin Parhol 1970;53:481-4

2. Gimer PR Jr. Koepke JA. The renculecyte. An approach wo definition. An J Clin Pathol 1976;66:262-7

3. Creenberg ER, Beck JR. The effecs of sample size on reciculocyte counting and stool examination. The binomial and poisson-distriburions in laboracory medicine. Arch Pathol Lab Med 1984;108:396-8

4. May JA, Sage BH. Spiner films for rericulocyte counts. Am J Med Technol 1976:42:357-60

5. Peebles DA. Hochberg A, Clarke TD. Analysis of manual reticulocyte counting. Am J Clin Pathol $1981,76: 713-7$

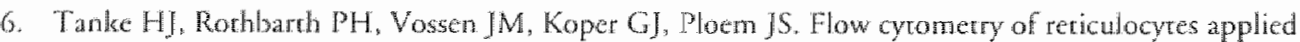
to dinical hematology. Blood 1983:61:1091-7

7. Tatsumi N. Tsuda I, Kojima K, Niri M, Setoguchi K. An auromated reviculocyte counting method: preliminary observations. Med Lab Soi 1989;46:157-60

8. Vaughan WP, Hall J, Johnson K. Doughercy C, Peebles D. Simultaneous reticulocyte and plarelet counting on a clinical flow cytometer. Am J Hematol 1985:18:385-91

9. Shoustal AM. Evaluation of the Sysmex R-3000 automated reticulocyte analyzer with comparison to the Symex R-1000. Sysmex Int J 1992;2:16-25

10. Castrota-Scanderbeg A. Pedrazz G, Mercadant M, Stapane I, Butmini A, Izxi G. Normal values of rotal reticulocyes and reticulocyre subses in children and young aduls. Haematologica 1992,77:363-4

11. Sato K, Kimuna T, Shigera S, Koyanagi $Y$, Hiroko $H$, Sugawara $K$. The dinical usefulness of rericulocyte classification by fluorescence incensity. Sysmex Int J 1991:14:29-35

12. Mercelina-Rommans PE, Ubachs JM, wan Werch JW. Erythrocyte count and indices during nomal pregnancy of non-smoking and smoking women. Eur J Obst Gynecol Reprod Biol 1994;57:25-8

13. Geman AK. The effec of smoking on the composition of the peripheral blood in normal subjects. Lab-Delo 1991:42-5

14. German AK. The erythrocyte composition of the peripheral blood in tobacco smokers. Vrach-Delo 1992 J U1 $(7): 40-2$ 
Chapter 7

\section{Platelet count and platelet indices at various stages of normal pregnancy in smoking and non-smoking women}

Patricia EAM Mercelina-Roumans', JMH Ubachs', JWJ wan Wersch ${ }^{2}$

From the Department of Obstetrics and Gynaecology ${ }^{1}$, and the Department of Haematolog $y^{2}$, De Wever Hospital, Heerlen. The Netherlands. 


\section{Abstract}

Our objective was to compane the platelet count and platelet indices of smaking and non-swoking wowen at different stages of nownal pregnancy. In 247 non-moking and 123 moking bealthy pregnant women the platelet count, the mean platelet volume the platelet distribution widh and the plateletrit were compared at 0-10,11-20,21-30 and 31-40 wetes of pregnancy. Exthsion criteria were a diastolic pressure $\geq 90 \mathrm{mmHg}$ an endocrine disease, a coagulation disorder, acetylalicylic acid or phemprocoumon we. A women was considered a smoker if she smaked more than 4 cigarettes a day. Non-smokers were defined as women reporting no smoking at all. Blood samples were run on a Sysmex NE-8000. There was wo significant differewce between the platelet cownt in the two groups. In the won-smoking growp, the platelet cownt showed a significant decrease with gestational age (287 $\times 10^{9} / 1$ to $\left.258 \times 10^{9} / 1\right)$. This was wot the case in the smokers aroup. The mean platelet wolume of the smokers was significanty lower wan that of the non-smokess in the last ten weeks of pregnancy (10.4 $\mathrm{f}$ versus $10.7 \mathrm{fl}$ ). The platele distribution width and the plateletcrit did not change under the infuchace of cigarette smoking.

Smoking during pregnancy does not affect platelet cownt or platelet indices.

In recent years there has been a broad interest in defining the mechanisms responsible for the adverse effects of cigarette smoking. ${ }^{1-3}$ Various reports have focused on the influence of smoking on platelers because of a possible association between smoking, an alteration of blood platelets and atherosclerosis. $4-7$ Some of these studies showed an increase of platelet turnover and a decrease of platelet survival in smokers. ${ }^{4,7}$ The increased destruction of platelets, however, was not sufficient to reduce the number of circularing platelets. Platelet counts either remained normal ${ }^{4,8}$ or were increased. 9,10 Smoking and platelet behaviour during pregnancy were not addressed up to now. Most platelet studies have been confined to platelet counes in normal pregnancy regardless of the smoking behaviour of the women, although the combinarion of plateler and plateler sine parameters as mean platelet wolume (MPV), platelet discribution width (PDW) and plarelercrit (PCT) mighe provide berter insight in platelet biology during pregnancy. The aim of this sudy was to assess the platelet count and plateler indices at various stages of normal pregnancy in smoking and non-smoking women.

\section{Subjects and methods}

Two huadred and forty seven non-smoking and 123 smoking healthy pregnant women conscutively attending rhe obsterical department of the De Wever Hospital, Heerlen, The Netherlands between november 1992 and april 1993 for monitoring of their pregnancy, were included in the study. The platelet count and platelet indices were deremined at four diferent stages $(0-10,11-20,21-30,31-40$ weeks) of pregnancy. 
Not all patients were checked in all four stages. Exclusion critera were a diastolic pressure $\geq 90 \mathrm{mmHg}$, an endocrine disease or a coagulation disorder. None of the partents used acecylsalicylic acid or phenprocoumon. The known duration of the gestation was based on the last menstrual period and an ulrasound determination between 8 and 14 weeks. The number of cigaretres smoked per day was estimated by the parient, in most cases confirmed by her parner. A women was considered a smoker if she smoked more chan 4 cigaretres a day. The group of women who smoked more dhan 15 cigaretres a day was too small to subdivide the smokers into an intermediate smoking level group $(5-15$ cigarettes per day) and a group of heavy smokers ( $>15$ cigarettes per day). Non-smokers were defined as women reporting no smoking at all. The basic characteristics of nhese parienrs are given in Table 1.

Blood samples were drawn berween 8.30 and 9.30 a m. into EDTA-K 2 containing rubes (Sarstedt, Nümbrech, Germany) and kept at room temperature for at most 5 hours before they were run on the Sysmex NE-8000 (TOA Medical Electronics Corp " Kobe, Japan). The inter-assay coefficients of variation amounted for the platelet count $5.9 \%$ at $259 \times 10^{\%} / 1$ (assigned value $253 \times 10^{\%} / 1$ ), for the mean plateler volume $1.8 \%$ ar 8.81 (assigned value $8.4 \mathrm{f}$ ), for the platelet distribution widn $2.8 \%$ at $9.5 \%$ and for the plateletcrit $18 \times 10^{-4} \mathrm{~J} / \mathrm{l}$ at $22 \times 10^{-4} \mathrm{l} / \mathrm{l}$.

The significance of the differences of the median values of the various groups was assessed by the Mann-Whimey-Wilcoxon test.

\section{Results}

In Table 2 the comparison of the platelet counts of the smoking and non-smoking females at four stages of pregnancy is given. In the non-smoking group the platelet count showed a slight but significan decrease with gestational age. The group stated with a median platelet count of $287 \times 10^{9} / 1$ and ended with a platelet count of $258 \times 10^{9} / 1(p=$ $0.002)$. The decrease from $283 \times 10^{9} / 1$ to $264 \times 10^{\%} / \mathrm{l}$ in the smokers group however was not significant $(p=0.86)$.

The MPV of the smokers was significanty lower than the volume of the non-smokers in the last ten weeks of pregnancy $(10.4$ versus $10.7 ; \mathrm{p}=0.02)$. The MPV in the non-smoking group did not change during gestarion. This quantiry was also more or less stable in the smoking group. The PDW of the two groups was compared and did not change under the influence of smoking. There was also no difference in the plateletcrit values. In the non-smoking group the PDW increased signilicantly from the beginning to the end of pregnancy $(11.7 \%$ to $12.3 \% ; \mathrm{p}=0.03)$. This was not the case in the smoking group. The PCT in the non-smokers decreased significanty throughout pregnancy $\left(26.3 \times 10^{-4} \mathrm{l} / 1\right.$ to $\left.24.9 \times 10^{-4} \mathrm{l} / \mathrm{l} ; \mathrm{p}=0.04\right)$. The PCT in the smokers also decreased throughour pregnancy, but this difference was not significant. 


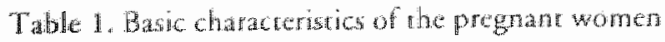

\begin{tabular}{|c|c|c|c|}
\hline Croups of pations & $\begin{array}{l}\text { Age } \\
(y \in a r s)\end{array}$ & Purly & Cigaretres per day \\
\hline
\end{tabular}

Non-mokers.

nom mal pregnancy $(n=247)$

30

$(27-33)$

$47.9 \%$ primi

0

$52.1 \%$ mulri

Smokers,

normal pregnancy $(n=123)$

$47.8 \%$ primi

10

$(25-32)$

$52.2 \%$ mulli:

$(5-15)$

Values represcon median (IR).

Table 2. Companson of the placeler counrs of the smoking (S) and non-smoking (NS) females at fou scages during normal pregnancy

\begin{tabular}{|c|c|c|c|c|c|c|c|c|}
\hline \multirow{3}{*}{$\begin{array}{l}\text { Gestatiomal age (woeks) } \\
\text { Patient groups }\end{array}$} & \multicolumn{8}{|c|}{ PLATELETS } \\
\hline & \multicolumn{2}{|l|}{$0-10$} & \multicolumn{2}{|l|}{$11-20$} & \multicolumn{2}{|c|}{$21-30$} & \multicolumn{2}{|l|}{$31-40$} \\
\hline & NS & $s$ & NS & $S$ & NS & S & $\mathrm{NS}$ & 5 \\
\hline Sanaple size & 93 & 46 & 66 & 29 & 119 & 45 & 180 & 68 \\
\hline $\operatorname{Modian}\left(10^{9} / 1\right)$ & $287^{11}$ & $283^{1}$ & 264 & $267^{27}$ & $264^{3}$ & $283^{33}$ & $258^{4 !}$ & $\left.264^{4}\right)$ \\
\hline Lower quartile & 232 & 215 & 230 & 239 & 226 & 247 & 211 & 232 \\
\hline Upper quartile & 325 & 322 & 302 & 299 & 308 & 334 & 302 & 312 \\
\hline$p=$ wallac of MWW-mest & \multicolumn{2}{|c|}{ n.s. } & \multicolumn{2}{|c|}{$n . s$} & \multicolumn{2}{|c|}{ nos. } & \multicolumn{2}{|c|}{ n.s. } \\
\hline
\end{tabular}

$M W W=$ Mann-Whitucy-Wilcoxon-tess; ${ }^{1.4}$ epresent the four stages of pregnancy.

\section{Discussion}

In the present study the only difference in platelet counts observed was a slight but significant decrease with gestational age in the non-smoking group. Plateler survival is known to be diminished in lare pregnancy. "This is due to an accelerated state of coagulation and fibrinolysis which increases towards term. ${ }^{12}$ Haemodilution in pregnancy may be another explanarion for the decrease of platelets. ${ }^{13}$ It is remarkable that this decrease of platelets does not occur in the smoking group. 
Most plareler studies in normal pregnancy have been confined to platelet counts, but the platelet count alone is not conclusive. Platelet size indices provide more information about platelet biology. The MPV is an indication of the amoun of young platelets. Fay et allit studied platelet count and indices in blood samples from 2066 healthy women with an uncomplicated pregnancy. The MPV remained stable until 35 weeks gestarion and rose dramatically thereafter. Ahmed et al ${ }^{15}$ studied the MPV in healthy pregnant women. This quantity remained constant berween the first trimester and the end of normal pregnancy. In patients who became pre-edamptic a persistent increase in MPV was found. Hutt et al ${ }^{16}$ found that the mean placelet volume increased 2-3 weeks before the development of pre-eclampsia.

In our srudy the MPV was significantly lower in the last ten weeks of pregnancy in the smoking than in the non-smoking group. The MPV of the non-smokers remained almost constant from the beginning to the end of pregnancy.

Less has been published regarding PDW and PCT in pregnancy. In the present sudy these indices remained more or less constant in both smoking and non-smoking women throughout pregnancy. This is in accordance with earlier results of our group ${ }^{17}$, when platelet indices were srudied in normal pregnancy.

In several studies the effect of the tobacco smoke constituents nicotine and carbon monoxide on plareler aggregation in non-pregnant women has been evaluated in vivo and in vitro. 18-21. They generally showed evidence of platelet activation. Smokers had an enhanced aggregation of platelets, although the platelet count did not differ from non-smokers. The present study indicates that smoking during pregnancy does not affect platelet count and platelet indices in a clinically relevant way.

However, the effect of the combination of smoking and pregnancy on platelet aggregation srill has to be assessed.

\section{References}

1. Kannel WB. Update on the role of cigarence smoking in coronary artery discast: Am Hart J $1981 ; 101: 3.19-28$

2. Friedman GD, Periti DB, Bawol RD, Siegclaub AB. Mortality in cigarcuc smokers and quiters. N Engl I Med 1981:304:1407:10

3. Billimoria JD, Pozner H, Merselar B, Best FW, James DC. Effece of cigarecte smoking on lipids. lipoproteins, blood coagulation, filvrinolysis and cellular components of haman biond. Arherosclerosis $1975,21: 61-76$

4. Musard JF, Murplyy EA. Efect of smoking on blood coagularion and platelet surwixal in man. Br. Med J $1963 ; 1: 846-9$

5. Hawkins RI. Smoking, platelcs and thrombosis. Nature $1972 ; 236: 450-2$

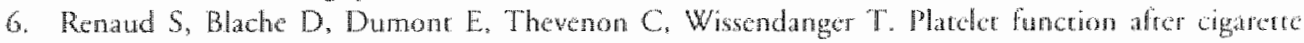
snoking in relation to nicotine and cartwon monoxide. Clin Pharmacol Ther $1984,36,389-45$ 
7. Fuster $V$, Chesebro JH, Frye RL, Eveback LR. Plareler survial and the developmen of coronary artery discase in the young adule effects of cigarene smoking, strong family history and medical therapy. Circulation $198: 635460.51$

8. Ring T, Krisensen SD, Jensen P. Mourts-Andersen T. Madsen H. Dyerberg J. Cigaretre smoking shorens the bleding tume. Thromb Res 1983:32.531-6

9. Murchison LE, Fyfe T. Effeces of cigarete smoking on serum-lipids. blood-glucose and plarelet adhesiveness. Lancet $1966 ; 2: 1824$

10. Erikssen 1. Hellem A, Sromorken H. Chrone effect of smoking on platele count and "platelet adhesiveness" in presumably hearty middle-aged men. Thromb Haemost 1977;38: 606-11

11. Wallcnburg HC, wan Kessel PH. Platele life span in normal pregnancy as detemined by a nonradiósowpic technique. Br J Obster Gynaecol 1978:85:33-6

12. MoKay DG. Chronic intravascular coagulation in nomal pregnancy and pre-echampsia. Conrrib Nophrol 1981:25:108-19

13. Letsky $\mathrm{E}$. The haemarological system. In: Hycten $\mathrm{F}$, Chamberlain $\mathrm{G}$, edirors Chinical physiology in Obstenics. 2nd ed. Oxford: Blackwetl Scientific, $1991: 39-82$

14. Way RA, Hughes AO. Farron NT. Plarelers in pregnancy: hyperdestruction in pregnancy. Obset Gyncol $1933,61: 238-40$

15. Ahmed Y, van Iddekinge B. Paul C, Sullwan HF, Elder MG. Retrospecrive analysis of platelet numbers and volumes in nomal pregnancy and in pre-edampsia. Br. J Obstet Gyaecol 1993;100:216-20

16. Hurt $\mathrm{R}, \mathrm{Ogumiyi}$ SO, Sullivan $\mathrm{MH}$. Elder $\mathrm{MG}$. Increased plateler volume and aggregarion precede the onser of precdampsia. Obster Gynecol 1994;83:146-9

17. Van Werch IW, van Hof $A C$, Ubachs IM. The use of an impedance particle counter for the measuremexu of platclet coum, plateler indices and platelet funcrion during pregnancy. Sysmex Int I $1992,2: 44-9$

18. Berghond U, Wallentin L, von Schenck H. Platele function and plasma fibrinogen and their relarions to gendar, smoking habits, obesicy and betablocker treatmene in young survivors of myocardial infaction. Thromb Hacmost $1988 ; 60: 21-4$

19. Dotevall $A$, Kurri J, Teger-Nisson, Wadenvik $H$, Wilhemsen L. Plateler reactivity, fibrinogen and smoking. Eur J Hacmatol 1987;38:55-9

20. Lasklo E, Kaldi N, Kovacs L. Alterations in plasma proteins and platelet functions with aging and cigarete smoking in healchy man. Thromb Haemosk 1983:49:150

21. Beth Jl MeAdilc BM, Burns P. Lowe GD, Forbes CD. The affect of acute smoking on platelet behaviour, fitrinolysis and hacmontheology in habirual smokers. Thromb Hacmose 1984:51:6-8 


\section{Chapter 8}

\section{Coagulation and fibrinolysis in smoking and non-smoking pregnant women}

Patricia EAM Mercelina-Roumans" JMH Ubachs" , JWJ wan Werch ${ }^{2}$

From the Department of Obstetrics and Gynaecology" and the Department of Haematology ${ }^{2}$, De Wever Haspital, Heerlen. The Netherlands. 


\section{Abstract}

The objective of the sudy was to assess the effects of smoking during pregnancy on coagulation and fibrinolysis. Forty-four non-smoking and 57 smoking pregnant wowen were included in whe siudy. Prothrombin fragment $1+2$ and TAT levels were assessed to monitor coagulation activation. Plasminogen, $\alpha_{2}$-antiplasmin and $D$-dimer levels were determined in order to measure the fibrinolytic activity.

Patrameters of coagulation activation increased significantly with gestational age. Prothrombin fragment $1+2$ increased from 0.8 mmolll to 2.5 nmolll in the non-smoking group of pregnant women and from 1.0 nmoll to 1.8 mmoll in the smoking growp. Thrombinantithrombin 171 levels increased from $2.2 \mu \mathrm{g} / \mathrm{l}$ to $9.9 \mu \mathrm{g} / \mathrm{l}$ in the non-smoking graup and from $3.1 \mu \mathrm{g} / \mathrm{l}$ to $8.5 \mu \mathrm{g} / \mathrm{l}$ in the smoking group. Parameters of fibrinolysis showed a different pucture. Plasminogen levels in bath groups rose significantly in the first half of gestation reaching a plateau in the second half. The $\alpha_{2}$-antiplasmin levels remained constant in both groups, althougly the smokers started with significantly bigher levels: $119 \%$ versus $105 \%$ in the non-smokers. The D-dimer levels rose significantly in both groups: from $278 \mu \mathrm{g} / \mathrm{m} / \mathrm{t}$ to $847 \mu \mathrm{g} / \mathrm{ml}$ in the non-smokers and from $215 \mu \mathrm{g} / \mathrm{ml}$ to $520 \mu \mathrm{g} / \mathrm{ml}$ in the smokers. They were significantly lower in the smoking group from the $11^{\text {th }}$ up to the $40^{\text {th }}$ week. The Ddimer/TAT ratio was significantly bigher in the nan-smokers.

In smoking pregnant women the activated coagulation process was not counterbalanced by an adequate increase of fibrinolysis which was the case in the non-smokers.

Coagulation is activated in response to rupture of a vessel or damage to special activator substances in the blood. A complex of substances called prothrombin activator is formed through two different pathways (Fig. 1). The exurinsic pathway (factor VII) begins with trauma of the vascular wall or rissue and the intrinsic parhway (factor XII, XI, IX, VIII) starts in the blood itself. In both parhways various plasma proteins play major roles. These blood clotting factors are inactive proteolytic enzymes. When converted to the active forms their enzymatic acrion causes successive reaction of the clotring process, resulting in the formation of prothrombinase (factor Xa-complex), which converts prothrombin to thrombin. Thrombin activity is regulared by complex formation wirh antithrombin LII, the main physiological inhibitor of blood coagulation. The resulting thrombin-antithrombin III complex (TAT) reflects coagulation activarion. Free thrombin leads to the formation of fibrin, which has to be degraded by fibrinolysis.

For this purpose, the inacrive enzyme precursor plasminogen is converted into the active protease plasmin by plasminogen acrivarors. Two types of plasminogen acrivarors have been identified: the tissue type (r-PA) and the urokinase type (u-PA). The control of plasminogen acrivator may occur at the level of synthesis and release, but also through its interaction with specific plasminogen acrivator inhibitors (PAI). PAI-1, initially called endorhelial cell PA inhibitor, is the most important PA-inhibitor in plasma. $\mathrm{PAI}-2$, the placental type inhibitor, appears to have a major role in the control of 


\section{COAGULATION}

Intrinsic pathway (XII, XI, IX, VIII) and extrinsic pathway (VII)

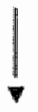

$\mathrm{Xa}+\mathrm{Va}+$ phospholipid+Ca: prothrombinase complex

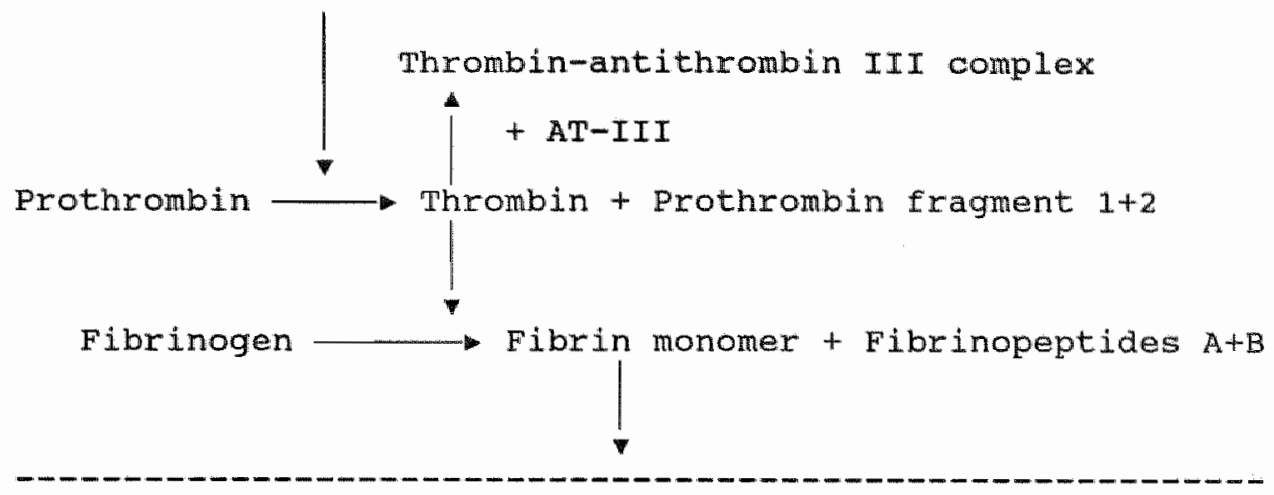

\section{FIBRINOLYSIS}

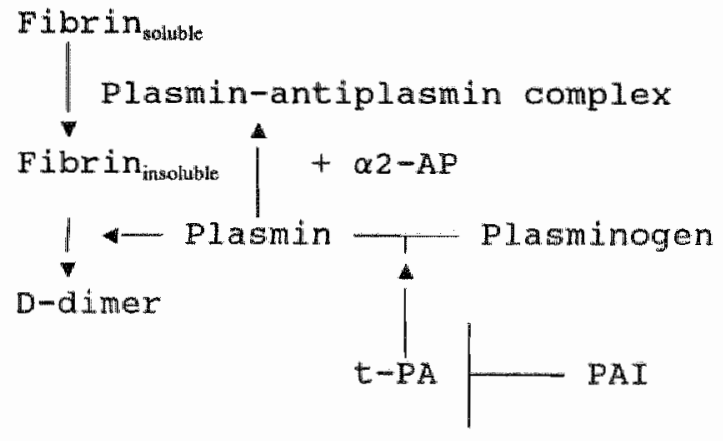

Fig 1. Coagulation and fibrinolysis

fibrinolys is in pregnancy, especially within the uteroplacental circulation. The plasminmediated degradation of cross-linked fibrin results in the formation of D-dimer fragments, which reflect activation of fibrinolysis.

Variables of haemostasis during pregnancy have been studied over the last two decades and they indicate that a normal pregnancy is accompanied by changes in the hacmostatic system. This is thought to be a physiological adaptation necessary to ensure the integrity 
of the expanding maternal and fetal circulation in the placenta and to control bleeding at the rime of placental separation. Coagulation factors are increased during pregnancy, particularly in the last trimester. This is most striking in the case of plasma fibrinogen concentravion ${ }^{1-4}$, but is also observed with factors VII and VIII ${ }^{5}$ and, to a moderare extent, with factors $\mathrm{X}, \mathrm{X}$ and XII. ${ }^{6}$ Facrors $I I$ and $\mathrm{V}$ remain unchanged whereas facrors $\mathrm{XI}$ and XIII even show a decrease. ${ }^{7-9}$ Antichrombin III (AT-III), an important inhibitor of thrombin, is unchanged in nomal pregnancy 10,11 , bur is decreased in preeclampsia. ${ }^{12}$

Fibrinolytic activity has been reported as being reduced during pregnancy, particularly in the last trimester. ${ }^{13-15}$ Stirling et a ${ }^{5}$ described a marked decrease in fibrinolyric activity from $11-15$ weeks of gestation. Most investigators have found that plasminogen levels increase during pregnancy ${ }^{13-15}$ at the same time as the fibrinogen levels. ${ }^{14}$ Levels of $\alpha_{2}$-antiplasmin are also reported to increase. ${ }^{15}$ Several lines of evidence suggest that smoking also affects the coagulation system as shown by higher plasma fibrinogen and TAT levels. ${ }^{16}$ Decreased production of tissue plasminogen activator ${ }^{17}$ and increased levels of plasminogen activator inhibitor ${ }^{18}$ indicate a reduction of fibrinolysis in smokers. These effects are more pronounced immediately after smoking. ${ }^{16}$

in order to investigate the simultaneous effects of smoking and pregnancy on haemostasis a number of tests for parameters of the coagulation and fibrinolytic systems were performed. To monitor coagularion activation, levels of F $1+2$, a sensitive marker for activation of coagularion ${ }^{19}$ and TAT III, a marker of inhibition of coagulation ${ }^{20}$, were measured. Plasminogen, $\alpha_{2}$-antiplasmin and D-dimer levels were determined in order to measure the fibrinolytic activity. In combination, these tests yield information about changes in the balance berween coagulation and fibrinolysis that may occur as a result of smoking during pregnancy. To our knowledge, studies in this field have not previously been reported.

\section{Subjects and methods}

The study was conducted in the de Wever Hospital, a reaching hospital serving a population of 200,000 inlabitants. Altogether, 101 pregnant women attending the deparment of obsterrics were included in the study. All participants gave their informed consent. The duration of the gestation was based on the last menstrual date and ultrasound determinations between 8 and 14 weeks. The number of cigaretres smoked per day was an estimare by the patient, in most cases confirmed by her partner. Non-smokers $(n=44)$ were defined as pregnant women reporting no smoking. All the smoking wonnen $(n=57)$ consumed 20 cigarettes a day or more. Cotinine, a nicotinespecific metabolite and one of the most accurate biochemical assessments of nicorine exposure 21 . was measured in the plasma of 20 (randomly selected) women to confirm their smoking habits. 'This was done in the second trimester of their pregnancy. 
Exclusion criteria were a diastolic pressure $\geq 90 \mathrm{mmHg}$ at the beginning or during pregnancy, an endocrine disease, a coagulation disorder or the use of medication known to interfere with the haemostatic system. Women with a history of (pre)eclampsia. hypertension, diabetes, a coagulation disorder, abruprio placentae, immature or premature delivery or a baby small for gestational age were excluded from the study. The characteristics of the women and their deliveries are summarized in Table 1 . For the evaluation they were ranked into four groups according rheirgestational age: 0 - 10 weeks, 11-20 weeks, 21-30 weeks and 31-40 weeks of gestation. Nor all parients were checked in all four stages.

Blood samples (al.ogether 201) were drawn between 8.30 and 9.00 a.m. after fasting overnight for ten hours followed by a resting period of 20 minutes. At least one hour had elapsed since the last cigarette. All parameters were determined in citrated plasma which was prepared by centrifugation of a mixture of 9 volumes freshly drawn blood with one volume trisodium citrate $\left(0.11\right.$ mol/l) for 30 minutes $(1600 \mathrm{~g})$ at $25^{\circ} \mathrm{C}$. The plasma was stored at $-70^{\circ} \mathrm{C}$ in plastic tubes and thawed with tap water of $37^{\circ} \mathrm{C}$ for 5 minutes before serial analysis.

Prothrombin fragment $1+2$ and thrombin-antithrombin III were assessed in plasma using an ELISA test of Behring Corporation (Marburg, Germany).

The D-dimer fibrin degradarion products were measured by means of the ELISA rest of Boehringer Mannheim, Germany. Tissue plasminogen acrivaror antigen was also analysed using an ELISA technique (Innogenetics, Antwerp, Belgium). The same

Table 1. Basic characteristics of the pregnant women

\begin{tabular}{|c|c|c|c|c|c|}
\hline Groups of parients & $\begin{array}{l}\text { Age }^{\text {al }} \\
\text { (years) }\end{array}$ & $\begin{array}{l}\text { Gestacion } \\
\text { (days) }\end{array}$ & $\begin{array}{l}\text { Birth weighta } \\
(\mathrm{g})\end{array}$ & $\begin{array}{l}\text { Placencal weighr } \\
\text { (g) }\end{array}$ & Blood loss : \\
\hline \multicolumn{6}{|l|}{ Nulliparous } \\
\hline Non-smokers $(n=20)$ & $\begin{array}{l}(28) \\
(25-32)\end{array}$ & $\begin{array}{l}40.1 \\
(39.0-41.1)\end{array}$ & $\begin{array}{l}3505 \\
(3050-3890 !\end{array}$ & $\begin{array}{l}490) \\
(40)-610)\end{array}$ & $\begin{array}{l}300 \\
(250-500)\end{array}$ \\
\hline Snokers $(n=17)$ & $\begin{array}{l}29 \\
(25 \times 34)\end{array}$ & $\begin{array}{l}39.0 \\
(38.0-40.4)\end{array}$ & $\begin{array}{l}2820 \\
2510-3310)\end{array}$ & $\begin{array}{l}460) \\
(400-540)\end{array}$ & $\begin{array}{l}300 \\
(200-400)\end{array}$ \\
\hline \multicolumn{6}{|l|}{ Parous } \\
\hline Non-smokers $(n=24)$ & $\begin{array}{l}28 \\
(25-32)\end{array}$ & $\begin{array}{l}40.1 \\
(39.0-41.1)\end{array}$ & $\begin{array}{l}3600 \\
(3178-3895)\end{array}$ & $\begin{array}{l}510 \\
(445-(355)\end{array}$ & $\begin{array}{l}300 \\
(200-400)\end{array}$ \\
\hline Smokers $(n=40)$ & $\begin{array}{l}29 \\
(25-34)\end{array}$ & $\begin{array}{l}39.0 \\
(38.0-40.4)\end{array}$ & $\begin{array}{l}3060 \\
(2665-3475)\end{array}$ & $\begin{array}{l}480) \\
(400-560)\end{array}$ & $\begin{array}{l}300 \\
(200-300)\end{array}$ \\
\hline
\end{tabular}

a Values represent median (IR). 
company supplicd the plasminogen and $\alpha_{2}$-antiplasmin reagents: Coatesi plasminogen and Coatest $0_{2}$-antiplasmin, both using the chromogenic substrate $\$-2251$.

The Mann-Whitney-Wilcoxon test was used for the statiscical comparison of the median values.

\section{Results}

Table 2 shows the median values of prothrombin fragment $1+2$ in the non-smokers and in the smokers. These fragments rose significantly in both groups from the beginning to the end of pregnancy; from $0.8 \mathrm{nmol} / 1$ to $2.5 \mathrm{nmol} / \mathrm{l}$ in the non-smokers group and from $1.0 \mathrm{nmol} / \mathrm{l}$ to $1.8 \mathrm{mmol} / \mathrm{l}$ in the smoking group. The smoking group showed significantly lower values in the second half of gestation $(1.4$ and $1.8 \mathrm{nmol} / \mathrm{l}$ versus 1.7 and $2.5 \mathrm{nmol} / \mathrm{l}$ in the non-smokers).

In the same Table the TAT concentrations in plasma of smoking and non-smoking pregnant women are compared. The concentrations nose significantly in both groups during pregnancy; from $2.2 \mu \mathrm{g} / /$ to $9.9 \mu \mathrm{g} / \mathrm{L}$ in the non-smokers and from $3.1 \mu \mathrm{g} / 1 \mathrm{to}$ $8.5 \mu \mathrm{g} / 1$ in the smoking group. The median values in the non-smokers only differed significanty in the first ten weeks of gestation $(2.2 \mu \mathrm{g} / 1$ versus $3.1 \mu \mathrm{g} / \mathrm{in}$ the smoking group; $p=0.016$ )

The fibrinolysis variables in the smokers and in the non-smokers are illustrated in Table 3. This Table shows the median plasminogen levels in smokers and non-smokers during the four stages of gestacion. There was a significant rise in plasminogen levels in the first half of pregnancy from $112 \%$ to $139 \%$ in the smoking group and from $103 \%$ to $140 \%$ in the non-smokers (resp. $p<0.0001$ and $p=0.001$ ), and a plateau was reached in the second half of gestation. "The median $\alpha_{2}$-antiplasmin levels are shown in the same table. These levels remained constant in both groups during pregnancy, but the smoking women started with significandy higher levels $(119 \%$ versus $105 \% ; p=0.009)$. This Table also illustrates a progressive and significant increase in D-dimer fragments from the beginning to the end of pregnancy in the non-smokers (from $278 \mu \mathrm{g} / \mathrm{ml}$ to 847 $\mu \mathrm{g} / \mathrm{ml}$ ). This was also the case in the smokers, but only in the last three stages (from 278 $\mu \mathrm{g} / \mathrm{ml}$ to $520 \mu \mathrm{g} / \mathrm{ml}$ ). D-dimer levels in the smoking group were significantly lower in the last three stages of gestation in comparison to the values in the non-smoking group (stage IV $520 \mu \mathrm{g} / \mathrm{ml}$ in the smokers versus $847 \mu \mathrm{g} / \mathrm{ml}$ in the non-smokers; $\mathrm{p}<0.0001$ ). Table 4 displays the median D-dimedTAT III ratio in the two groups. The smoking women had significanrly lower ratios at all four srages of pregnancy (stage 1: 59 versus 117: $p=0.006$ : stage IV: 53 versus $\left.101 ; p=5.5 \times 10^{-6}\right)$. 
Table 2. F $1+2$ and TAT III during pregnancy" comparison in plasma of smoking and non-smoking women ar various srages of gestation ${ }^{2}$

\begin{tabular}{|c|c|c|c|c|}
\hline & Gestational & eks & & \\
\hline & $\begin{array}{l}0-10 \\
N S(n=9) \\
S(n=19)\end{array}$ & $\begin{array}{l}11-20 \\
N S(n=17) \\
S(n=32)\end{array}$ & $\begin{array}{l}21-30 \\
N S(n=22) \\
S(n=34)\end{array}$ & $\begin{array}{l}31-40 \\
N S(n=33) \\
S(n=35)\end{array}$ \\
\hline & $\begin{array}{l}\text { Median } \\
\left(25-75^{\text {th }}\right. \\
\text { percentile) }\end{array}$ & $\begin{array}{l}\text { Median } \\
(25-75 \mathrm{dh} \\
\text { percentilo) }\end{array}$ & $\begin{array}{l}\text { Median } \\
(25-75 \mathrm{dh} \\
\text { percencile) }\end{array}$ & $\begin{array}{l}\text { Median } \\
\text { 25-754h } \\
\text { percentiles }\end{array}$ \\
\hline $\begin{array}{l}\text { F } 1+2 \text { (nmoll }) \\
\text { Non-smokers }\end{array}$ & $\begin{array}{l}0.8 \\
(0.6-0.9)\end{array}$ & $\begin{array}{l}1.4 \\
(1.2 .1 .7)\end{array}$ & $\begin{array}{l}1.7 \\
(1.4-1.9)\end{array}$ & $\begin{array}{l}2.5 \\
(1.9-3.0)\end{array}$ \\
\hline $\begin{array}{l}\mathrm{F} 1+2 \text { (nmoll) } \\
\text { Smokers }\end{array}$ & $\begin{array}{l}1.0 \\
(0.8-1.3)\end{array}$ & $\begin{array}{l}1.2 \\
(0.9-1.5)\end{array}$ & $\begin{array}{l}1.4 \\
(1.2-1.7)\end{array}$ & $\begin{array}{l}1.8 \\
(1.6-1.9)\end{array}$ \\
\hline $\begin{array}{l}\text { Significance S/NS } \\
\text { p-value }\end{array}$ & n.s. & n.s. & 0.03 & 0.00002 \\
\hline $\begin{array}{l}\mathrm{TAT}(\mathrm{Lg} /)) \\
\text { Non-smokers }\end{array}$ & $\begin{array}{l}2.2 \\
(1.8-2.8)\end{array}$ & $\begin{array}{l}4.7 \\
(3.9-6.0)\end{array}$ & $\begin{array}{l}7.4 \\
(6.6-9.5)\end{array}$ & $\begin{array}{l}9.9 \\
(7.5-12.0)\end{array}$ \\
\hline $\begin{array}{l}\text { TAT }(\mu g /) \\
\text { Smokers }\end{array}$ & $\begin{array}{l}3.1 \\
(2.8-5.7)\end{array}$ & $\begin{array}{l}4.9 \\
(4.1-6.6)\end{array}$ & $\begin{array}{l}6.9 \\
(5.4-8.6)\end{array}$ & $\begin{array}{l}8.5 \\
(7.1-11.9)\end{array}$ \\
\hline $\begin{array}{l}\text { Significance } 5 / \mathrm{NS} \\
\text { p-value }\end{array}$ & 0.016 & n.s. & $\mathrm{n}_{\mathrm{n}} \mathrm{s}$ & n.s. \\
\hline
\end{tabular}

Significance (p-value)

0-10 ws 11-20weds $\quad 1-20$ ws $21-30$ wedks 21-30 vs $31-40$ wecks

F $1+2$ (nmolll)

Non-smokers

II.s.

$n . .8$.

0.0007

F $1+2(\mathrm{mmol} / \mathrm{l})$

Smokers

ก...

0.027

0.001

$\operatorname{TAT}(\mu \mathrm{g} /)$

Non-smokers

$<0.001$

$<0.001$

0.019

TAT (

Smokers

0.042

0.003

0.003

Abbreviarions are defined in rext: $N S=$ non-smoking, $5=$ smoking, n= sample sizo, 
Table 3. Fibrinolyric varables; walues are shown as nedian (IR)

\begin{tabular}{|c|c|c|c|c|c|}
\hline & \multicolumn{5}{|c|}{ Gevtational age (wecks) } \\
\hline & $\begin{array}{l}0-10 \\
M S(n=9) \\
S(n=19)\end{array}$ & $\begin{array}{l}11-20 \\
\mathbb{N S}(n=17) \\
S(n=32)\end{array}$ & $\begin{array}{l}21-30 \\
N S(n=22) \\
S(n=34)\end{array}$ & & $\begin{array}{l}31-40 \\
\text { NS }(n=33) \\
S(n=35)\end{array}$ \\
\hline & $\begin{array}{l}\text { Median } \\
(25-75 \text { th perc) }\end{array}$ & $\begin{array}{l}\text { Median } \\
(25-75 \text { th pere. }\end{array}$ & $\begin{array}{l}\text { Median } \\
\text { (25-75th perc.) }\end{array}$ & & $\begin{array}{l}\text { Median } \\
\text { (25-75rla perc.) }\end{array}$ \\
\hline $\begin{array}{l}\text { Pasminogen }(\%) \\
\text { Non-smokers }\end{array}$ & $\frac{103}{(102-113)}$ & $\begin{array}{l}140 \\
(126-158)\end{array}$ & $\begin{array}{l}147 \\
(138-158)\end{array}$ & & $\begin{array}{l}145 \\
(132-156)\end{array}$ \\
\hline $\begin{array}{l}\text { Plasuinogen (o/) } \\
\text { Smoleces }\end{array}$ & $\begin{array}{l}112 \\
(10 / 4-121)\end{array}$ & $\begin{array}{l}139 \\
(126-148)\end{array}$ & $\begin{array}{l}151 \\
(136-158)\end{array}$ & & $\begin{array}{l}151 \\
(140-160)\end{array}$ \\
\hline Significance NS vs 9 & $n \cdot s$. & n.s. & n.s. & & $n . s$. \\
\hline $\begin{array}{l}\text { Q2-anciplasmin (\%) } \\
\text { Non-smokers }\end{array}$ & $\begin{array}{l}105 \\
(97-113)\end{array}$ & $\begin{array}{l}107 \\
(98-112)\end{array}$ & $\begin{array}{l}107 \\
(102-114)\end{array}$ & & $\begin{array}{l}102 \\
(95-112)\end{array}$ \\
\hline $\begin{array}{l}\text { Q-anniplasmin }(\%) \\
\text { Smokers }\end{array}$ & $\begin{array}{l}119 \\
(117-129)\end{array}$ & $\begin{array}{l}124 \\
(119-133)\end{array}$ & $\begin{array}{l}126 \\
(120-131)\end{array}$ & & $\begin{array}{l}122 \\
(115-128)\end{array}$ \\
\hline Significance $\mathrm{NS}$ ws $\mathrm{S}$ & 0.009 & $<0.0001$ & $<0.0001$ & & $<0.0001$ \\
\hline $\begin{array}{l}\text { D-dimer }(\mu \mathrm{g} / \mathrm{ml}) \\
\text { Non-smokers }\end{array}$ & $\begin{array}{l}278 \\
(210-504)\end{array}$ & $\begin{array}{l}400 \\
(303-567)\end{array}$ & $\begin{array}{l}651 \\
(420-847)\end{array}$ & & $\begin{array}{l}847 \\
(681-1396)\end{array}$ \\
\hline $\begin{array}{l}\text { D-dirner }(\mu g / \mathrm{ml}) \\
\text { Smokers }\end{array}$ & $\begin{array}{l}215 \\
(165-255)\end{array}$ & $\begin{array}{l}287 \\
(220-360)\end{array}$ & $\begin{array}{l}413 \\
(290-470)\end{array}$ & & $\begin{array}{l}520 \\
(400-620)\end{array}$ \\
\hline \multirow[t]{3}{*}{ Significance NS vos } & nas.s. & 0.006 & $<0.0001$ & & $<0,0001$ \\
\hline & \multicolumn{5}{|c|}{ Significance ( $p$ walue) } \\
\hline & \multicolumn{2}{|c|}{$0-10$ ws $11-20$ mocks } & -30 weeks & \multicolumn{2}{|c|}{$21-30$ ws $31-40$ weeks } \\
\hline $\begin{array}{l}\text { Plaminogen }(\%) \\
\text { Non-smokert }\end{array}$ & $<0.000 !$ & n.s. & \multicolumn{3}{|c|}{ ก... } \\
\hline $\begin{array}{l}\text { Plasminogen (") } \\
\text { Snokers }\end{array}$ & 0.001 & $\mathrm{~ms}$ & Plasminogen (") & \multicolumn{2}{|l|}{ n.s. } \\
\hline & $n . s$. & \multicolumn{3}{|c|}{$\alpha 2$-anciplasmin $(\%)$} & $\mathrm{n}, \mathrm{s}$ \\
\hline & ax.s.s. & n.s. & \multicolumn{2}{|r|}{ n.s. } & \\
\hline $\begin{array}{l}\text { D-dimer }(\mu \mathrm{g} / \mathrm{ml}) \\
\text { Non-smokers }\end{array}$ & 0.04 & 0.0001 & \multicolumn{3}{|c|}{0.003} \\
\hline \multicolumn{3}{|l|}{ D-diner $(\mu \mathrm{g} / \mathrm{ml})$} & & & \\
\hline
\end{tabular}

Abbreviations are defuned in text, NS= non-smoking, $S=$ smoking, $n=$ sample size. 
Table 4. Comparison of the D-dimer/TAT III rarios at different srages of gectarion in plasma of smuking and non-smoking pregnane women

\begin{tabular}{|c|c|c|c|c|}
\hline \multirow[b]{2}{*}{ Gestational age (weeks) } & \multicolumn{4}{|c|}{ Median D-Dimer/TAT III ratio (25-75 percentile) } \\
\hline & $0-10$ & $11-20$ & $21-30$ & 3140 \\
\hline Smokers & $\begin{array}{l}59) \\
(31-80)\end{array}$ & $\begin{array}{l}56^{27} \\
(35-71)\end{array}$ & $\begin{array}{l}57^{3} \\
(47-69)\end{array}$ & $\begin{array}{l}\left.53^{4}\right) \\
(42-71)\end{array}$ \\
\hline Non-smokers & $\begin{array}{l}117^{1)} \\
(74-158)\end{array}$ & $\begin{array}{l}\left.81^{2}\right) \\
(73-121)\end{array}$ & $\begin{array}{l}\left.84^{3}\right) \\
(55-124)\end{array}$ & $\begin{array}{l}\left.101^{4}\right) \\
(76-128)\end{array}$ \\
\hline
\end{tabular}

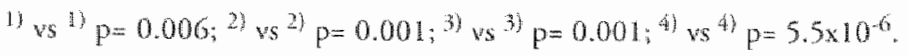

\section{Discussion}

Both pregnancy and smoking affect the haemostatic system and render a subject "hypercoagulable". Coagulation parameters were found to be increased in smokers as well as in pregnant women. 1-9, 17-19,22 Fibrinolytic activity has been reported to be diminished during pregnancy, parricularly in the last trimester: $13-15,22-24$

Studies of fibrinolysis in smokers have shown variable results. 'Two studies ${ }^{19,25}$ reported that fibrinogen levels were higher and that fibrinolysis was decreased in subjects who smoked. In two other studies, fibrinolytic activity measured as euglobulin clor lysis was reported to be enhanced after smoking 26,27 , whereas an orher group of investigators found no influence of smoking on fibrinolysis ${ }^{28}$. Kimura et al. ${ }^{29}$ studied the acute effect of cigarette smoking on haemostasis and found simultaneous increases in both coagulability and fibrinolysis during smoking.

It has been shown that an increase in the TAT concentration is a sensitive marker for acrivation of intravascular coagulation. $20,30,31$ The present sudy shows that in healthy non-smoking, pregnant women activation of the coagulation system takes place, as demonstrated by the significant increase of TAT from the beginning to the end of pregnancy. This is in keeping with results from Reinthaller and co-workers ${ }^{32}$ and an earlier study by our own group. 33 The TAT levels in the smoking group were nor significantly different from those in the non-smoking group and they also showed a significant increase during pregnancy. A lapanese group found that TAT levels in peripheral venous blood increased significantly immediately after smoking ${ }^{20}$ and remained elevated $41 \%$ above the baseline 15 minutes afterwards. These data suggest a transient activation of the coagulation system immediately after smoking. At this point one should be reminded that in the present study blood samples were not raken directly 
after cigaretre smoking but at least one hour later. It seems that habirual smoking does not have an addive emhancing ffect on the already activated coagularion in pregnancy. The fibrinolysis parameters showed a different patrern. In boch groups the plasminogen levels increased significanty in the first 20 weeks of pregnancy to reach a plateau in the second half of gestarion. Most investigators have found plasminogen levels to increase during pregnancy. ${ }^{33,34}$ Bonnar ${ }^{23}$ found that the increase in plasminogen levels occurred ar the same time as the increase in fibrinogen, the proportional rate of increase in the third trimester being in the ord of 50 to $60 \%$ with both fibrinogen and plasminogen. High plasminogen levels might be a protective measure against over-activation of clorring. Increased plasminogen levels could also be a reflection of diminished plasmin generation, indicacing a decrease of fibrinolytic activity. Several authors found the $\mathrm{Q}_{2}$-antiplasmin accivicy to be increased during pregnancy ${ }^{9,22}$ but in the present study the $\alpha_{2}$-anriplasmin levels appeared to be constant. The levels of fibrin degradation products (D-dimer fragments) were found to rise progressively and significandly from the beginning to the end of pregnancy. These results are in accordance with a study from Stirling et al ${ }^{5}$ and from our own group. ${ }^{33}$ Evidence that the process of intravascular coagulation in nomal pregnancy is confined to the placental area was produced by $V$ an Royen $^{9}$ and later by Bonnar et al ${ }^{35}$, who showed large: deviarions from normal hacmostasis in venous blood from the placental site than in blood from the forearm vein. The presence of raised FDP levels is therefore most likely to be the result of local (i.e. placental) degradarion of fibrin.

In the present study, the smoking women showed the same plasminogen levels as the non-smoking group whereas their $\alpha_{2}$-antiplasmin levels were significandy higher. The latter may imply a decrease in fibrinolyric acrivity, which is supported by the fact that D-dimer levels were significandy lower in the smoking group. The D-dimer/TAT ratio, which can be seen as an indicator of the balance berween fibrinolysis and coagulation, watreduced in the smoking group compared to the ratio in the non-smokers. There is a lack of balance bewween fibrinolysis and coagulation activation in the smokers in the sense that the scale tips towards coaguharion in them.

\section{Conclusion}

There is no indicarion of a reduction in fibrinolysis during normal pregnancy and the rise in D-dimer levels might even imply an increase. Habitual smoking does not have an additive enhancing effect on the already activated coagulation process in pregnancy. However, smoking during pregnancy leads to a reduction in fibrinolysis. In pregnant women who smoke the activated coagulation is not counterbalanced by an increase of fibrinolysis, as is the case in their non-smoking counterparts. This finding reflects an unfavourable effec of smoking duting pregnancy. 
Acknowledgements: The authors would like to express appreciation to Dr. B. Davies for revision of the manuscript and miss $\mathbb{P}$. Hawinkels for her involvement with this srudy.

\section{References}

1. Arocha Pinango CL, Linares ], Cova A. Martinez P. Is there a plywislogical incawascular congularion in obsternical cases? Acta Obstet Gynecol Scand 1979;58:27-30

2. Condie RG, Ogston D. Sequential sudies on components of the haemostaric mechanism in pregnancy with particular reference to the development of pre-edampsia. Br J Obster Gynacol 1976:83:93842

3. Flercher AP, Alkjaes $N K$, Bursein R. The infuence of pregnancy upon blood roagulation and plasma fibrinolycic enzyme funcrion. Am J Otwert Gynecol 1979:134743-51

4. Oliver RD, Patrerson BB. Puls JL. Thrombin dotable determination of plasma fibrinogen in pregnancy. Obster Gynecol 1976:47:299-303

5. Stirling $Y$, Wooll $L$, Nort WR, Segharchan MJ, Meade TW. Haemostasis in nommal pregnancy. Thromb Hacmost 1984:52:176-82

6. Beller FK, Ebert C. The coagulation and fibrinolytic enzyme system in pregnancy and in the puerperim. Eur J Obstet Gynecol Reprod Biol 1982:13:177-97

7. Gjonnaess H. Fagerhol MK. Sudies on coagulation and fibrinolywis in pregnancy, with special reference to cold acrivation of Facror VII. Acta Obster Gynecol Scand 1975,54:363-7

8. Nilsson IM, Kulllander S. Coagulation and fibrinolynic studies during pregnancy. Acra Obster Gynecol Scand 1967;46:273-85

9. Van Royen EA. Haemostasis in human pronancy and delivery. (disseration). Amsterdam: Universiry Mospiral Wilhelmina Gasduis, 1974

10. Weenink GH, Treffers PE, Kahlé LH, ren Cate JW. Antrithrombin III in normal pregnancy. Thromb $\operatorname{Res} 1982 ; 26: 281-7$

11. Weiner CP. Brande J. Plasma antidhrombin 111 acrivity in normal pregnancy. Obstel Gyncol $1980: 56: 601-3$

12. Kobayashi T. Terao T. Prechampsia as dmonic disseminated intravasular conguharon. Sudy of rwo

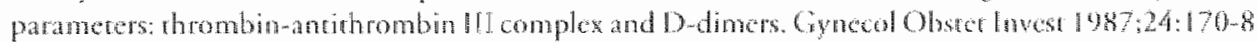

13. Biczinski J), HC Moore. Fibrinolysis in nomal pronancy. J Clin Pahol 1958:11:306-10

14. Cadroy $Y$, Boneu B. Gerinnung bei nomaler Schwangershafe und boi Cestuste. Diag lahor $1094: 44: 86-94$

15. Staper AG. Macintosh DM. Evans CM, Kyobe J. Fibrinolysis and plasminogen lewels in pregnancy and the puerperiom. Lancer 1965;2:706-8

16. Betch J]. Motede BM, Burns P, Lowe GD, Fortes CD. The affecs of acute moking on platelet behaviour, fibrinolysis and hacmorlyeology in habiewal snokers. Thomb Haemos 1984:51:6-8

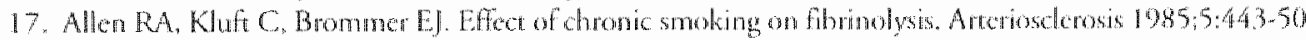

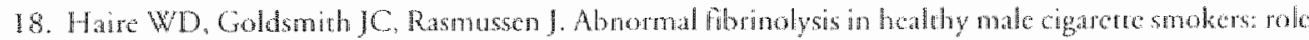
of plasminogen accivator inthibirors. An I/ Hematol $1989.31 .36-40$

19. Lau HK, Resenberg J5, Beeler DL, Rosenberg RD. The isolation and duaractiation of a specific antibody population directed aganse the prothrombin activation fragmonts $F 2$ and $F 1+2$. J Biol Chom $1979: 254: 8751-61$

20. Hock $I$ A. Sturk A, ten Cate JW, Lamping RJ, Berends F, Borm IJ. Laboratory and dinical evaluation of an assay of thrombin-antirhrombin 11 complexes in phama. Clin Chem $1988.34: 2058-62$ 
21. Partick DL, Cheadle A, Thompson DC, Dichr P, Kocpsell T. Kinne $S$. The validiry of self-repored smoking: a review and meta-analysis, An J Public Health 1994:84: 1086-93

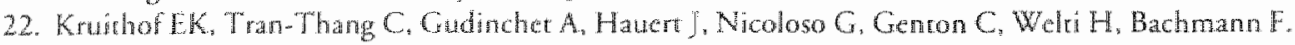
Fibrinolysis in pregnancy: a study of plasminogen acrivator inhibirors. Blood 1987;69:460-6

23. Bonar I. Daly L, Sheppard BL. Changes in the fibrinolytic systen during pregnancy. Semin Thromb Henose 1990;16:221-9

24. Mactarlane $R G$, Biggs $\mathbb{R}$. Observarions on fibrinolysis; spontaneous acriwiry associated with surgical operations, trauma, \& C. Lancet 1946;2:862-4

25. Mande TW, Chakrabart R, Hanes AP, Norh WR, Stirling Y. Characteristics affecring fibrinalytic activity and plasma fabrinogen concentrarions. Br Med J 1979:1:153-6

26. Aller RA, KJufr C. Brommer El. Acute effect of smoking on fibrinolysis: increase in whe activity level of cincularing extrinsic (rissue-type) plasminogen acrivator. Eur J Clin Invest 1984:14:354-61

27. Janzon L., Nisson IM. Smoking and Fibrinolysis. Circulation 1975:51:1120-3

28. Vicari AM, Margonato A, Macangni A, Luoni $\mathbb{R}$, Seveso MP. Vicedomini G et al. Effects of acure smoking on the hemostatic system in humans. Clin Cardial 1988;11:538-40

29. Kimural 5 , Nishinaga $M$, Ozawa T, Shimada $K$. Thrombin generation as an acure effect of cigaretre smoking. Am Heart J 1994:128:7-11

30. Blanke H, Practorus $G$, Leschke M, Scia R, Egbring R, Strater BE. Die Bedeutung des ThrombinAntithrombin IIl-Komplexes in der Diagnostik der Lungen-emboliz und der riefen Venenthrombose - Vergeich mir Fibrinopeprid A. Parrechen-faktor 4 und B-Thrombogko-bulin. Klin Wochenschr $1987: 65: 757-63$

31. Pelzer $H_{n}$ Schware A, Heimburger $N$. Determination of human thrombin-anti-thrombin III complex in plasma with an cnzyme-linked immunasorbent assay. Thromb Haenost 1988;59: 101-6

32. Reinthaller A, Mursch-Edmayr G. Tatra $G$. Thrombin-antithrombin III complex levels in normal pregnancy with hypentensive disorders and after dellivery. Br J Obster Gynateol 1990:97:506-10

33. Van Wersch JW. Ubachs JM. Blood coagulation and fibrinolysis during normal pregnancy. Eur J Clin Chem Clin Biochem 1991:29:45-50

34. Sheppard BL, Bonnar . The wltastructure of the arterial supply of the human placena in early and lare pregnancy. J Obstet Gynacol Br Commonw 1974:81:497-511

35. Bonmar J, Prentice CR, MCNicol GP. Douglas AS. Hacmostaric mechanism in the uterine circulation during placental separtion. Br Med J 1970:2564-7 
Chapter 9

\section{Haematological variables in cord blood of neonates of smoking and non-smoking mothers}

Patricia EAM Mercelina-Roumans', RBGE Breukers', JMH Ubachs' ${ }^{1}$,WW wan Wersch ${ }^{2}$

From the Department of Obstetrics and Gynaecologyl, and the Deparment of Haematology ${ }^{2}$, De Wever Hospital, Heerlen. The Netherlands. 


\section{Abstract}

Smaking during pregnancy is associated with maternal and fetal complications. In the present study the effect of maternal smoking on neonatal cellular blood components was imvestigated. The values of whole blood cell count, leucocyte differential count, thrombocyte and veticulocyte count were derermined and compared in cord blood of neonates of non-smoking $(n=89)$ and swoking $(n=53)$ mothers. The variables of the erythrocyte and thrombocyte count were not different in cord biod of neorates who were exposed to smoke and in thase who were not. In the resiculocyte range the reticulocyte count was significantly lower in the smoking group, while the reticulocyte subsets remained stable. The neutrophils were significantly lower in cord blood of neonates of smoking mothers $(p<0.05$ ). The latter finding might be an explanation for the enhanced incidence of posmatal infection seen in children of smoking mothers.

Smoking during pregnancy is associated with negative effecrs on the developing fetus such as increased frequency of pregnancy complications, reduced birth weight and increased perinatal mortality. ${ }^{1,2}$ Immediate effecrs are decreased intervillous blood flow ${ }^{3}$ and increased fetal heart rate. ${ }^{4}$ Nicotine and carbon monoxide are the two main constituents in cigarette smoke exerting harmful effects on the ferus. Nicotine has a constricting effect on uterine blood vessels and interferes with the blood supply to the ferus. It has a direct vasoconstrictive effecr on the ferus ${ }^{5}$ and produces capillary damage in the placenta ${ }^{6}$ Carbon monoxide binds to haemoglobin and produces a conformational change in carboxyhaemoglobin that results in a shift of the oxygen dissociation curve leading to diminished transmission of oxygen to the tissues at a given oxygen tension, causing a mild form of hypoxia?

Long term effects of smoking during pregnancy are also known. Children exposed to materral smoking in utero are said to have significantly more neuropsychological deficits than children who have nor been exposed. ${ }^{8-10}$ An American epidemiological study showed an increased risk of 1.6 for malformations in children of mothers who smoked more than 20 cigaretres a day during pregnancy. 11 The available evidence is inconclusive on cancer risks for children of morhers who smoke during pregnancy. Pershagen et al ${ }^{12}$ performed a cohort study, using information from the National Swedish Medical Birth and Cancer Registries. The maximum follow-up age was 5 years. They found no increase in owerall cancer risk in children of mothers who reported smoking during pregnancy. Two studies indicared a clear dose related increase in cancer risk, which was particularly marked for acure leukemias. ${ }^{13.14}$ The fetus can metabolize some of the genotoxic compounds found in tobacco smoke to DNA-binding metabolites. The presence of DNA adducrs in fetal tissue is indicarive of potential genomic damage that may result in an increased risk for the development of serious diseases, such as cancer in childhood or in later life. ${ }^{15}$ 
There is also a general agreement that exposure to envirommental tobacco smoke also has an adverse effect on the health of children, espectally on respirarory illnesses. 16 since the early 1970 s several scudies reported an associarion between the smoking habits of parents and the pulmonary morbidiry of their children. 16 . 18 Children with smoking parents have more respiratory infections, more respiratory problems such as asthma and, more hospital admissions for bronchitis and pneumonia. "19 has been observed that childhood exposure to parental (manly maternal) smoking is associated wirh the presence of asthma $20-24$ and increased nonspecific bronchial hyperresponsiveness. ${ }^{25}$ While studying the role of environmental robacco smoke in the devalopmenc of bronchial hyperresponsiveness in childen Agudo et al ${ }^{26}$ came to the conclusion that the only relevan source of environmental tobacco smoke exposure at home is rhe mother. The proximity between mother and child could explain this. A mean birth weighe deficit of $88 \mathrm{~g}$ was found in newborns of non-smoking mothers whose farhers smoked more than 20 cigarettes a day 27 Neonates born to mothers who smoke weigh about $200 \mathrm{~g}$ less than those born to non-smokers. 27 in conclusion. maternal smoking seems to be more important than paternal smoking in relation to the halth of their ofspring.

The effect of smoking on blood cells in adults and especially pregnant womon is not yer clear. Cigarette smoking is known to be associated with elevarions in the peripheral leucocyce count. ${ }^{28}$ Little has been reported on the effect of chronic cigarette smoking on the erythrocytic system. It may decrease vitamin $\mathrm{B}_{12} 29$ which could lead to an elewarion of the mean corpuscular volune (MCV). Heavy long term smoking may cause erythrocytosis. 30 "The haemoglobin synthesis might be impained by the lead content of tobacco. 31 Finally, smoking increases plasma viscosiry. ${ }^{32}$ An increase of platelec turnover and a decrease in placelet survival was found in smokers. ${ }^{33,34}$ Platelec counts either remained nomal 33,35 or were increased. 36,37

Even less is known about the effect of smoking during pregnancy on blood cells in neonates. Nicotine and cotinine cause a reduction in uteroplacental blood flow and lad to hypoxia of the ferus 38 which in cun has been reported to provoke stimulation of the retal erythropoiesis. ${ }^{39-42}$ This is thought to increase the total red blood cell count, the haemoglobin and the hacmatocrit. 39,43 Reticulocytes are reported to increase. $34,40,44$ Nevertheless, some authors clam that smoking has no relation to asphyxiat on to haemoglobin and haematocrit levels. 2,47 Neonatal blood platelets show linte or no increase $48-50$ or decrease. $39-51$

The mechanisms by which cigarette smoking produces adverse heal theffects are complex and multifactorial. The goal of the present sudy was ro invertigate wherher these offects are reflected or mediated by haematological changes in the neomate. As changes in the leucocyce, erythrocyre, reviculocyte and thrombocyce range might be expected, whe clinical relevance of haematological changes had to be assessed. 


\section{Subjects and methods}

The study was done in the De Wever Hospital, Heerlen. The Netherlands, a teaching hospital serving a population of about 200,000 . Hunded and ninery seven pregnant women, consecutively atcending the deparment of Obstetrics between November 1992 and April 1993 were asked to participare in the study. Only five women refused. The duration of the gestation was based on the last menstrual date and ultrasound determinations between 8 and 1.4 weeks. The number of cigarettes smoked per day was an estimation by the patient, in most cases confirmed by her partner. Cotinine, a nicotine specific metabolite, was assessed in the plasma of the mother ro confirm her smoking habits. This was done in the second trimester of their pregnancy. Cotinine is one of the most accurate biochemical assessments of nicotine exposure. 52 If a woman smoked more than four cigarettes a day she arbitrarily was categorized as a smoker. Non-smokers were defined as mothers reporting no smoking. There finally were 60 smokers and 110 women who did not smoke. Only 6 women smoked more than 15 cigarettes a day. This group was too small to subdivide the smokers into an intermediate smoking $(5-15$ cigarettes a day) and a heavy smoking group ( 15 cigarettes a day). Information on passiwe smoking (smoking partner) was not available.

Neonates whose mothers had a diastolic pressure $\geq 90 \mathrm{~mm} \mathrm{Hg}$, an endocrine disease or a coagulation disorder were excluded from the study, because these diseases might interfere with the haematological system. In the end the study group consisted of 142 singleton newborns, 64 males and 78 females, born from 89 non-smoking and 53 smoking mothers (Table 1). They were born at 34 weeks or more and with a birth weighr berween the $2.3 \mathrm{th}$ and 97.7 th. percentile for gestational age. Their Apgar score after 1 minute was 7 or more and the arterial umbilical cord $\mathrm{pH}$ was above 7.20 . All neonates were declared healthy after examination.

Verous cord blood samples were taken of the clamped umbilical cord immediately after delivery. These samples werc collected in EDTA-K 2 containing tubes (Sarstedt, Numbrecht, Germany). To avoid in vitro changes of the blood cells they were kept at room renperarure for a maximum of 3 hours before they were run on a $5 y$ smex $\mathrm{NE}-8000$ and a Sysmex R-3000 (Toa Medical Elecronics Corp., Kobe, Japan).

The Sysmex NE-8000 is an automated haematology analyzer that uses the rechnology of radiofrequency and direcr current measurement for cell counting and differentiacion. 53 Reticulocyte counting was done by How cytometry (Sysmex R-3000) which measures the absolute reticulocyte counc and gives a cytogram, from which the reticulocytes an be subdivided into low (LFR), medium (MFR) and high (HFR) Alworescence rario rericulocytes, in that order indicating the three stages in maturation of the reticulocytes. ${ }^{54}$ Both instruments made it possible to obtain some relatively new haematological parameters that have dinical relevance. The earlier described reticulocyte subsets allow a more accurate evaluation of the bone marrow activiry than does the total reviculocyte count. 55 The antomated reticulocyte counter was evaluated for use in 
Table 1 . Basic characteristics of 89 non-smoking and 53 smoking pregnant women

\begin{tabular}{|c|c|c|c|c|c|}
\hline Groups of patients & $\begin{array}{l}\text { Age } \\
(\text { years })^{a}\end{array}$ & $\begin{array}{l}\text { Gestacion } \\
(\text { days })^{\mathrm{a}}\end{array}$ & $\begin{array}{l}\text { Frequency } \\
(\%)\end{array}$ & $\begin{array}{l}\text { Birch weight } \\
(\mathrm{g})\end{array}$ & $\begin{array}{l}\text { Placental weight } \\
\text { (g) }\end{array}$ \\
\hline \multicolumn{6}{|l|}{ Nulliparous women } \\
\hline Non-smokers & $\begin{array}{l}29.5 \\
(27-32)\end{array}$ & $\begin{array}{l}281 \\
(275-287)\end{array}$ & 48.3 & $\begin{array}{l}3395 \\
(214)\end{array}$ & $\begin{array}{l}517 \\
(232)\end{array}$ \\
\hline Smokers & $\begin{array}{l}29.0 \\
(26-31)\end{array}$ & $\begin{array}{l}276 \\
(273-283)\end{array}$ & 44.4 & $\begin{array}{l}3116 \\
(346)\end{array}$ & $\begin{array}{l}487 \\
(123)\end{array}$ \\
\hline \multicolumn{6}{|l|}{ Parous women } \\
\hline Non-smokers & $\begin{array}{l}29.5 \\
(27-32)\end{array}$ & $\begin{array}{l}281 \\
(275-287)\end{array}$ & 51.7 & $\begin{array}{l}3605 \\
(316)\end{array}$ & $\begin{array}{l}521 \\
(138)\end{array}$ \\
\hline Smokers & $\begin{array}{l}29.0 \\
(26-31)\end{array}$ & $\begin{array}{l}276 \\
(273-283)\end{array}$ & 55.6 & $\begin{array}{l}3309 \\
(358)\end{array}$ & $\begin{array}{l}544 \\
(185)\end{array}$ \\
\hline
\end{tabular}

a Values represent median (IR); ${ }^{b}$ Values represent mean (SD).

paediatrics for investigating reticulocyte reference intervals as well as the cortesponding maturity indices (LFR, MFR and HFR). Reticulocyte intervals showed no age difference for the period of 1 week to 16 years of age. Maturity grading revealed three clata groups: the first 5 days of life, the first week to the end of the first month, and then up to 16 years of age. ${ }^{56}$ Plateler size paramerers, reflected by the mean platelet volume (MPV) and platelet distribution width (PDW), provide more information about platelet biology ${ }^{57-61}$ Platelers have been reported to deteriorate in funcrional ability with both decreasing size ${ }^{57}$ and increasing age ${ }^{58}$

The following list of constituents was determined:

1. In the erythrocyte range the total red blood cell count (RBC), hacmoglobin (HGB), haematocrir (HCT), mean corpuscular volume (MCV), mean corpuscular haemoglobin (MCH), mean corpuscular haemoglobin concentration (MCHC), red blood cell distribution width-standard deviation (RDW-SD), red blood cell distribution width-coefficient of variation (RDW-CV).

2. In the reticulocyte range the total rericulocyte count (RET), low fluorescence ratio (LFR), mean fluorescence ratio (MFR) and the high fluorescence ratio (HFR).

3. In the thrombocyte range the total platelet count (PLT), platelet distribution width (PDW), mean platelet volume (MPV), plateler large cell ratio (which equals the percentage of cells with a volume of more than 12 l) (P-LCR). 
4. In the leucocyte range the total white blood cell count (WBC), neutrophilic granulocytes (NEUT), eosinophilic granulocytes (EO), basophilic granulocytes (BASO), monocytes (MONO) and lymphocytes (LYMPH).

The Mann-Whitney-U test was used to test the significance of differences berween groups at the $p<0.05$ level. A non-parametric test was used because the distribution of the values was nor Gaussian.

Table 2. Comparison of the median and mean values of the erythrocyte variables in cond blood of newborns of non-smoking and smoking mothers ${ }^{\text {in }}$

\begin{tabular}{|c|c|c|c|c|c|}
\hline \multirow[t]{2}{*}{ Vaniable } & \multicolumn{2}{|c|}{$\begin{array}{l}\text { Newborns of noll-smokers } \\
(\mathrm{n}=89)\end{array}$} & \multicolumn{2}{|c|}{$\begin{array}{l}\text { Mewborns of smokers } \\
(n=53)\end{array}$} & \multirow{2}{*}{$\begin{array}{l}\text { Significance } \\
\text { p-value }\end{array}$} \\
\hline & $\begin{array}{l}\text { Median } \\
\text { Meas }\end{array}$ & $\begin{array}{l}(25-75 \mathrm{perc}) \\
{[X \pm 2 \mathrm{SD}]}\end{array}$ & $\begin{array}{l}\text { Median } \\
\text { Meran }\end{array}$ & $\begin{array}{l}(25-75 \mathrm{perc}) \\
{[\mathrm{X} \pm 25 \mathrm{D}]}\end{array}$ & \\
\hline $\operatorname{RBC}\left(10^{12} / 1\right)$ & $\begin{array}{l}6.40 \\
4,37\end{array}$ & $\begin{array}{l}(4.13-4.62) \\
{[3.60-5.20]}\end{array}$ & $\begin{array}{l}4.32 \\
4.32\end{array}$ & $\begin{array}{l}(4.15-4.68) \\
{[3.40-5.24]}\end{array}$ & n.s. \\
\hline HGB (mmoll) & $\begin{array}{l}10.0 \\
10.1\end{array}$ & $\begin{array}{l}(9.5-10.7) \\
{[8.1-11.9]}\end{array}$ & $\begin{array}{l}10.1 \\
10.1\end{array}$ & $\begin{array}{l}(9.6-10.6) \\
{[8.1-12.3]}\end{array}$ & n.s. \\
\hline HCT $(\%)$ & $\begin{array}{l}47.9 \\
48.1\end{array}$ & $\begin{array}{l}(45.2-50.9) \\
{[38.2-57.2]}\end{array}$ & $\begin{array}{l}48.2 \\
48.2\end{array}$ & $\begin{array}{l}(45.11-50.9) \\
{[37.8-58.6]}\end{array}$ & n..s. \\
\hline $\operatorname{MCV}(\mathrm{A})$ & $\begin{array}{l}109.8 \\
110.1\end{array}$ & $\begin{array}{l}(107.4-113.3) \\
{[99.5-119.9]}\end{array}$ & $\begin{array}{l}109.8 \\
109.9\end{array}$ & $\begin{array}{l}(107.0-112.3) \\
(98.5-121.1)\end{array}$ & n.s. \\
\hline MCH (fmol) & $\begin{array}{l}2.3 \\
2.3\end{array}$ & $\begin{array}{l}(2.2-2.4) \\
(2 .|-2.5|\end{array}$ & $\begin{array}{l}2.3 \\
23\end{array}$ & $\begin{array}{l}(2.2-2.4) \\
(2.0-3.1)\end{array}$ & m.s. \\
\hline MCHC (mmol/l) & $\begin{array}{l}21.0 \\
20.9\end{array}$ & $\begin{array}{l}(20.6-21.3) \\
|20.6-22.5|\end{array}$ & $\begin{array}{l}21.0 \\
21.1\end{array}$ & $\begin{array}{l}(20.7-21.5) \\
(19.8-22.4)\end{array}$ & n.s. \\
\hline ROW SD $(A)$ & $\begin{array}{l}67.7 \\
68.4\end{array}$ & $\begin{array}{l}(63.6-72.6) \\
\mid 51.6-83.6)\end{array}$ & $\begin{array}{l}66.6 \\
67.8\end{array}$ & $\begin{array}{l}(63,0-72.1) \\
{[47.9 .84 .7]}\end{array}$ & $\mathrm{n} . \mathrm{s}$ \\
\hline RDW-CV $(\%)$ & $\begin{array}{l}16.8 \\
17.1\end{array}$ & $\begin{array}{l}(16.1-17.7) \\
(16.2-19.3)\end{array}$ & $\begin{array}{l}16.5 \\
16.7\end{array}$ & $\begin{array}{l}(15.9-17.4) \\
(13.5-19.5]\end{array}$ & n.s. \\
\hline
\end{tabular}

"abloreviations are defined in text. 


\section{Results}

In Table 2 the values of the erythocyte variables in cord blood of newbons of smoking $(\mathrm{n}=53$ ) and non-smoking (n=89) mothers are shown. There were no significant differences between these two groups with regard to the erythrocyte range.

Table 3 shows that the median reticulocyte count was significandy lower in the newborns of smoking than of non-smoking mothers $\left(149 \times 109 / 1\right.$ versus $\left.170 \times 10^{9} / 1\right)$. The other reviculocyce variables were not different berween the wo groups.

Table 4 shows the median values of the thrombocyce range These values were not different between the two groups.

In the leucocyte range the neutrophilic granulocytes were significandy lower in cord blood of children of smoking mothers (Table 5). In cord blood of non-smoking mothers the median value was $7.37 \times 10 \% / 1$ compared to $6.01 \times 10 \%$ in cord blood of smoking morhers.

Table 3 . Comparison of the median and mean values of the tericulocyce wariables in cord blood of newborns of non-smoking and smoking mothers ${ }^{a}$

\begin{tabular}{|c|c|c|c|c|c|}
\hline & \multicolumn{2}{|c|}{$\begin{array}{l}\text { Newboms of non-smokets } \\
(n=89)\end{array}$} & \multicolumn{2}{|c|}{$\begin{array}{l}\text { Newborns of smokers } \\
(\mathrm{n}=53 \mathrm{3})\end{array}$} & \multirow{2}{*}{$\begin{array}{l}\text { Significance } \\
p \text {-value }\end{array}$} \\
\hline & $\begin{array}{l}\text { Median } \\
\text { Mean }\end{array}$ & $\begin{array}{l}(25-75 \text { perc }) \\
{[\mathrm{X} \pm 2.5 \mathrm{D}]}\end{array}$ & $\begin{array}{l}\text { Median } \\
\text { Mean }\end{array}$ & $\begin{array}{l}(25-75 \mathrm{perc}) \\
{[\mathrm{X} \pm 25 \mathrm{D}]}\end{array}$ & \\
\hline $\operatorname{RET}\left(10^{\circ} / 1\right)$ & $\begin{array}{l}170.0 \\
166.0\end{array}$ & $\begin{array}{l}(145.8-192.6) \\
(100.6-231.4]\end{array}$ & $\begin{array}{l}149.0 \\
153.8\end{array}$ & $\begin{array}{l}(133.5-174.3) \\
\mid 75.7-231.9]\end{array}$ & 0.023 \\
\hline LFR $(\%)$ & $\begin{array}{l}61.5 \\
61.7\end{array}$ & $\begin{array}{l}(59.5-63.4) \\
(54.5-68.8)\end{array}$ & $\begin{array}{l}61.2 \\
61.5\end{array}$ & $\begin{array}{l}(58.8-63.8) \\
\mid 52.1-70.9]\end{array}$ & 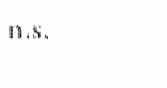 \\
\hline $\operatorname{MFR}(\%)$ & $\begin{array}{l}24.2 \\
24.5\end{array}$ & $\begin{array}{l}(22.7-26.6) \\
|18.4-30.5|\end{array}$ & $\begin{array}{l}25.6 \\
25.2\end{array}$ & $\begin{array}{l}(23.3-27.2) \\
|18.9-31.5|\end{array}$ & 17.s. \\
\hline $\operatorname{HFR}(\%)$ & $\begin{array}{l}1.4 .0 \\
13.9\end{array}$ & $\begin{array}{r}(12.5-15.4) \\
\{8.3-19.4\}\end{array}$ & $\begin{array}{l}13,1 \\
13.3\end{array}$ & $\begin{array}{l}(11.6-15.4) \\
(7.4-19.1]\end{array}$ & n.s. \\
\hline
\end{tabular}

abbreviations are delined in text. 
Table 4. Comparison of the median and mean values of the thrombocyte wariables in cord blood of newborns of non-smoking and snoking mothers

\begin{tabular}{|c|c|c|c|c|c|}
\hline & \multicolumn{2}{|c|}{$\begin{array}{l}\text { Newboras of non-smokers } \\
(n=89)\end{array}$} & \multicolumn{2}{|c|}{$\begin{array}{l}\text { Newboms of smokers } \\
(\mathrm{n}=53)\end{array}$} & \multirow{2}{*}{$\frac{\text { Significance }}{\text { p-value }}$} \\
\hline & $\begin{array}{l}\text { Median } \\
\text { Mean }\end{array}$ & $\begin{array}{l}(25-75 \mathrm{perc}) \\
{[\mathrm{X} \pm 2 \mathrm{SD})}\end{array}$ & $\begin{array}{l}\text { Mediar } \\
\text { Mean }\end{array}$ & $\begin{array}{l}(25-75 \mathrm{perc}) \\
{[\mathrm{X} \pm 2 \mathrm{DD}]}\end{array}$ & \\
\hline $\operatorname{PLI}\left(10^{9} \mathrm{~d}\right)$ & $\begin{array}{l}270 \\
269\end{array}$ & $\begin{array}{l}(237-32) \mid \\
\mid 98-440]\end{array}$ & $\begin{array}{l}277 \\
282\end{array}$ & $\begin{array}{l}(242-316] \\
{[131-433]}\end{array}$ & $\mathrm{m}_{3}, \mathrm{~s}_{\mathrm{H}}$ \\
\hline PDW $(\%)$ & $\begin{array}{l}11.9 \\
11.9\end{array}$ & $\begin{array}{l}(11.1-12.5) \\
(0.3-14.5)\end{array}$ & $\begin{array}{l}11.9 \\
11.8\end{array}$ & $\begin{array}{l}(11.1-12.9) \\
{[9.4-14.2]}\end{array}$ & $\mathrm{n}_{\mathrm{s}} \mathrm{s}$ \\
\hline $\operatorname{MPV}(\mathrm{A})$ & $\begin{array}{l}10.2 \\
10.2\end{array}$ & $\begin{array}{l}(9.7-10.6) \\
\llbracket 8.8-11.6 \rrbracket\end{array}$ & $\begin{array}{l}10.3 \\
10.3\end{array}$ & $\begin{array}{l}(10.1-10.9) \\
{[9.0-11.6]}\end{array}$ & 17.5. \\
\hline ए-LCR $(\%)$ & $\begin{array}{l}26.1 \\
26.1\end{array}$ & $\begin{array}{l}(22.8-29.2) \\
{[15.0-37.2)}\end{array}$ & $\begin{array}{l}26.7 \\
26.7\end{array}$ & $\begin{array}{l}(24.3-30.7) \\
{[16.5-36.9]}\end{array}$ & n.s. \\
\hline
\end{tabular}

abbrevations are defined in text.

Table 5. Comparison of the median and mean values of the leukocyte variables in cord blood of newborms of non-smoking and smoking morhers

\begin{tabular}{|c|c|c|c|c|c|}
\hline & \multicolumn{2}{|c|}{$\begin{array}{l}\text { Newborns of non-smokers } \\
(n=89)\end{array}$} & \multicolumn{2}{|c|}{$\begin{array}{l}\text { Newborns of smokers } \\
(n=53)\end{array}$} & \multirow{2}{*}{$\frac{\text { Significance }}{\text { puvalue }}$} \\
\hline & $\begin{array}{l}\text { Median } \\
\text { Menm }\end{array}$ & $\begin{array}{l}(25-75 \text { perc }) \\
|X \pm 2 S D|\end{array}$ & $\begin{array}{l}\text { Median } \\
\text { Mean }\end{array}$ & $\begin{array}{l}(25-75 \mathrm{perc}) \\
{[X+25 \mathrm{DD}]}\end{array}$ & \\
\hline WBC. $\left(10^{\circ} / 1\right)$ & $\begin{array}{l}13.3 \\
13.4\end{array}$ & $\begin{array}{l}(11.1-16.2) \\
\{5,2-21.5\}\end{array}$ & $\begin{array}{l}12.7 \\
13.0\end{array}$ & $\begin{array}{l}(9.8-15.3) \\
\mid 4.3-21.0\}\end{array}$ & n.s. \\
\hline NEUT & $\begin{array}{l}7.4 \\
7.4\end{array}$ & $\begin{array}{l}(5.4-8.8) \\
|1.7-13.1|\end{array}$ & $\begin{array}{l}6.0 \\
6.2\end{array}$ & $\begin{array}{l}(4.0-7.1) \\
{[1.0-11.1]}\end{array}$ & 0.028 \\
\hline LYMPH & $\begin{array}{l}3.8 \\
3.8\end{array}$ & $\begin{array}{l}(3.3-5.1) \\
|1.2-6.5|\end{array}$ & $\begin{array}{l}4.5 \\
4.4\end{array}$ & $\begin{array}{l}(3.0-5.1) \\
(1.2-7.7)\end{array}$ & n.s. \\
\hline MONO & $\begin{array}{l}1.6 \\
1.6\end{array}$ & $\begin{array}{l}(1.2-2.3) \\
|0-3.5|\end{array}$ & $\begin{array}{l}1.8 \\
2.0\end{array}$ & $\begin{array}{l}(1.0 .2 .4) \\
{[0-4.2]}\end{array}$ & n.s. \\
\hline $\mathrm{EO}$ & $\begin{array}{l}0.39 \\
0.4\end{array}$ & $\begin{array}{l}(0.23-0.54) \\
{[0.0 .8]}\end{array}$ & $\begin{array}{l}0.35 \\
0.4\end{array}$ & $\begin{array}{l}(0 .[9-0.54) \\
{[0-0.8]}\end{array}$ & $\mathrm{n} . \mathrm{s}_{\mathrm{m}}$ \\
\hline BASO & $\begin{array}{l}0.06 \\
0.06\end{array}$ & $\begin{array}{l}(0.04-0.09) \\
{[0-0.10]}\end{array}$ & $\begin{array}{l}0.06 \\
0.06\end{array}$ & $\begin{array}{l}(0.04-0.08) \\
{[0.02-0.10]}\end{array}$ & n.s. \\
\hline
\end{tabular}

abbrevations are defined in text. 


\section{Discussion}

The effect of smoking on blood cells in adults and neonates is not yet clear. In adults cigarette smoking is known to be associated with elevations in the peripheral leucocyte count $^{28}$ and erythrocyte count ${ }^{30}$ Platelet counts either remain normal ${ }^{33,35}$ or increase 36,37 Information on the effect of smoking during pregnancy on neonatal blood cells is controversial. ${ }^{38-51}$

Prior to investigating the effects of maternal smoking on neonatal blood components, the effect of smoking during pregnancy on maternal haematological variables was studied. ${ }^{62-65}$ Smoking in pregnancy appeared to have an additive enhancing effect on the already known leucocyce increase in pregnancy. The leucocyce differential count showed that the increase was mainly due to an increase of neutrophils, monocytes and lymphocytes. ${ }^{62}$ The thrombocyte count did not differ in smoking and non-smoking pregnant women. ${ }^{63}$ The erythrocyte count was significantly lower in smokers than in non-smokers. No statistically significant difference between the median haemoglobin and haematocrit levels was seen. The MCV was significantly higher in women who smoked, as was the MCH. The combination of the higher MCV and the lower erythrocyte count means less oxygen transport and might create a slight hypoxic condition for the fetus. ${ }^{64}$ The absolute reticulocyte count was lower in the smoking group throughout pregnancy, but this was significant only in the last 10 weeks of gestation. There was no difference berween the reticulocyte subsets of the smoking and the non-smoking group. Both groups behaved similarly during pregnancy: there was a decrease in the mature reticulocytes and an increase in the more immature reticulocytes, 65

The analyses of the blood cells in the cord blood displayed quite another picture. No significant difference between the values of the total leucocyte count, the erythrocyte count and rhrombocyte count was found in cord blood of the smoking and non-smoking group. In the leucocyte range only the neutrophilic granulocytes were significantly lower in cord blood of neonates of smoking mothers. The reticulocyte count was significantly lower in the smoking group, while the reticulocyre subsers, which allow a more accurate evaluation of the bone marrow activity than the total reticulocyte count ${ }^{55}$, showed no differences between the two groups. One should be aware however that in view of the numerous variables tested the statistical differences might have occurred by chance.

In normal feruses the lymphocyte count increases linearly with gestation. At 20 weeks the levels are about $50 \%$ of those at term. 66 These high numbers of lymphocytes are needed to acquire antigen recognition functions, necessary in case of wiral infections that can pass the placenta. Neutrophil counts are low until 32 weeks and increase thereafter to adult levels at term $\left(1.8-8 \times 10^{9} / 1\right) .66$

In flow cytometric studies mature neutrophils are reported only at term. ${ }^{67-69}$ This is supportive evidence for the hypothesis that the placenta forms an effective barrier for 
most bacteria and that consequenty a host-defense mechanism against bacterial infecvon is necessary only in the last trimescer in preparation for extrauterine life. 70

When a host acquires a bacterial infection, neutrophils are released from the neutrophil storage pool into the circulation and there is a compensatory increased proliferation of the mitotic neutrophils in the bone marrow. II Neonates have an increased suscepribility to infections, which has been attributed to immaturity of the phagocyte-macrophage system. 72.73 Neutrophils and monocytes play a crucial role in the host defense against pyogenic infecrions. ${ }^{7479}$ Harlap and Davies 17 found that the prevalence of hospital admission for infants with the diagnosis of bronchicis or pneumonia was twice as common in infants of smokers than in infants of non-smokers. Tager er al ${ }^{80}$, using pulmonary function studies, documented decreased lung growth during childhood and adolescence in association with parental smoking. The effect on respiratory morbidiry appears to be more, although not exclusively, selated to maternal rather than paternal smoking. Bassi et al ${ }^{81}$ developed a rat model of maternal smoking and demonstrated. that fetuses suffered from growth retardation with a predominant effect on lung growth. Deficient formation of pulmonary septa suggests that growth of the connective tissue may have been impared during pregnancy. It is not known whether the lung can recover from structural atterations due to antenatal maternal smoking. A study by Taylor and Wadsworth ${ }^{18}$ supports the concept that maternal smoking influences the incidence of respiratory illnesses in children mainly through a congenital effect and only to a lesser extent through passive exposure after birth. No differences in the rates of hospital admission were found in children whose mothers started smoking only afuer delivery as compared with children of mothers who had never smoked. Neonates born from smoking mothers have significandy lower neutrophil counts than children born from non-smokers. This finding is congruent with the increased risk for postnatal infection in children of smoking mothers.

In summary, neasurable effects of smoking on cord blood cell count were a reduction in the reticulocyte and the neutrophitic count. "Thus, from a hamatological point of wew the effec of smoking on the whole blood cell count of neonates is limited.

\section{References}

1. Kicinman JC. Piere MB J. Madans JH. Land GH. Schramm WF. The effects of maremal smoking an Feral and infan morality. Am J Epidemiol 1988:127:274-82

2. Wantighe RL. Change in observed birth weight assuciated with change in maternal cigarene smolking. An I Epridemiol 1983:117:668-75

3. Lehowita P. Fors M. The acure effec of smoking on intervillous blood flow of the placenta. Bry Otyser Giynaceol 1978:85:729-31

4. Quiglcy ME, Shechan KL. Wilkes MM. Yen SS. Effecs of marenal smoking on circulating catcholaminc lowds and feral hear rates. Am I Obstet Gynecol 1979;133:685-90

5. Ross EM, Butler NR, Goldstein H. Smoking hazards to the ferus. Br Med J 1973; $4: 51$ 
6. Mosier HD. Armstrong MK. Effecs of matemal intake of nicome on feral and newborn rats. Proc Soc Exp Biol Med, New York, 1964;116956-9

7. Moberg A. Sande H. Foss OP, Srewwig IT. Smoking during pregnancy - effects on the ferus and on whocyarate levels in mother and baby. Acta Paediat Scand 1979,68547-52.

8. Sexron M, For NL, Hebel JR. Prenatal exposure to tobaco: 11. Effecis on cognerive functioning ar age three. Int J Epidemiol 1990;19:72-7

9. Fergusson DM. Horwood L, Lynskey MT. Maremal smoking belore and after pregnancy: effecs on behavioral outcomes in middle childhood. Pediatrics 1993,92:815-22

10. Olds DL. Henderson CR Jr. Tarelbaum R. Inellecual impaiment in children of women who smoke cigareres during pregnancy. Pedianrics 1994:93:221-7

11. Kelsey IL, Dwyer T, Holford TR, Bracken MB. Maternal smoking and congeniral malformatons an epidemiological study. J Epidemiol Community Health 1978: 32:102-7

12. Pershagen G, Ericson A. Oterblad-Olausson P. Maternal smoking in pregnancy does is increase whe risk of child hood cancer? Ine J Epidemiol 1992;21:1:5.

13. Stjernfeldr M, Berglund K. Lindsren J. Ludwiagsson J. Matemal smoking during pregnancy and risk of childhood cancer. Lancet 1986;1:1350-2

14. John EM, Savitz DA, Sandler DP. Prenaral exposure to parenes' smoking and dildhood cancer. Am J Epidemiol 1991;133:123-32

15. ARC Monographs on the evaluation of the carcinogenic risk of chemicals to burnata, wol 38: Tobacco smoking. Lyon:IARC, $\$ 986$

16. Ranrakallio P. Relacionship of marernal smoking to morbidicy and mortaly of the child tip to the age of five. Aca Paediar Scand 1978:67:621-31

17. Harlap S, Davies AM. Infant admissions to hospital and maternal smoking Lance $1974,1529-32$

18. Taylor B, Wadsworth ]. Maternal smoking in pregnancy and lower respirarony tract illness in endly life. Arch Dis Child 1987,62:786-91

19. Eriksen MP. LeMaistre CA, Newell GR. Health hazards of passive smoking. Annu Rex Public Heath $1988 ; 9: 47-70$

20. Gortmaker SL, Walker DK, Jacobs FH, Ruch Ross H. Parental smoking and the risk of childhood asthma. Am I Public Health 1982;72:574-9

21. Burchfiel CM. Higgins MW, Keller JB. Howate WF, Burrer WJ, Higgins IT. Passive snoking in childhood. Respiratory condirions and pulmonary funcrion in Tecumseh, Michigan. Am Rev Respir" Disi $1986: 133: 966 \% 73$

22. Murray AB, Morrison B]. Passive smoking and the seasonat difference of scverivy of asth ma inchildron. Chese 1988,94:701-8

23. Andrae S. Axelson O. Bjorksten B. Fredritkson M, Kjolman N L Sympoms of bronchial hypercactrity and asthma in relation wo environmentallactors. Arch Dis Chid $1988 ; 63: 473-8$

24. Tage IB. Passive smoking - bronchial responsivenese and atopy (revicwo. Am Rew Respir Dis $1988 ; 138: 507.9$

25. "Tager 1B. "Passive smoking" and respiratory bealth in children - sophistry of caunc for concern? Am Rev Respir Dis 1986;33:950-61

26. Agudo A, Bardagf S, Romero PV. Gonzalc CA. Exerciscindeced anways narrowing and exposure io environmental cobacco smoke in schoolchildren. Am I Epidemiol 1994:140:409-17

27. Feath benefirs of Smoking Cessation a repont of the Sugcon General. Washington DC. Public Healm Service, Centers for Disease Control. Center for Chronic Disease Prevenrion and Heale Pronorion, Office on Smoking and Healeh:1990. US Depe of Healeh and Human Scrvices publication CDC $90-8416$

28. Schwart 1. Weiss ST. Host and enviromental facrors influcncing the peripheral blood leukocyte: count. Am J Epideniol 1991:134:1402-5) 
29. Jones $P D$. Hudson $N$, Hawkey CJ. Depression of saliwary epidermal growth facror by smoking. BMJ $1092 ; 304: 480-1$

30. Smich JR, Landaw SA. Smokers polycychemia. N Engl J Med 1978;298:6-10

31. Boydt JD. Butterworth CE Jr. Lead poisoning and hemoglobin synthesis. Am J Med 1962;32.884

32. Nowcomb PA, Carbone PP. Cigarerte smoking a dinical guide to assessment and reatment. Ch 2 . The heath consequences of moking: cancet. Medical Clinics of North America 1992;76 (2):340-1

33. Musard JF, Murphy EA. Effecr of smoking on blood coagulation and platelet survival in man. BMI $1963: 1: 846-9$

34. Fuster V, Chesebro IH, Frye RL, Elveback LR. Platelet surviwal and the development of coronary artery disease in the young adult: ffects of cigarerte smoking, srong farnily history and medical therapy. Circulation 1981;63:546-51

35. Ring T, Kustensen SD, Jensen PN, Mourits-Andersen T, Madsen H, Dyerberg J. Cigaretre smoking shorens the bleding time. Thromb Res 1983;32:531-6

36. Murchison LE, Fyfe T. Effects of cigarente smoking on serum-lipids, blood-glucose, and plarelex adhesiveness. Lance 1966;2:182-4

37. Eriksten J. Hellem A, Stemorken H. Chronic effect of smoking on plateler coun and "plateler adhesiveness" in presumably healthy middle aged men. Thromb Haemost 1977: 38:606-11

38. Pijpers L, Wadimiron JW, MeGhie JS, Bom N. Acute effect of matemal snoking on the maternal and fetal candiovascular system. Early Hum Dev 1984;10:95-105

39. Meberg A. Haga P. Sande H, Foss OP. Smaking during pregnancy: hemarological obserwations in the newborn. Acta Paediatr Scand 1979,68:731-4

40. Kundsen A. Maternat smoking and the bilimbin concentracion in the firs three days of life. Eur J Obstet Gynecol Reprod Biol 1991;40:123-7

41. Enst E, Marai A, Schmolal C. Magyarosy I. Dose-effect relarionship between smoking and blood weology, Be J Hacmatol $1987 ; 65: 485-7$

42. Gam SM, Shaw HA, McCabe KD. Effec of maternal smoking on hemoglobins and hematocrits of rhe newborn. Am ] Clin Nutr 1978,31:557-8

43. Linderkamp O, Stader AA, Zilow EP. Blood viscosiry and optimal hematocrit in preterm and full-term neonates in 50- to 500 micromerer tubes. Pedlatr Res 1992;32:97-102

44. Hsich C, Clarke G, Adey D, Cauchi MN. Smoking in pregnancy: relevance of maternal screening tess on Reral outcome. Eur J Obster Gynecol Reprod Biol 1984: 6:403-10

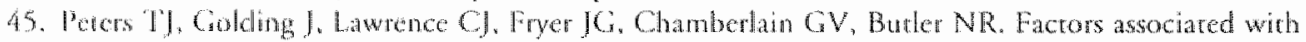
dedayed onset of regular respirarion. Farly Hum Dev 1984;9:209-23

46. Natcye RL. Feroces of maternal cigaretre smoking on the fetus and placenta. Br J Obsect Gynaecol $1978: 85: 732 \cdots$

4\%. Kontnorus JA, Detgrado LR, Knipsehild PG, Essed GG, Smits F. Haematologic parameters and pregnancy outcome. A prospective cohort study in the third wimester. J Clin Epideniol 1990,43:461-6

48. Tell CS. Crmm RH Jr. VellarOD, Theodorsen L. The relarionship of whe cell count, plarelet count, and hematocric to cigarete smoking in adolescents: the Oslo Yourh Study. Circulation 1985;72:971-44

49. Anthony HM. Reacrive changes in the blood of smokers and the development of arterial diseases and COPD, at revicw: cridence of associations between changes and subsequent disease with implications for the craluacion of harmful eftects of cigaretes, and for susceptibility wo the chronic effects of inhaled prillutants. Rev Environ Halth $1989,8: 25-86$

50. Eisen ME. Hammond EC. The effect of smoking on packed cell volume, red cell counts, haemoglobin and platelet counts Can Med Assoc \1956;75:520-3

51. Meberg A. Halvorsen \$. Transirory thrombogropenia in small-for-dare infants, and in newborn nice exposed to hypohatic hypoxia, cigarette smoke and $\mathrm{CO}$ gas inhalation during pregnancy. Proc Europ Suc Pacdiar Res Annual Meeting Turku 1978:58 
52. Parrick DL, Cheadle A, Thompson DC, Diehr P. Koepsell T. Kinne S. The validing of selfutported

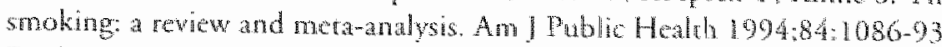

53. Bardy AH, Seppälä T, Lillsunde P. Koskela P. Gre CG. Objecrively rveasured wobaco exposure among pregnanc women in Finland in 1986 and 1990. Acra Obsret Gynecol Scand 1994:33:30-4

54. Schoenug RA. Hematology analyzers. Clin Lab Med 1988:8:653-73.

55. Yamada H. Clinical significance of reviculocyte coureng. Sysmex 1no $11990 ; 13: 121.7$

56. Herner KR, Böck A, Mühl A, Newhauer $\$$. Herner C. Rericulocye counting and manury grading in pediatrics using the Sysmex R-1000 aucomated reticulocye analyzer. Sysmex In \1992:2:4-9

57. Karpathin S. Heterogeneiry of human platevets. II. Funcrionat evidence suggestive of young and old platelecs. J Clin Invesi 1064:48:1083

58. Hirsh J. Glynn MF, Mustard JF. The effect of platelet age on platelet adherence to collagen. I Olin Invese $1968: 47: 466-73$

59. Thompson CB, Earon KA, Princiona SM, Rushin CA, Vateri CR. Sixe dependen platelet subpopularons: relarionship of plateler volume to ulerastucrure, enrymatic acrivity, and funcrion. Bt J Hacmatol $1982: 50.509-19$

60. Thompson CB, Jakubowski JA, Quin PG, Degkin D, Valcri CR. Marcle size and age detomine plateler funcrion independenty. Blood 1984;63:1372-5

61. Martin IF, Bath PM. Burr ML. Influence of platelet size on outcome after myocardat infarcion. Lancer $1991: 338: 1409-11$

62. Mercelina-Roumans PE, Ubachs JM, van Wersch JW. Leucocyce count and leucocye differential in smoking and non-smoking females during pregnancy. Eur J Obstet Gynecol Reprod Biol 1994:55:169-73

63. Merclina-Roumans PE, Ubachs IM, van Wersch JW. Plarelec coun and platele indices ar watious stages of nomal pregnaxy in smoking and non-smoking wonen. Eur J Clin Chom Clin Biochem $1095 ; 33: 267.9$

64. Mercelina-Roumans PE, Ubachs JM, wan Wersel JW. Erythrocyte count and indices during normal pregnancy of non-smoking and smoking women. Eur J Obseer Gynecol Reprod Biol 199457:25-8

65. Mercelina-Roumans PE. Ubachs JM, wan Wersol JW. The reticulocycoun and irs subfoctons in smoking and non-smoking pregnant women. Eur J Clin Chem Clin Biochem 1995:33:263-5

66. Davies ND, Buggins AG, Snijclers RJ, Jenkins E, Layton DM, Nicolaides KH. Blond lencocyce coun in the human ferus. Arch Dis Child 1992:67:399-3

67. Carr R. Pumford D. Davies IM. Ncutrophil chemotaxis and adhesion in pretem babics. Arch Dis Child $1092 ; 67: 813-7$

68. Torok C. Lundahl, Hed I. Lagercranc H. Diwessiy in regulation of adhesion molecules (MAC-1 and L-selectin in monocyes and neutophils from noonates and adults. Arch Dis Child 1993,68:561-5

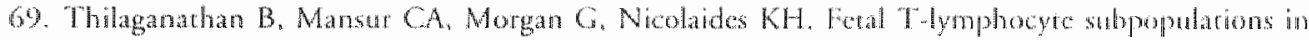
nomal pegrancies. Feal Diagn Ther 1992,753-64

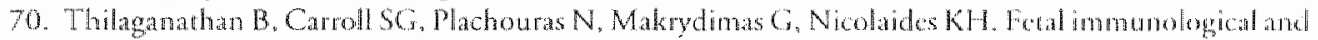

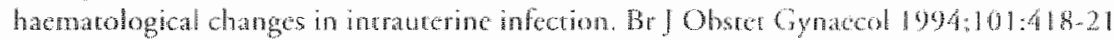

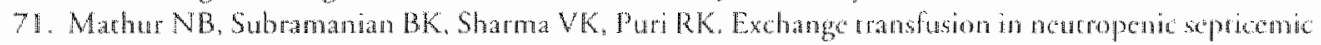
neonates: ffect on granuloge fumcrions. Acra Padiatr $1993,82: 939-43$

72. Christensen RD, Rothstein $G$. Exhaustois of mature marrow neutophils in neonate with scpsis.) Pediar 1980;96:316-8

73. Xanthou M. Leucocyc blood picure in ill newhom babis. Arch Dis Child 1972,67:741-6

74. Anderson DC, Hughes BJ. Smith CW. Abnormal mobility of neonatal polymorphounclear leukocyes. Relationship to impared rediscribution of surface athesion sites by chemotacic factor or colchine. J Clin Invest $1981: 68: 863-74$

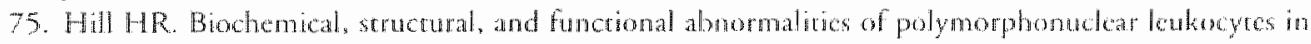
the newnece. Pediare Res $1987 ; 22: 375-82$ 
76. Arnaour Mit. Serucure and funcrion of the leukocye adhesion moleciles CD11/CD18. Blood $199075: 1037-50$

77. Anderson DC, Miller L, Schmalstieg FC, Rorhlen R, Springer TA Contriburions of the MAC-1 glycoprotein family to adherence-dependera granulocyte functions: structure-funcrion assessmencs employing suburit-spectic nonoclonal antibodies. Blood 1986;137:15-27

78. Jutia MA. Rorr L, Berg EL, Burcher EC. Funerion and regulation of the neutrophil MEL-14 antigen in wivo: comparison with LFA-1 and MAC-1.J Immunol 1989; \433318-24

79. Springer TA. Adhesion receptors of the immune system. Nature 1990:346:425-34

80. Tager 1B, Weiss ST, Munoz A, Rosner B. Speixer FE. Longirudinal study of the effects of maternal smoking on pulmonary function in chidden. N Engl J Med 1983;309:699-703

81. Bassi JA. Rosso P. Moessinger AC. Blanc WA, James LS. Fetal growth retardarion due to matemal robacco smoke exposure in the rat. Pediatr Res 1984;18:127-30. 


\section{Chapter 10}

\section{Cord blood cells and indices: smoking-related differences between the sexes}

Patricia EAM Mercelina-Roumans", RBGE Breukers' JMH Ubachs', JW' wan Werseb'

From the Deparment of Obsterrics and Gynaecology ${ }^{1}$, and the Deparment of Haematology ${ }^{2}$, De Wever Hospital, Heerlen. The Netherlands. 


\section{Abstract}

The values of whole blood cell count, leucocyte differential platelet and reticulocyte counts were determined in cord blood of both male $(n=64)$ and female $(n=75)$ newborns of 87 non-smoking and 52 smoking mothers.

Letucocytes and neutrophils in cord blood from male newbovns of smokers asere significantly Lower than those in their fenale counterparts and in the male newborns of non-smokers. These result suggest that male nuwborns are more affected by cigarente exposure than females with regard to some hacmatological paramicters.

The effect of smoking during pregnancy on blood cells in neonates is not clear. Nicotine and corinine cause a reduction in uteroplacental blood flow and lead to hypoxia of the fetus ${ }^{1}$ which in turn provokes stimulation of fetal erythropoiesis. ${ }^{2-5}$ In general, this is rhought to increase the rotal red blood cell count, the haemoglobin and the haemarocrit. $^{2,6}$ In addition, reticulocytes are reported to increase. ${ }^{2,3,7}$ Nevertheless, some authors clain that smoking has no relation ro asphyxia ${ }^{8}$ or to haemoglobin or haematocrir levels. 9,10 The effect of smoking on neonatal blood platelers is also in dispute. Some authors describe litte or no increase ${ }^{11-13}$, but others suggest thrombocytopenia. 2,14 Since the late 1970s, the dangers associated with passive (involuntary) smoking have been widely debared. While research throughout the world thas produced findings showing sidestream smoke to be harmful to non-smokers, an equal number of studies have indicated that the harm has been overstated or that it is non-existent. ${ }^{15}$ There are as yet no data on the influence of passive smoking on blood cells in neonares.

In animal studies, nicotine has been shown to have sex-dependent effects. ${ }^{16-18}$ prenatal nicotine treatment reduced both the number of male pups and male birth weight but female pups rended to be unaffected. In human adults, males are also the more affected gender. ${ }^{11.19}$ The aim of this study was to compare the erythrocyte, thrombogte, leucocyre and reticulocyre counts in cord blood from female and male newborns of smoking and non-smoking mothers, in order to clarify the potential gender differences in hacmatological variables.

\section{Subjects and methods}

The erythrocyte, reticulocyte, thrombocyte, leucocyte and leucocyte differential counts were deternined in venous umbilical cord blood from 139 singleton newborns $(64 \mathrm{M}$, 75 F) bom between November 1992 and April 1993 in the De Wever Hospiral Heerlen, The Nerherlands. All infants bom at term (37-42 weeks' gestation) were included, irrespective of their birch weight. Their births were normal with Apgar scores of 7 or more after 1 min and arterial umbilical cord $\mathrm{pH}$ above 7.20. All neonates were dedared healthy after examination. Their morhers were healthy pregnane women. Mothers with 
a diascolic pressure $\geq 90 \mathrm{mmHg}$, an endocrine disease or a coagularion disorder were excluded from the sudy. The duration of gestacion was based on the last menstrual date and ulrasound determinations between 8 and 14 weeks. The number of cigaretres smoked a day was estimated by the parient, and in most cases was confimed by the parner. If a woman smoked more than 4 cigarertes a day she was defined as a smoker. Only six women smoked more than 15 cigarettes a day. This group was too small to subdivide the smokers into intermediate smoking (5-15 cigarettes a day) and heavy smoking groups (> 15 cigareres a day). Non-smokers were defined as mothers reporting no smoking. Information on passive smoking (smoking partner) was not available.

Venous cord blood samples were obtained from the clamped umbilical cord immediarely afrer delivery. These samples were collected in EDTA-K 2 containing tubes (Sarstedt, Nümbrecht, Germany) and kept at room temperature for a maximum of 3 h before being run on a Sysmex NE-8000 and a Sysmex R-3000 reticulocyce counce (Toa Medical Electronics Corp., Kobe, Japan). The latter instrument gives the reviculocyte count as a percentage of the erythrocytes, the absolute rericulocyte counc, and a cytogram from which the reticulocytes can be subdivided inco low (LFR), medium (MFR) and high (HFR) fluorescence ratio reticulocytes, in that order, indicating the three stages in the maruration of the reticulocyte. Another automated reticulocyte counter, the Sysmex $\mathrm{R}-1000$ was evaluated for use in paediatrics for investigaring reticulocyte reference intervals as well as the corresponding maturity indices (LFR, MFR, HFR). Rericulocyte reference intervals showed no age difference for the period 1 week to 16 years of age. Maturity grading revealed three data groups: the first fwe days of life, the first week to the end of the first month and then up to 16 years of age. ${ }^{20}$

The following list of constituents was determined: in the erythrocyte range, total red blood cell count (RBC), haemoglobin (HGB), haematocrit (HCT), mean corpuscular volume (MCV), mean corpuscular haemoglobin (MCH), mean corpuscular haemoglobin concentration (MCHC), red blood cell distribution width-standard deviarion (RDW-SD), red blood cell distribution width-coefficient of wariation (RDW-CV). In the reviculocyte range, the cotal reticulocyte count (RED) was deremined, together wich the proportions of $L F R$. MFR and HFR reviculocy res. In the thrombocyte range, total plateler count (PLT) was carried our, together with the plateler distribution width (PDW), mean platelet volume (MPV) and plateler large cell ratio (= percentige of cells with a volume more than 12 A) (P-LCR). Counts of whire cells (WBC), ncurrophilic granulocytes (NEUT), cosinophilic granulocytes (EO), basophilic granulocytes (BASO), monocyres (MONO) and lymphocyes (LYMPH) wicte also performed. The Mann-Whimey-U rest was used to rest the significance of differences berween groups at the $p<0.05$ level. 


\section{Results}

In Table I the values of the erythrocyte, reticulocyte and leucocyte variables in cord blood of female newborns of smoking $(n=29)$ and non-smoking ( $n=46)$ mothers are presented rogether with the results of male newborns of smoking ( $n=23$ ) and non-smoking ( $n=41)$ mothers. Only significantly different values are shown. Of the erythrocyte variables, only RDW-CV was significanty lower in the total group of female newborns. The red cell count was $4.41 \times 10^{12} / 1$ in the male group compared with $4.34 \times 10^{12} / 1 \mathrm{in}$ the females. HGB was $10.1 \mathrm{mmol} / \mathrm{l}$ in the male group and $10.0 \mathrm{mmol} / \mathrm{in}$ females. The reticulocyte count showed no significant differences in the two groups $\left(151.5 \times 10^{9} / 1\right.$ in the male group, $170.1 \times 10^{9} / 1$ in the females). The HFR reticulocytes were significanty fewer in the female group. Platelet count and platelet indices were similar in both groups: PLT $270 \times 10^{9} / 1$ in the males and $278 \times 10^{\%} / 1$ in the females, PDW $11.9 \%$ in both groups, MPV $10.3 \mathrm{fl}$ compared with $1.0 .2 \mathrm{fl}$, P-LCR $26.6 \%$ versus $25.7 \%$. The leucocyte range showed a different pattern. The male group had significandy lower leucocyte and neutrophil counts $\left(12.0 \times 10^{9} / 1\right.$ wersus $14.3 \times 10^{9} / 1$ and neutrophil counts $5.9 \times 109 / 1$ versus $7.4 \times 10 \% / 1$ respectively). The lymphocyte, monocyte, eosinophil and basophil counts showed no differences.

These variables showed no significant differences in female and male newborns of non-smoking mothers. Male newborns of smoking mothers showed lower toral lencocyte counts and neutrophil counts than female newborns of smoking mothers. The other

Table 1. Comparison of the median values of the erythrocyte, reticulocyte and leucocyte variables in cord blood of the total group of female newborns of non-smoking $(n=46)$ and smoking $(n=29)$ mothers and of male newborn of non-smoking $(n=41)$ and smoking $(n=23)$ morhers. Only significantly different values are shown

\begin{tabular}{|c|c|c|c|}
\hline & $\begin{array}{l}\text { Total group of } \\
\text { male newborns }\end{array}$ & $\begin{array}{l}\text { Total group of } \\
\text { female newborns }\end{array}$ & Significance \\
\hline & $\begin{array}{l}\text { Modian } \\
(25-75 \text { perc. })\end{array}$ & $\begin{array}{l}\text { Median } \\
(25-75 \text { pere) }\end{array}$ & p-value \\
\hline$M F R(\%)$ & $\begin{array}{l}14.7 \\
(12.9-16.6)\end{array}$ & $\begin{array}{l}13.0 \\
(11.5-14.9)\end{array}$ & 0.014 \\
\hline$R D W-C V(\%)$ & $\begin{array}{l}17.2 \\
(16.2 \cdot 18.1)\end{array}$ & $\begin{array}{l}16.4 \\
(15.9-17.1)\end{array}$ & 0.008 \\
\hline WBC $\left(10^{\circ} / 1\right)$ & $\begin{array}{l}12.0 \\
(10.4-15.2)\end{array}$ & $\begin{array}{l}14.3 \\
(12.4-1.6 .8)\end{array}$ & 0.005 \\
\hline $\operatorname{NEUT}\left(10^{\%} / 1\right)$ & $\begin{array}{l}5.9 \\
(4.5-8.0)\end{array}$ & $\begin{array}{l}7.4 \\
(5.6-8.9)\end{array}$ & 0.009 \\
\hline
\end{tabular}

HFR = high fluorescence racio, RDW-CV = red blood cell distriburion width coefficient of variation, WBC = white blood cell. NEUT $=$ neurcophilic granulocytes 
Table 2. Comparison of the median values of the lewcocyte variables in cord blood of male newboms of non-smoking $(n=41)$ and smoking $(n=23)$ mothers. Only significan differences are shown

\begin{tabular}{|c|c|c|c|}
\hline & $\begin{array}{l}\text { Toral group of male } \\
\text { newborns of non-smokers }\end{array}$ & $\begin{array}{l}\text { Toral group of male } \\
\text { newborns of smokers }\end{array}$ & Significance \\
\hline & $\begin{array}{l}\text { Median } \\
(25-75 \text { pere) }\end{array}$ & $\begin{array}{l}\text { Median } \\
(25-75 \text { pere) }\end{array}$ & p-xalue \\
\hline $\mathrm{WBC}\left(10^{\circ} / 1\right)$ & $\begin{array}{l}12.9 \\
(11.2-15.8)\end{array}$ & $\begin{array}{l}10.7 \\
(8.9-12.7)\end{array}$ & 0.013 \\
\hline NEUT $\left(10^{9} / 1\right)$ & $\begin{array}{l}6.5 \\
(5.3-8.3)\end{array}$ & $\begin{array}{l}5.1 \\
(3.7-6.5)\end{array}$ & 0.018 \\
\hline
\end{tabular}

WBC $=$ white blood cell, NEUT = neutrophilic granulocytes

variables were not significantly different. No differences were found when comparing these vallues in female newborns of smoking and non-smoking mothers. Comparison of the leucocyte counts in cord blood of male newborns of non-smoking $(n=41)$ and smoking $(\mathrm{n}=23)$ mothers is shown in Table 2 . The erychrocyte, reticulocyte, thrombocyte counts and indices in both groups were almost identical. In cord blood from male newborns of smoking women, total white cell counts and neutrophil counts were significantly lower compared with values in cord blood from male newborns of nonsmokers. The median value for the white cells of male newborns of smoking mothers was $10.7 \times 10^{2} / \mathrm{l}$ compared with $12.9 \times 10^{9} / 1$ in male newborns of non-smokers. The median value for the neurrophil count in the group of newborns of smoking mothers was $6.5 \times 10^{9} / 1$ compared with $5.1 \times 10^{9} / 1$ in the group of newborns of non-smokers.

\section{Discussion}

Several animal studies have demonstrated that prenaral nicotine exposure affects male and female offspring differenty. Peters and Tang 21 found that prenatal nicotine trearment of dogs reduced both the number of male pups born and male birth weight; females were not significantly affected. Riesenfeld ${ }^{22}$ found that the body weight of male rars was reduced significantly more than that of female rats after prenatal nicocine exposure. Several studies investigating the effects of maternal smoking on fetal growth included sex-dependent effects. Ravenholt and Levinski ${ }^{23}$ examined birth weight in 1,096 infants born to mothers who smoked regularly. There was a negative correlation becween the number of cigarerres smoked and the proportion of males among live offspring. Wertelecki et al ${ }^{18}$ analysed birth weight and length of 925 newborns whose mothers had smoked during pregnancy. Male full-rerm neonates whose mothers smoked 
more than 10 cigarettes per day weighed $110 \mathrm{~g}$ less and were $1.1 \mathrm{~cm}$ shorter than those born to non-smoking mothers. The weight and length of the female newborns were not influenced by smoking.

In the present study the erythrocyre, reticulocyte and platelet ranges were not significantly influenced by smoking or gender and this was a significant finding. The white cell and neurrophil counts in cord blood were significantly decreased in male newborns of smoking mothers compared to those of non-smoking mothers and female newborns of smokers. Nicorine is known to have a direct toxic effect on neutrophils. 16

The present srudy suggests that male newborns are more affected than females when hacmatological variables in cord blood of male and female newborns of smoking and non-smoking morhers are compared. The consequence of the decrease in the rotal white cell and the neurrophil counts might be a reduction in resistance to infection in the male newborn infant of the smoking mother ${ }^{24,25}$ and this may persist throughout the neonaral period. ${ }^{26}$ Neonates of smoking mothers tend to have higher rates of hospital admissions for bronchitis and pneumonia. ${ }^{27}$ The present study suggests that male newborns of smoking morhers are more at risk of postnatal infections. Although more than 40 variables have been tested for staristical significance between the sexes and some differences might have occurred by chance, it seems desirable to increase the awareness of gender-specific sensitivity to cigarette smoke and to report such findings more systematically.

Acknowledgements: The authors thank Dr. B. Davies for revision of the manuscript.

\section{References}

1. Pipers L, Whadimiroff JW, MeGhic IS. Bom N. Acure effec of maternal smoking on the matcmal and lecal andovascular system. Early Hum Dev 1984:10:95-105

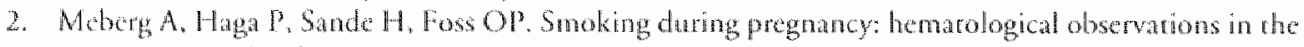
newtrom. Acta Pacdiatr Sond 1979;68:731-4

3. Kutuden A. Maremal smoking and the bilimbin concentration in the first retec days of life. Etar) Obser Ciynecol Reprod Brol 1991;40:123-7

4. Iins E, Matrai A. Schmolal C. Magyarosy 1. Dose-effect relationship berween snoking and blood theology. Br I Hacmatol 1987;65:485-7

5. Gam SM, Shaw HA. MCCabo KD. Effec of natremal smoking on hemoglobins and hematocrits of the newbon. Am I Cten Nurr 1978:31:557-8

6. Linderkamp O. Stadk A. Zilow EP. Blood viseosiry and oprimal hematocrit in preterm and full term neonate in 50- 10500 michometer whes. Bediat Res 1992:32:97-102

7. Hsich C. Clarke G. Adey D. Gouchi MN Smoking in pregnancy: relevance of maternal screening tests on fetal outcome. Fur J Obstex Gyneol Reprod Biol 1984:16:403-10

8. Peter TI. Golding J. Linwence CJ, Fryer JG, Chamberlain GV. Burter NR. Factors assochated wirh delayed onset of regular pespiration, Early Hum Dev $1984: 9: 209-23$

9. Narye RL. Eefects of maternal cigaretre smoking on the fecus and placenta. Br J Obster Gynaecol $1078: 85: 732-7$ 
10. Knornerus IA, Delgado LR, Knipschild PG. Essed GG, Smits F. Hatmatologie parameren and pregnancy outcome. A prospecrive cohor sudy in the third rimester. J Clin Epidemol 1990:43:461-6

11. Tell GS, Grimm RH Jr, Vellar OD. Theodorsen L. The relationship of white cell count placter coun, and hematocrit ro cigaretre smoking in adolescents: the Oslo Youth Srudy. Circulation 1985:72:971 4

12. Anchony HM. Reactive changes in the blood of smokers and the development of atreral discases and COPD, a review: evidence of associations between changes and subsequen discase with implications for the evaluation of hamful effects of cigarencs, and for suscepribility to the chronic effects of inhaled poltutants. Rev Environ Healh 1989:8:25-86

13. Eisen ME, Hammond EC. The effer of smoking on packed cell wolume, red cell conts, thatemoghobin and platelet counts. Can Med Assoc $1956,75: 520-3$

14. Meberg A. Halworsen S. Transitory thrombocytopenia in small-fordate infanes, and in newhorn mice exposed to hypobaric hypoxia, cigarette smoke and $\mathrm{CO}$ gas intatanion during pregnancy. Proc Eutop Soc Paediatr Res Annual Mecring, Turku 1978:58

15. Lemes GR, Donofro KH. Passive smoking: the medical and economic issues. An I Med 1992:93:385-425

16. Weinberg J, Zimmerberg B, Sonderegger TB. Gender-specific effecs of perinatal exposure co alcohol and orher drugs. The John Hopkins Universiry press 1992:51-89

17. Litle RE, Sing CF. Generic and environmental influences on human birth weight. Am I Hum Genet $1987: 40: 512-26$

18. Werelecki W, Hoff C, Zansky S. Maternal smoking: grater effecr on males, fetal tobaco syndrome? Teratology $1987 ; 35: 317-20$.

19. Ockene JK, Hosmer DW, Willans JW, Goidberg R!, Ockene 1S, Raia TJ 3d. Factura related to patien smoking status. Am I Public Health 1987,77:356-7

20. Herkner KR, Büch A, Muhl, Newbauer S. Herkner C. Reticulocyce councing and maturiry grading in pediatrics using the Sysmex R-1000 auromated reviculacyte analyser. Sysmox In / 1992:2:4.49

21. Peters DA, Tang $S$. Sex-dependent biological changes following prenatal nicorine exposire in the rat. Pharmacol Biochem Behav 1982:17:1077-82

22. Riesenfeld A. Growth-depressing effects of alcohol and nicorine in two strins of tats. Acra Anat Base $1985 ; 122: 18-24$

23. Ravenholt RT, Levinski MJ. Smoking during pregnancy. Lancer 1965;1:961

24. Smith JR, Landaw SA. Smokers' polycythemia. N Engl J Med 1978;2986-10

25. Harrson $\mathrm{KI}$. The effect of maternal smoking on neonatal leucocytes. Aust $\mathrm{N} Z \mathrm{Z}$ Obstec Gynacol $1979 ; 19: 160-8$

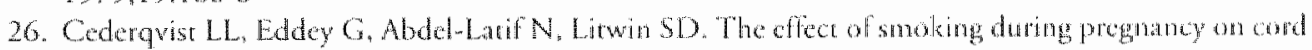
blood and matermal serum inmunghobulin lewels. Am J Otsure Gynecol 1984:1/48(8):1123-6

27. Harlap S, Davics AM. Infant admissions to hospical and maternil smoking hance 1974:1:529-32 



\section{Chapter 11}

\section{On haemostasis in newborns of smoking and non-smoking mothers}

Patricia EAM Mercelina-Roumans', JMH Ubachs", JWJ wan Wersch ${ }^{2}$

From the Deparment of Obstetrics and Gynaecology ${ }^{3}$, and the Depanment of Haematology ${ }^{2}$, De Wever Hospital, Heerlem. The Netherlands. 


\section{Abstract}

OBIECTIVE: To determine the effect of stroking during pregnancy on neonatal haewostasis. STUDY DESIGN: Venous blood samples of 26 newborns of smoking and 25 newboms of non-smoking mothers were obtained from the clamped umbilical cord immediately afier birth. Prothrombin fragment $1+2$, throwbin-antithrombin III complex, plasmin- $\mathrm{O}_{2}-\mathrm{an}-$ tiplasmin complex and D-dimer levels were determined to assess activation of coagulation and fibrinolysis. Cotinine wals medsured in all neonates to objectivate cigarette smoke exposture.

The Mann-Whitney-U test was used to compare the differences between the values of the parameters of coagulation and fibrinolysis in the two groups at the $p<0.05$ level.

RESULTS: The median values of prothrombin fragment $1+2$ and thrombin-anti-thrombin III complex in nowborns exposed to tobacco smake in utero did not differ from newborns who were not exposed. Nor were the markers of fibrinalysis, plasmin- $\alpha_{2}$-antiplasmin complex and D-dimer letels, influenced by tobacco smoke exposure.

CONCLUSION: The balance between the components of coagulation and fibrinolytic pathways in neorates is not disturbed by maternal smoking.

Blood fluidity is maintained by the balance between the components of coagulation and fibrinolysis. After activation of the extrinsic and the intrinsic pathway prothrombin is formed, which converts to thrombin. Part of this thrombin forms a complex with antithrombin III (AT III), resulting in the coagulation activation marker thrombin-anvithrombin III complex (TAT III). The remaining free thrombin leads to the formation of fibrin, which thas to be degraded by fibrinolysis. For this purpose, plasminogen is converted into plasmin. Plasmin then degrades fibrin to D-dimer fragments, which reflects the activation of fibrinolysis (Fig. 1). This system is similar in newborns and adults, bur the concentrations of several coagulation proteins differ in the newborn and are dependent on the gestational and postmatal age of the infant. ${ }^{1-3}$ The generation of thrombin is decreased by approximately $50 \%$ in the newborn compared to the adul $\mathrm{t}^{4,5}$ and at the time of birth. AT 1 I] levels are approximately half adult vallues. ${ }^{6}$ Most clotring factor levels in newborns are also lower than in adults? The same is true for the fibrinolytic factors: the concentration of plasminogen is approximately $50 \%$ of the adult value. ${ }^{7}$ On the other hand an important inhibitor of plasmin, $\alpha_{2}$-anriplasmin, is relatively high wirh $85 \%$ of the adult value. ${ }^{8}$ up to now, the reason for the lower levels of these plasma proteins in neonates, as compared to the adult norm, is not clear and further studies are needed to elucidate the physiological background. Besides, the existing data on normal values for coagulation and fibrinolysis for newborns are incomplete and heterogeneous with regard to the quality of patient definition, specimen colkction and tesring methods. Moreover, the influence of smoking on the mentioned parameters hats nor been accounred for, although smoking can affect the haemostatic system. Cigarette smoking during pregnancy is associated with a well-documented 
increase in perinatal moralicy and morbidity rates.9.10 Spinillo et all found that maternal smoking in pregnancy increases the risk of in tracranial haemorthage in pretern infants.

The present study was performed with a double purpose. First, to see if usable reference values of paramerers of coagularion and fibrinolysis for newborns were obtainable. Secondly, to investigate the influence of smoking during pregnancy on hacmostasis in newboms. To monitor coagulation activation the levels of prothrombin fragment $\mathbb{1}+2$ $(\mathrm{F} 1+2)^{12}$, and TAT II ${ }^{13}$, were measured. Plasmin- $\alpha_{2}$-antiplasmin complex (PAP) and D-dimer levels were determined in order to assess fibrinolysis acrivarion.

\section{Subjects and methods}

Seventy-two pregnant women, consecutively atrending the deparment of Obsterics berween April and June 1995 in the De Wever Hospital, Heerlen, The Netherlands were asked to participate in the study. None of the women refused. All women gave their informed consent. The duration of pregnancy was based on the last menstrual dare and ultrasound determinations between 8 and 14 weeks. Exclusion criteria were a diastolic blood pressure $\geq 90 \mathrm{mmHg}$ at the beginning or during pregnancy, an endocrine discase, at coagularion disorder, the use of medication known ro interfere with the haemostatic system, or the history of any of these diseases, solutio placentae or immarure or premature delivery. Twenty-one women had to be exchded for these reasons. All neonates were born at term (> 37 weeks) and were declared healthy after physical examination.

The number of cigarertes smoked per day by the mothers was an estimation by the paticnt, in most cases confirmed by her partner. Cotinine, ancorine specific metabolice and one of the most accurate biochemical assessmenes of nicotine exposure ${ }^{14}$, was measured in all neonates to objecrivate cigaretre smoke exposure. The last cigarcte was smoked whin 15 hbeforedelivery. The corinine masurementsonfinmed the women"s smoking habits. In the end 26 newborns of smoking and 25 newborns of non-smoking mothers were induded in the study. The basic chatreristics of the mothers and their offpring are summarized in Table 1.

Venous blood samples of the newborns were obtained from the clamped umbilical cord inmediately after birth. All parameters of haemostasis were detemined in citared plasma which was prepared by centrifugation of a mixture of 9 volumes freshly drawn blood with one volume trisodium citrate $(0.11 \mathrm{~mol} / \mathrm{l})$ for 30 minutes $(1600 \mathrm{~g})$ at $250 \mathrm{C}$. The plasma was stored at $-70^{\circ} \mathrm{C}$ in plastic tubes and thawed with rap water at $37^{\circ} \mathrm{C}$ for 5 minutes betore serial analysis. F $1+2$, TAT III and PAP were assessed in plasma using an Elisa test of Behring Corporation (Marburg, Germany). The Dudimer fibrin degradation products were measured by means of the Elisa rest of Bochringer Mannheim, Cermany. 
Table 1. Basic chanactistics of the mothers and of their newborns

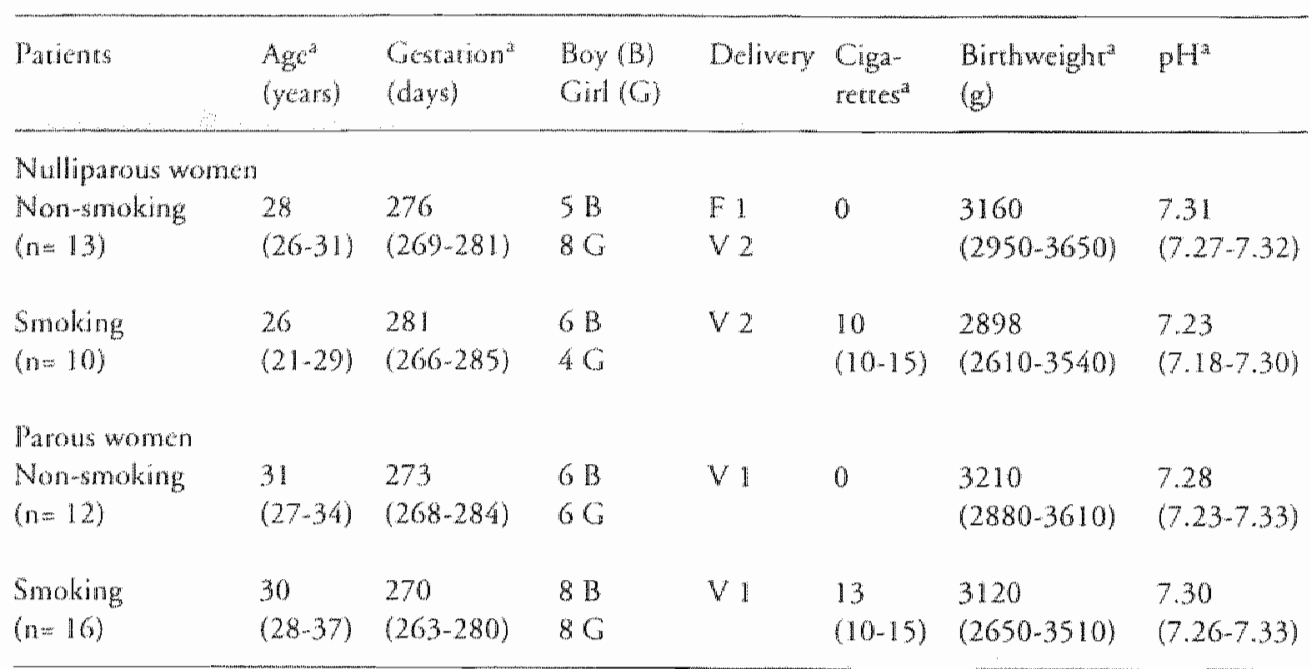

"Values represent median (IR); $F=$ forceps delivery, $V=$ vacuum exracrion.

"Table 2. Parameters of congulation and fibrinolysis activation in newborns of smoking and non-smoking mothers ${ }^{\mathrm{t}}$

\begin{tabular}{|c|c|c|c|c|}
\hline & $\begin{array}{l}\text { Newborns of } \\
\text { smokers } \\
(n=26)\end{array}$ & $\begin{array}{l}\text { Newboms } \\
\text { of non-smokers } \\
(n=25)\end{array}$ & Significance & $\begin{array}{l}\text { Laboratory reference } \\
\text { range for newborns }\end{array}$ \\
\hline & $\begin{array}{l}\text { Median } \\
(25-75 \text { pere })\end{array}$ & $\begin{array}{l}\text { Median } \\
(25-75 \text { perc })\end{array}$ & p-valuét & $(2.5-97.5$ perc $)$ \\
\hline$[1+2(\mathrm{nmol} / \mathrm{l})$ & $\begin{array}{l}1.5 \\
(1.2-1.9)\end{array}$ & $\begin{array}{l}1.7 \\
(1.3-2.5)\end{array}$ & 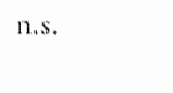 & $0.75-6.40$ \\
\hline TAT-HI $(\mu \mathrm{g})$ & $\begin{array}{l}10.1 \\
(5.4-14.0)\end{array}$ & $\begin{array}{l}7.3 \\
(6.0-25.0)\end{array}$ & n.s. & $1.7 \cdot 75$ \\
\hline $\operatorname{PAP}(\mu \mathrm{g} / 1)$ & $\begin{array}{l}190 \\
(145-420)\end{array}$ & $\begin{array}{l}360 \\
(165-660)\end{array}$ & n.s. & $66-1250$ \\
\hline D-dimer $(\mu \mathrm{g} / \mathrm{mb})$ & $\begin{array}{l}306 \\
(243-582)\end{array}$ & $\begin{array}{l}400 \\
(29-922)\end{array}$ & n.s. & $177-1651$ \\
\hline D-dimed TAT III rario & $\begin{array}{l}28.4 \\
(16.1-41.4)\end{array}$ & $\begin{array}{l}34.9 \\
(25.6-49.1)\end{array}$ & n.s. & $2.5-68.9$ \\
\hline
\end{tabular}

\footnotetext{
"Abbreviations are defined in the texe.
} 


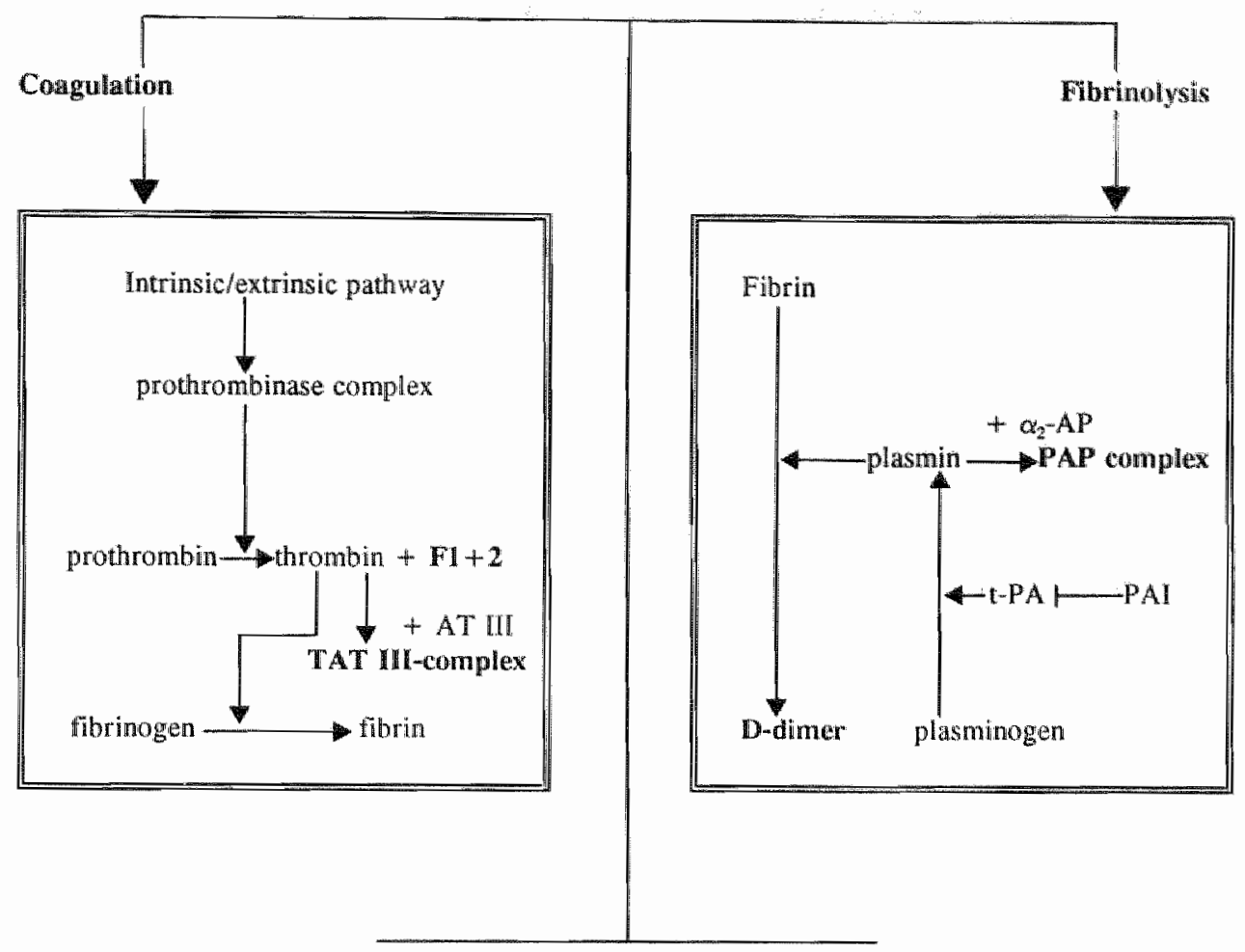

Fig 1. Homeostasis of the hamostatic system

Cornine concentrations were measured by gaschromatography 15 . The detection limit for cotinine was $10 \mu \mathrm{g} / \mathrm{ml}$.

The Mann-Whitney-U test was used to compare the differences berween the values of the parameters of coagularion and fibrinolysis in the rwo groups at the $p<0.05$ level.

\section{Results}

Table 2 shows the median values of F $1+2$ and TAT III in newborns exposed to tobacco smoke in utero and in those who were not. Both parameters showed the same levels in the rwo groups. In the same Table the rwo markers of fibrinolysis are shown. PAP nor D-dimer levels were influenced by robacco smoke exposure. While comparing cach individual measurement of these four parameters it was found that all F1+2, TAT, PAP and D-dimer values in the neonates of smokers were higher than the lowest values of these parameters in neonates of non-smokers. The D-dimer/TAT III ravio, which can 
be seen as an indicator of the balance berween fibrinolysis and coagulation, was the same in neonates of smokers and non-smokers (respectively 34.9 in the non-smokers and 28.4 in the smokers) (Table 2 ). The reference ranges $(2.5-97.5$ perc) of these parameters are given in the last column of Table 2 .

\section{Discussion}

Knowledge of the normal development of the neonatal haemostatic system is necessary to interpret thrombotic and haemorthagic episodes in the newborn. Coagulation factors are known to be changing constantly over the first months of life. 1,16 These changes are not only dependent upon the postnatal age of the infant but also upon the gestational age, 116 The prothrombin time (PT) and partial thromboplastin time (PTT) are often used to detect general abnormalities in the haemostatic system. Various reference values for newborns have been published for these tests. ${ }^{17,18}$ Since normal walues for the PTT and $\mathrm{PT}$ vary according to reagents used and there is no complete agreement on normal standards in adults, it is not possible ro list age related nomal values except as they relate to a single laboratory study. 19 Recenty, assays for the measurement of activation products of the coagulation and fibrinolytic parhways have been developed. 20

Conversion of prothrombin to thrombin, mediated by the prothrombinase complex (factor $\mathrm{Xa}, \mathrm{Va}$, calcium and phospholipid) is the key event in blood coagulation and produces a peptide designated $\mathrm{F} 1+2$. The $\mathrm{F} 1+2$ plasma level can be regarded as an indicator of the acrivity of the prothrombinase complex. ${ }^{21}$ Reference values of $F 1+2$ in newborns have not been published before.

Once formed in plasma, thrombin is inhibited by a naturally occurring antiproreinase, antithrombin III, with formation of a complex of TAT III. ${ }^{22}$ AT-III levels in newborns are dependent on gestational age and birth weight. ${ }^{23}$ The levels increase until term to abour $50 \%$ of the adult norm. 24 Due to very low AT-III levels, newborns small for gestarional age have an additional risk for thrombosis; since the AT-III pool of their plasma is small, rhey are prone to dysregulation in every situation of consumprion. ${ }^{24}$ Muntean et al 25 reporced high TAT III levels shorty after birth in healthy term infants. He also observed that TAT III levels decreased to near normal aduit values within 24 hours.

Plasmin acrivity can be assessed by measuring PAP. 26 There are no published reference data for $P A P$ in neonares. $D$-dimers ( $D$-fragments of fibrinogen and fibrin) are produced during plasmin mediated lysis of fibrin. ${ }^{27}$ In adults the concentration of D-dimers is the most sensitive marker for monitoring the activity of intravascular coagulation. 28.29 Similar to TAT III, D-dimer levels were found to be high immediately after birch, returning to near normal values for adults within 24 hours afrer birch. ${ }^{25,30}$

Our findings in healthy cerm infants born afrer an uncomplicated pregnancy are consistent with a hypercoagulable state. TAT III levels were high immediately after birth. 
The finding of the equally high D-dimer values indicate that fibrin formarion is counterregulated by fibrinolytic acriviry. The D-dimedTAT III ratio illustrates this. The large spreading of the reference values for these markers of coagulation and fibrinolysis makes them unusable for clinical pracrice.

Cigarette smoking during pregnancy is associated with an increase in perinatal morbidity and mortality. 9,10 In pregnant women who smoke the activated coagulation process is not counterbalanced by an increase of fibrinolysis, as is the case in non-smoking pregnant women. ${ }^{31}$ Unlike their smoking mothers, neonates do not show a lack of balance berween fibrinolysis and coagularion. In fact, comparing the four markers of haemostasis in newborns of smokers and non-smokers no differences were found.

In conclusion, the balance between the components of coagulation and fibrinolytic pathways in neonates is not disturbed by maternal smoking. A large population is now being studied to obtain usable reference values.

\section{References}

1. Andrew M, Paes B, Milner R, Johnston M. Mirchell L. Tollefsen DM, er al. Development of the human coagulation sysern in the full-term infant. Blood 1987:70:165-72

2. Bleyer WA. Hakami N, Shepand TH. The development of hemostasis in the human ferus and newborn infant. I Pediatr 1971;79:838-53

3. Corrigan JJ Jr. Neonatal thrombosis and the thrombolytic system:pathophysiology and therapy. Am I Pediatr Hematol Oncol 1988;10:83-91

4. Lammle B. Griffin $\mathrm{JH}$. Formation of the fibrin clot: the balance of procoagulant and inhibitory factors. Cin Haemarol 1985:14:281-342

5. Schmidt B, Ofosu FA, Mirchell L, Brooker LA, Andrew M. Ancicoagulant effecrs of heparin in neonatal plasma. Pedian Res 1989;25:405-8

6. Schmide B. Mirchell L, Ofosa FA, Andrew M. Alpha-2-macroglobulin is an imporante progressive inhibitor of thrombin in neonat and intan plasma. Thromb Hacmost 1989:62: 1076-7

7. Corrigan IJ Jr. Nconatal thrombosis and rhe thrombolyric sysecm: pathophysiology and therapy. An Pediatr Hematol Oncol 1988:1083-91

8. Corrigan J] Jr, Slecth J), Jeter M. Lox CD. Newborn's fbrinolytic mechanism: componons and plasmin generarion. An I Henatol 1989;32:273-8

9. Meyer MB, Joras BS, Tonascia JA. Perinatal events associared with matemal smoking during pregnancy. Am I Epidemiol 1976:103:464-76

10. Mclntosh ID. Smoking and pregnancy: II Offpring risks. Public Heath Rey 1984;12:29-63

11. Spinillo A, Omero A, Sronati M. Prazzi G, Jasci A, Rondini G. Epidemiologic association between maternal smoking doring pregnancy and intracranial themorthage in pretem infancs. I Pediat $1995: 127: 472-7$

12. Lau HK, Rosenberg 15, Beeler DL, Rosenberg RD. The isolation and characterization of a specife antibody popularion direced agains the prohrombinacrivation framents $F 2$ and $F 1+2$. I Binf Chom $1979,254: 8751-61$

13. Hoek JA, Sunk A, ren Care JW, Lamping RJ, Berends F, Borm JJ Laboratory and dimeal evaluation of an assay of thrombin-antithrombin II complexes in plasma. Clin Chem 1988;34:2058-62

14. Patrick DL, Cheadle A. Thompson DC, Dieh P. Koppell T, Kinne S. The walidity of selferenced smoking: a review and mera-anatysis. An J Public Health 1994:84: $1086-93$ 
15. Jacob P 3d, Wilson M, Bonowin NL. Improved gas chromatographic method for the determinaton of aicotine and cornine in biologic fuids. J Chromatogr 1981:222:61-70

16. Androw M. Schmid B. The coagularion sysem in the rewborn infanc. Anticoagulane and thrombolyric therapy in the newborn. In: Suzuki S. Hathaway WE, Bonnar J, Suror AH, editors Perinaral thrombosis and hemostasis. Tokyo, Springer-Ventag 1991:113-23

17. Corrigan J] Jir. Nomal haemontasis in fetus and newbom coagularion. In: Polin RA. Fox WW edicors. Nconalal and feal medicine. Physiology and pathophysiology. New York, Grune and Sratron, 1991

18. Harhaway Wontar J. Hemostacic disorder of the pregnant women and newborn infant. Elsevier Science Publishing Co., New York. 1987.

19. Hahaway WE. Corrigan J. Report of scientific and standardization subcommirtee of neonatal Hacmostasis normal coagulation data for fetuses and newborn infants.

20. Boisclair MD, Ireland H. Lane DA. Assesment of hypercoagulable states by measurement of activation fragments and peprides. Blood Rey 1990;4:25-40

21. Bruhn HD, Conard J, Manucci M, Monteagudo J, Pelzer H, Reverter JC, et al. Mulncentric evaluation of a new assay for prothrombin fragment $F 1+2$ determination. Thromb Haemost 1992;68:413-7

22. Teirel JM. Bawer KA, Lau HK, Rosenberg RD. Studies of the prothrombin activation parhway urilizing radiommunoasays for the $\mathrm{F} 2 / \mathrm{F} 1+2$ fragment and thrombin-antithrombin complex. Blood $1982 ; 59: 108697$

23. Percr M, ten Cate JW, Koo LH Breederveld C. Persisten antimombin III deficiency: risk factor for Whromboembolic complicarions in neonares small for gestational age. I Pediatr 1984:105:310-4

24. Karges HE. AT III in pregnancy and newborn infants. In: Suzuki S. Hathaway WE, Bonnar I, Suror AH, ediror: Perinatal thrombosis and hacmostasis. $47-55$

25. Muntean W, Danda M, Rosegger H. Thrombin-antithrombin III complex and D-dimer in neonates: Signs of thrombin generation during birth. In: Suzuki S. Hathaway WE, Bonnar I, Sutor AH, editors: Perinatal thrombosis and hamomostas. Tokyo, Springer-Verlag 1991

26. Kario K, Marsuo T, Kodama K, Marsuo M, Yamamoro K. Kobayashi H. Inbalance berween thrombin and plasmin activity in disseminated inmavascular coagularion. Assessment by the thrombin-anrithrombin III complex/plasmin-alpha-2-antiplasmin complex ratio. Haemostasis 1.992,22:179-86

27. Lane DA. Preston FE, VanRoss ME, Kakliar VV. Characterization of semm fibrinogen and fibrin Fragments produced during disseminared intravascular coagulation. Br. Haematol 1978;40:609-15

28. Gaffney PJ. Perry MJ. Unreliability of current serum fibrin degradation product (FDP) assays. Thromb Hatmos $198553,301-2$

20. Greenbers CS, Devine DV, MCCrae KM. Mcasurement of plasma fibrin D-dimer levels with dhe use: of a monoclonal antibody coupicd on latex beads. Am J Clin Parhol 1987; 87:94-100

30. Hudson IR. Gibsen BE, Brownlic I. Holland BM, Tumet TL. Webber RG. Increased concentrations of D-dimers in newhorn infants. Arch Dis Child 1990,65:383-4

31. Merchina-Roumans PEAM, Ubachs JMH, wan W/ersch JWJ. Coagularion and fibrinolysis in smoking and non-smoking pregnant women. Br J Obsrer Gynacolin press 


\section{Chapter 12}

\section{General discussion}

The mechanisms by which cigarette smoking has a negative effect on pregnancy and pregnancy ourcome are complex and multifactorial. The aim of this study has been to raise a corner of the veil by investigating whether these effects are mediated or reflected by changes in haematological variables in smoking pregnant women and/or their offspring.

During the course of this study the usual pitfalls in clinical research had to be confronted. First, smoking and non-smoking individuals live differently. It is known from studies on smoking and cardiovascular disease that smokers do not live as healthily as their non-smoking counterparts. ${ }^{1,2}$ Secondly, this study was done in a large teaching hospital. The patients were seen by various doctors and were not all checked in the same four stages. Consequently, a careful interpreration should be made regarding the longirudinal changes in haematological parameters during the pregnancies of both the smoking and the non-smoking groups. A second study has now been initiated to provide more information on this subject.

Concentrations of nicotine and its metabolite cotinine were measured in the plasma of pregnant women to confirm their smoking habits. The results of these tests have shown that cotinine is more useful than nicotine in discriminating between non-smokers, light and heavy smokers. "These results also showed that all the women gave truthful estimates of their smoking habits. Cotinine measurements were carried our in plasma of neonates of smokers and non-smokers and in neonatal plasma in parallel to maternal plasmat. It became clear that cotinine is easily transferred to the fetal compartment. However, there seems to be a threshold of around 10 cigarettes per day. The latter finding could imply that the fetuses/ neonates of light smokers are not affected as far as corinine is concerned. Nevertheless, the amounts transmitted of the other 3600 compounds in cigarette smoke are still unclear.

Some remarks should be made on the effect of smoking on blood cells and cell indices. Smoking in pregnancy leads to a lower erythrocyte count and a higher MCV. A lower erythrocyte count means less oxygen transport, whereas the transport of large erythrocytes is more difficule in constricted vessels. The production of PG $\mathrm{I}_{2}$ in the umbilical cord is decreased by smoking, causing a constriction of the vessels in the placenta. ${ }^{3}$ Because of a low blood $\mathrm{pO}_{2}$ the fetus is hypoxic in utero in comparison to postnatal life. However, normally the ferus has access to the necessary amount of oxygen. 
Two major adaptations make this possible. First, the haemoglobin of fetal red blood cells has high affiniry for oxygen. This property enables these cells to become highly sarurated with oxygen as they circulate through the placenta. Secondly, the Eetus has a high cardiac outpur in relation to its body size and metabolite rate. It is unlikely that this physiological state of hypoxia will be disturbed by maternal smoking. However, the effect of smoking could be of paramount importance during stressful episodes.

Smoking during pregnancy has an additive enhancing effect on the total leucocyte count, mainly due to an increase of neutrophils, monocytes and lymphocyres. This finding raises questions regarding the effects of smoking on immunity in pregnancy. Are lymphocyte subsets modified by smoking during pregnancy? And is humoral immunity an issue? Further research in this field might be rewarding.

The effect of smoking on the haemostatic system in pregnant women is interesting. The finding that the balance between coagularion and fibrinolysis is discurbed in this group can explain several obstetrical problems encountered in smokers, e.g. growth retardation, placental infarction and intratuterine death.

Smoking during pregnancy has a negative effect on the neutrophil count in newborns, especially male newborns. This might be an explanation for the enhanced incidence of bronchitis and pneumonia in children of smoking mothers. In adults, smoking can be considered as a chronic inflammatory disorder of the lower airways. "Tissue injury may result from the action of degenerative enzymes, from such cells as neutrophils and monocytes. 5 In addition, oxidative injury from cells and from oxidants in smoke may participate in the pathogenesis of smoking-related lung diseases. ${ }^{6}$ Lung cancer represents the most striking risk imposed by cigaretre smoking. The cancer causing effects of cigarette snoking include the induction of carcinogen-acrivating enzymes and adduct formation with DNA, resulting in misteplication and mutation. 7 Smoking also exerts toxic effects that result in impaired mucociliary clearance, increased numbers of activated polymorphonuclear cell $\|_{S}$ and macrophages, producing neutrophil elastase and orher proteases, and decreased immunological responsiveness. 8 It remains to be investigated wherher smoke exposure in utero predisposes the newborn to lung cancer in later life. A cohort study performed by Pershagen et al. ${ }^{9}$ found no increase in overall cancer risk in children of mothers who smoked during their pregnancy. However, as the maximum follow up age was 5 years, further studies are needed to determine whether smoking during pregnancy induces malignancies in childhood or later life.

In the reticulocyte range the reticulocyte count itself was significantly lower in the smoking group whereas the reticulocyte subsets remained unchanged. The latter allow a more accurate cvaluation of the bone marrow activity chan the total reciculocyte count. $^{10}$ These resuls are remarkable as one would expect a stimularion of fetal erythropoiests as a reaction to a lower erychrocyte count in matemal smokers. The variables of the erythrocyte and thrombocyte counts were not different in cord blood of neonates who were exposed to smoke from that of those who were not. Thus, from a 
haemarological point of view the effect of smoking on the whole blood cell count of neonates is limited.

Another remarkable finding is that neonatal haemostasis is not discurbed by maternal smoking. However, coagulation and fibrinolysis seem to be on a higher level in neonates of smokers. A larger population is now being studied.

The present study has brought to lighr some of the haematological effects of smoking during pregnancy. On account of these findings counselling of women who smoke should have a high priority in antenatal care. Pregnant women who continue to smoke should be counselled to stop for their own health and the health of their unborn child. Future research should focus on whether cigarette smoking or smoke exposure can change the functional characteristics of the blood cells. Molecular biological investigations will be necessary to obtain insight in the individual effects of the numerous components of cigarette smoke.

\section{References}

1. Bruckert E, Jacob N, Lamaire L, Truffert J, Percheron F, Gennes de JL. Relationship becween smoking starts and serum lipids in a hyperlipedemic popularion and analysis of possible confounding fiactors. Clin Chem 1992;38: 1698-705

2. Burling TA, Singtecon EG, Bigelow GE, Baile WF, Gontieb SH. Smoking rollowing myocardial infarction: a critical review of the lirenature. Health Psychology 1984;3:83-6

3. Ahisten $G$, Ewald $U$, Tuvemo T. Macemal smoking reduces prostacy din formation in human umbilical arberies. Acra Obster Gynecol Scand 1986;65:645-9

4. McCusker K. Mechanisms of respitatony tissue injury from cigaretre smoking. Ann J Med 1992:93:18-21

5. Gadeck J, Pacht E. The protease-antiprotease balance within the human lung: implications for the pathogenesis of emphysemia. Lung 1990;5:552-64

6. Halliwell $\mathrm{B}_{3}$, Gutceridge JMC. Oxygen free radicals and iron in relarion to biology and medicine; some: problems and concepts. Arch Biodoem Biophys 1986;246:501-14

7. Carbone D. Smoking and cancer. Am J Med 1992.93:13-21

8. Bridges R, Hsich L. Effects of cigaretre smoke components on in virro chomotaxis of polymorphomuclear leukocytes. Infect Immun 1978;16:240-8

9. Pershagen G, Ericson A, Otterblad-Olausson P. Maremal smoking in pregnancy: does ir increase the risk of childhood cancer? Int Epictemiol 1992;21:1-5.

10. Castrota-Scanderbeg A, Pedrazxi G. Mercadant M, Staphane 1, Buterini A, Tzi G. Normal valucw of cotal reticulocytes and reviculocyte subsets in children and young aduls. Hacmatol 1992; 77,363-4 



\section{Chapter 13}

\section{Summary}

In the European community countries $36 \%$ of the inhabitants smoke. In the Netherlands $30 \%$ all women of reproductive age smoke, compared with $36 \%$ of men. Surveys of smoking during pregnancy have shown that the prevalence of smoking in this group of women is high. One-third of all pregnant women continue to smoke. Nicotine dependence is the most powerful driving force for continuing the habit.

In chapter 1 the pharmacology of nicotine and its metabolite cotinine, carbon monoxide and thiocyanate is described. Cotinine measurements perform best in discriminating smokers and non-smokers because of its long half life $(10-20 \mathrm{~h})$ and its specificity for tobacco smoke exposure. Cotinine concentrations in the plasma and milk of the mother and the plasma and urine of the infant reflect the smoking habits of mothers during pregnancy.

Next, the effect of smoking on blood cells and haemostasis is reviewed. Various reports have established that total white blood cell counts are significantly higher in smokers compared to non-smokers. This raise has been attributed mainly to monocyte release. It remains difficult to resolve whether smoking increases or decreases inflammatory cell responsiveness. Carbon monoxide binds to haemoglobin, replaces oxygen and thus produces hypoxaemia, which in the long term can cause polycythaemia in smokers. Considerable evidence has accumulated to link habitual smoking and polycythaemia. Cigarette smoke has been reported to induce platelet acrivation, an effect mediated mainly by nicotine, and to increase the platelet adhesion to the vessel wall. Aggregation of platelets is acutely increased by cigarette smoke.

Maremal smoking during pregnancy may create a condition of chronic hypoxia for the fetus. This can be the result of the replacement of oxyhaemoglobin by carboxy haemoglobin. Additionally, structural changes in the placenta as well as decreased placental blood flow may also impair the oxygen supply to the ferus. Increased haemoglobin and haematocrit levels have been reported in infants of smoking mothers.

Several lines of evidence suggest that smoking affects coagulation status as shown by higher plasma fibrinogen and thrombin-antithrombin III levels. Studies of fibrinolysis in smokers have shown variable results. Both an increase and a decrease in fibrinolysis have been reported.

The effects of smoking on pregnancy are numerous as listed further. Cigaretre smoking is associared with a dose-related reduction in fecundity and fertiliry. An increased risk 
of spontaneous abortion and antepartum haemorrhage has been described. An average decrease in birth weight of $200 \mathrm{~g}$ has been reported. The association between smoking and perinatal death and maternal smoking and childhood cancer is dispurable. Some tobacco relared dearhs are probably due to the increased risk of malformation. Children of mothers who smoke are admitted rwice as often to the hospiral for pulmonary problems.

The mechanisms by which cigarette smoking has a negative effect on pregnancy and pregnancy outcome are complex and multifactorial. The aim of this study was to inwestigate whether these effects are mediated or reflected by changes in haemarological variables in smoking pregnant women and/or their offspring. Consequently, the following objectives were pursued:

1. The effect of smoking on blood cells and cell indices in morhers (chapter 4, 5, 6, and 7) and their newborns (chapter 9).

2. The sex-related differences of nicotine exposure in neonates (chapter 10).

3. The simultaneous effects of smoking and pregnancy on haemostasis (chapter 8).

4. The haemostasis in neonates of smoking and non-smoking mothers (chapter 11).

5. The estimation of the degree of fetal exposure to the constiruents of cigarette smoke. For this purpose cotinine measurements were carried out in maternal blood plasma and cord blood plasma (chapter 3).

In chapter 2 the literature regarding smoking and reproduction is reviewed. Cigarette smoking is associated in women with a dose-relared reduction in fecundiry and fertility and in men with a reduction of semen quality. Smoking has a negative effect on pregnancy: increased rares of antepartum bleeding and placenta praevia have been described. Smoking is also associared with increases in the rates of spontaneous abortion, low birth weight, perinatal death, and sudden infant death. Some tobacco-related perinatal deatss are due to an increased risk of serious malformation. Children of mothers who smoke are admitred twice as often to the hospital for pulmonary problems. Sudics on marernal smoking and childhood cancer have proved inconclusive.

In chapter 3 cotinine is measured in smoking pregnant women and their infants. Tobacco smoke consists of more than 3600 different compounds. One of its chief pharmacologically active ingredients is nicotine of which $60 \%$ is metabolized to cotinine. Cotinine is the best available biochemical measure of nicorine consumprion beciuse it is specific for tobacco smoke exposure and it has a long $\mathrm{r}^{1 / 2}(10-20 \mathrm{~h})$.

In the present study nicotine and cotinine measurements were carried out in 25 smoking and 25 non-smoking healthy pregnant women. In all 25 non-smoking pregnant women nicotine and corinine levels were $<10 \mu \mathrm{g} / \mathrm{ml}$. Light smokers $(<10$ cigarettes $/$ day ) were found to have nicotine blood levels $<10 \mu \mathrm{g} / \mathrm{ml}$ and cotinine levels varying between 40 and $99 \mu \mathrm{g} / \mathrm{ml}$. Heary smokers ( $\geq 10$ cigarettes/day) had nicotine levels $<10 \mu \mathrm{gg} / \mathrm{ml}$, but high corinine levels varying from 1.15 to $199 \mu \mathrm{g} / \mathrm{ml}$. Cotinine measurements were carried out in 25 neonates of non-smoking mothers and in 34 neonates of smoking mothers. 
The mothers of 9 of these 34 newborns were included in the sudy to investigate the relacionship between maternal and neonatal cotinine concentrations. Cotinine levels in neonates of non-smokers and women who smoked less than 10 cigaretres/day were below the detection limit of $10 \mu \mathrm{g} / \mathrm{ml}$. Cotinine values in neonates whose mothers smoked $\geq$ 10 cigaretres/day were significantly higher than in those whose mothers smoked $\leq 10$ cigarettes/day, but significantly lower than in their mothers. There seems to be a threshold of around 10 cigarettes/day.

Cotinine measurements in the pregnant women confirm that corinine measurements are more useful than nicotine in discriminating non-smokers, light and heavy smokers. Cotinine concentrations were significandly lower in the neonates than in their mothers, but there was a strong positive linear relationship between maternal and neonatal cotinine concentrations.

In chapter 4 the leucocyte count is studied in 194 smoking and 518 non-smoking healthy pregnant women. Smoking in pregnancy appeared to have an additive enhancing effect on the already known total leucocyte increase in pregnancy. The leucocyte differential count in 105 smoking and 288 non-smoking pregnant women showed that the eosinophil and basophil count was not involved in the whire blood cell shift. The rise of the total leucocyte count was mainly due to an increase of neutrophils, monocytes and lymphocytes. The leucocytosis in the smoking pregnant women was dose-relared: significant upward jumps of the percentages of leucocytosis were observed between 12 and 15 cigarettes/day as well as between 19 and 20 cigaretres/day.

In chapter 5 the erythrocyte count and indices are compared in 247 non-smoking and 123 smoking healthy pregnant women at four different stages of pregnancy: 0-10, 11-20, $21-30$ and $31-40$ weeks. Blood samples were run on a Sysmex NE-8000. The erythrocyte count was significantly lower in smokers than in non-smokers $\left(3.86 \times 10^{12} / 1\right.$ versus 3.96 $\times 10^{12 / 1)}$ in the last ten weeks. Comparing the erythrocyte count at the beginning and the end of pregnancy there were significant lower values in both groups $\left(4.32 \times 10^{12 / 1}\right.$ to $3.96 \times 10^{12 / 1}$ in the non-smoking and $4.24 \times 10^{12 / 1}$ to $3.86 \times 10^{12 / 1}$ in the smoking group). The differences in the median HGB and HCT levels were neglectable. The MCV was significantly higher in women who smoked, as was the MCH (MCV $91 \mathrm{~A}$ and $\mathrm{MCH} 1.90 \mathrm{fmol}$ in the non-smoking versus $\mathrm{MCV} 94 \mathrm{fl}$ and $\mathrm{MCH} 1.95 \mathrm{fmol}$ in the smoking group) in the last ten wecks. Smoking in pregnancy leads to a lower erythrocyte count and a higher MCV which might create a hypoxic condition of the ferus.

In chapter 6 the reticulocyte count and its subfractions are compared in 247 non-smoking and 123 smoking healthy pregnant women at different stages of normal pregnancy. Blood samples were run on the Sysmex R-3000 reticulocyte counter. This instrument is able to provide precise reticulocyte counts. Furthermore, it estimates the maturity of reticulocytes by measuring the fuorescence intensity, a reflection of the RNA content of the cell. As the rericulocyres become older, their fluorescence (RNA content) decreases. The high fuorescence ratio is therefore a reflection of the most immature 
reticulocyte. The absolute reticulocyte count showed a trend to lower values in the snoking group throughout pregnancy, but this was only significant in the last ren weeks of gestation $\left(71.9 \times 10^{9} / 1\right.$ versus $\left.78.8 \times 10^{9} / 1\right)$. There was no difference between the low fluorescence, the medium fluorescence and the high fluorescence proporrions in the non-smoking and the smoking group. Both groups behaved similarly during pregnancy: there was a decrease of mature reticulocyres and a significant increase of more immature reticulocytes. These data show a moderate measurable effect of cigarette smoking on the reticulocyte count and the absence of an effect on the reviculocyte subsets.

In chapter 7 the platelet count and indices are compared in the same population. Most platelet studies have been confined to platelet counts in normal pregnancy, although the combination of platelet and platelet size paramerers as mean plateler volume (MPV), platelet distribution width (PDW) and platelercrit (PCT) mighe provide better insight in platelet biology during pregnancy. Blood samples were run on the Sysmex NE-8000. There was no significant difference berween the plarelet count in the rwo groups. In the non-smoking group, the plateler count showed a significant decrease with gestarional age $\left(287 \times 10^{9} / 1\right.$ to $\left.258 \times 10^{9} / 1\right)$. This was not the case in the smokers group. The MPV of the smokers was significantly lower than that of the non-smokers in the last ten weeks of pregnancy (10.4 $\mathrm{fl}$ versus $10.7 \mathrm{fl}$ ). The PDW and the PCT did not change under the influence of cigaretre smoking. The present study indicates that smoking during pregnancy does not affect platelet count and plateler indices in a clinically relevant way. In chapter 8 coagularion and fibrinolysis in smoking $(n=57)$ and non-smoking $(n=44)$ pregnant women are discussed. In order to investigate the simultaneous effects of smoking and pregnancy on haemostasis prothrombin fragment $1+2\left(F_{1} 1+2\right)$ and thrombin-antithrombin III (TAT III) (parameters of coagulation activation) and plasminogen, $\alpha_{2}$-antiplasmin and D-dimer levels (paramerers of fibrinolysis) were assessed. There was no indication of a reduction of fibrinolysis during normal pregnancy. Habicual smoking does nor have an addirive enhancing effect on the already activated coagulation process in pregnancy. However, smoking during pregnancy did lead to a reduction of fibrinolysis. In pregnant women who smoke the activated coagulation was not counterbalanced by an increase of fibrinolysis, as was the case in their non-smoking counterparts.

Chapter 9 deals with the effect of maternal smoking on neonaral cellular blood components. The values of whole blood cell count, leucocyte differential count, thrombocyte, erythrocyte and reticulocyte count were determined in cord blood of neonares of non-smoking $(n=89)$ and smoking $(n=53)$ mothers. The variables of the erythrocyte and thrombocyte count were not different in cord blood of neonates who were exposed to smoke and in those who were not. In the reticulocyte range the reticulocyte count was significantly lower in the smoking group, while the reticulocyte subsers remained srable. The neutrophils were significantly lower in cord blood of neonates of smoking mothers. The latrer finding might be an explanation for the enhanced incidence of postmatal infections seen in children of smoking mothers. 
In chapter 10 the same paramerers as in chapter 9 were assessed in cord blood of both male $(n=64)$ and female $(n=75)$ newborns of 87 non-smoking and 52 smoking mothers. Leucocytes and neutrophils in cord blood from male newborns of smokers were significantly lower than those in their female counterparts and in the male newborns of non-smokers. These data suggest that male newborns are more at risk of postnatal infections. Although more than 40 variables have been tested for statistical significance between the sexes and some differences might have occurred by chance, it seems desirable to increase the awareness of gender-specific sensitivity to cigaretre smoke and to report such findings more systematically.

In chapter 11 the effect of matemal smoking on neonatal haemostasis has been studied. Twenty-six newborms of smoking mothers and 25 newborns of non-smoking mothers were included. To monitor coagulation acrivation, levels of prothrombin fragment $1+2$ (F 1+2) and thrombin antithrombin III (TAT III) were measured, Plasmin- $\alpha_{2}$ antiplasmin complex (PAP) and D-dimer levels were determined in order to assess fibrinolytic activity. The findings in healthy term infants born after an uncomplicated pregnancy were consistent with a hypercoagulable state. TAT III levels were high immediately after birth. The finding of the equally high $\mathbb{D}$-dimer values reflects coagulation activation with reactive fibrinolysis in the newborn. This physiological process was not influenced by tobacco smoke exposure.

In chapter 12 the previous chapters and future research goals are discussed. Future studies should focus on the question wherher cigarette smoking changes the funcrional characteristics of blood cells. Investigations in the field of molecular biology are necessary to obtain insight in the individual effects of the numerous compounds of cigaretre smoke.

In summary, it can be concluded that;

1. Cotinine, the principal metabolite of nicotine, is easily transferred to the noonatal compartment. There seems to be a threshold of around 10 cigarettes/day.

2. Smoking during pregnancy has an addirive enhancing effect on the rotal leucocyte count.

3. Smoking in pregnancy leads to a lower erythrocyte count and a higher mean cell volume $(\mathrm{MCV})$.

4. Smoking during pregnancy does not affect reticulocyte and platelet count and indices in a clinically relevant way.

5. In pregnant women who smoke the activated coagulation process is not counterbalanced by an increase of fibrinolysis, as is the case in their non-smoking counterparts.

6. Smoking during pregnancy has a negative effect on the neutrophil count in neonates. Male newborns are more affected by cigaretre exposure than female newborns.

7. The balance between the components of the coagulation and fibrinolytic pathways in the neonates is not disturbed by maternal smoking. 
8. On account of these findings counselling of women who smoke should have a high priority in anrenatal care. Pregnant women who continue to smoke should be counselled to stop for their own health and the health of their unborn child.

9. Future studies should focus on the effect of smoking on the functional characteristics of blood cells. Studies in the field of molecular biology will be necessary to obtain more insight in the individual effects of the numerous components of tobacco smoke. 


\section{Chapter 14}

\section{Samenvatting}

In West-Europa rookt 36\% van de bevolking. Van de Nederlandse vrouwen in de vruchrbare levensfase rookt $30 \%$. Voor mannen in dezelfde leefrijdscategorie bedragr dit percentage 36. Uit onderzoek naar rookgedrag blijkt dat een derde van de Nederlandse vrouwen tijdens de zwangerschap blijft roken. Afhankelijkheid van nicotine is de belangrijkste oorzaak van dit gedrag.

In hoofdstuk I wordt de farmacologie van nicotine, cotinine, koolmonoxide en thiocyanate beschreven. Het bepalen van de cotinine-concentratic is de beste methode om onderscheid te maken cussen rokers en niet-rokers. De cotinine-concentraties in plasma en melk van de moeder en in plasma en urine van het kind aijn immers goede gradometers voor het objecriveren van het rookgedrag tijdens de zwangerschap.

Vervolgens wordt een overzicht gegeven van het effect van roken op de bloedcellen en de haemostase. In meerdere onderzoeken is aangetoond dat bij rokers het totale aantal wirte bloedcellen groter is dan bij niet-rokers. Deze toename betreft met name het aantal monocyten. Het blijkt moeilijk vast te stellen of roken de reactie van de ontstekingscellen verhoogt of verlaagt. Koolmonoxide bindt zich aan haemoglobine, hergeen kan leiden tor hypoxaemie en op termijn tot polycythaemie. Her verband tussen roken en polycythaemie is vaker beschreven. Roken leidt tot activatie van de thrombocyten. Dit effect wordt met name aan nicotine toegeschreven en leidt tor een verhoogde adhaesie van de thrombocyten aan de vaatwand. De aggregatie van deze cellen wordr acuut versterkt door roken.

Het roken rijdens de zwangerschap kan leiden rot een chronische hypoxie bij het kind. Enerzijds kan dit effect het gevolg zijn van de vervanging van oxyhaemoglobine door carboxyhaemoglobine. Anderzijds kan het roken leiden tor structurele veranderingen in de placenta en een verminderde placentaire doorbloeding, hetgeen een verminderde zuurstofvoorziening voor de foetus betekent.

Roken heef ook invloed op de coagulatie. Onderzocken laten bij rokers hogere warden zien voor fibrinogeen en thrombine-antirhrombine III. Het effect van roken op de fibrinolyse is nog onduidelijk, ondat zowel toename als afname van fibrinolyse worden gemeld.

In hoofdstuk 2 wordt een uitgebreid overzicht gegeven van de uit de lireratuur naar voren komende mogelijke gevolgen van her roken door vrouwen rijdens de vruchitbare levensfase en de zwangerschap. 
De mechanismen, die leiden tot de negatieve effecten van her roken tijdens de zwangerschap zijn zeer complex. In de volgende hoofdstukken wordt onderzocht wat de betekenis is van haematologische veranderingen bij de rokende moeder en/of haar kind voor de verklaring van die mechanismen. Het onderzoek richt zich daartoe met name op:

1. Her effect van roken op bloedcellen en indices bij moeders (de hoofdstukken 4, 5 , 6 en 7) en pasgeborenen (hoofdstuk 9).

2. De sexe-afhankelijke verschillen in de gevolgen voor pasgeborenen van her rookgedrag van de moeder tijdens de zwangerschap (hoofdsruk 10).

3. De simultane effecten van roken en zwangerschap op de haemostase (hoofdstuk 8).

4. De verschillen in haemostase tussen pasgeborenen van rokende en van niet-rokende moeders (hoofdseuk 11).

5. Her bepalen van de corinine-concentratie in maternaal en navelstreng-bloed om vast te stellen in welke mate de foetus bij een rokende moeder wordt blootgesteld aan rookcomponenten (hoofdstuk 3 ).

In hoofdstuk 2 wordt een overzicht gegeven van de literatuur met betrekking tot roken en reproductie. Roken wordt geassocieerd met een dosisafhankelijke afname van bevruchting en vruchtbaarheid bij vrouwen en met een verminderde spermakwaliteit bij mannen. Roken heeft ook een negatief effect op het verloop van de zwangerschap. Er wordt een toename van bloedingen en placenta praevia beschreven. Roken wordt verder in verband gebracht met miskramen, laag geboortegewicht, perinatale sterfte en wiegedood. De perinatale sterfte is in een aantal gevallen te wijten aan een verhoogde kans op ernstige malformaries. Kinderen van rokende moeders worden tweemaal zo vaak in het ziekenhuis opgenomen vanwege longproblematiek. De relatie tussen roken rijdens de zwangerschap en her bij het kind optreden van kanker op jeugdige leeftijd is nog onzeker. In hoofdstuk 3 worden de resultaten weergegeven van de mering van cotinine-concentraties bij rokende moeders en hun kinderen. Tabaksrook bestaat uit meer dan 3600 verschillende stoffen. Nicotine is een van de farmacologisch meest actieve componenten. Nicotine wordt omgezet in cotinine en die stof vormt de beste biochemische maatstaf voor objectivering van rookgedrag. Cotinine is namelijk specifiek voor het inademen van tabaksrook en het heeft een lange halfwardetijd (10-20 uur). Nicotine-en cotininemetingen werden verricht bij 25 rokende en 25 niet-rokende gezonde zwangere vrouwen. Bijalle niet-rokende vrouwen werden nicotine- en cotininewarden $<10 \mu \mathrm{g} / \mathrm{ml}$ gevonden. Bij vrouwen die minder dan 10 sigaretren per dag rookten was de nicotinewaarde $<10 \mu \mathrm{g} / \mathrm{ml}$ en varieerde de cotininewaarde tussen 40 en $99 \mu \mathrm{g} / \mathrm{ml}$. Bij een gebruik van 10 of meer sigaretten per dag bleef de nicotinewaarde laag $(<10 \mu \mathrm{g} / \mathrm{ml})$, maar steeg de cotininewarde naar 115 tot $199 \mu \mathrm{g} / \mathrm{ml}$.

Bij 25 pasgeborenen van niet-rokende moeders en 34 pasgeborenen van rokende moeders werden de cotinine-concentraties bepaald. De moeders van 9 van deze 34 neonaten namen deel aan het onderzoek om de relatie tussen maternale en neonatale corininewarden te bestuderen. De corininewaarden bij pasgeborenen van niet-rokers 
en lichre rokers waren $\leq 10 \mu \mathrm{g} / \mathrm{m}$. De cotininewarden bij pasgeborenen van moeders, die 10 of meer sigaretten per dag rookten, waren significant hoger dan bij pasgeborenen van moeders die minder rookten, maar significant lager dan de waarden bij hun eigen moeders. Voor de cotinine-overdracht van moeder naar kind lijkt er sprake te zijn van een drempel als de consumptie beneden de 10 sigaretten per dag blijft.

Metingen bij zwangere vrouwen bevestigen dat via cotininebepaling een beter zicht op het werkelijk rookgedrag verkregen kan worden dan via nicorinebepaling.

De cotinine-concentraties bij neonaren zijn significant lager dan bij hun moeders, maar er is cen sterke positieve lineaire relatie tussen de maternale en de neonatale cotinineconcentraties.

In hoofdstuk 4 worden de resultaren van leucocytentelling bij 194 rokende en 518 niet-rokende gezonde zwangere vrouwen beschreven. Roken doet her rijdens de zwangerschap toch al stijgend aantal leucocyten nog verder toenemen. De leucocytendifferentiatie bij 105 rokende en 288 nier-rokende zwangere vrouwen toont aan dat de eosinofielen en de basofielen niet en de neutrofielen, monocyten en lymfocyten wel aan deze toename bijdtagen. Deze leucocytose bij rooksters is dosisafhankelijk. Er wordt een significante toename van het percentage leucocytose gezien bij de toename van het atntal sigaretten per dag van 12 naar 15 en van 19 naar 20.

In hoofdstuk 5 worden de erythrocyten, erythrocyrenindices alsmede de haemoglobineen haematocrietwaarden bij 247 niet-rokende en 123 rokende zwangere vrouwen vergeleken. De metingen werden verricht in de volgende stadia van de zwangerschap: 0-10,11-20, 21-30 en 31-40 weken. De bepalingen werden uitgevoerd mer behulp van. de Sysmex NE-8000. Het aantal erythrocyten bleek in de laatste 10 weken van de zwangerschap bij rooksters significant lager dan bij niet-rooksters: $3,86 \times 10^{12 /]}$ versus $3,96 \times 10^{12} / 1$. In alle gevallen was er sprake van een daling van het aantal erychrocyten. $\operatorname{Van} 4,32 \times 10^{12 / 1}$ tot $3,96 \times 10^{12 / 1}$ bij de niet-rooksters en van $4,24 \times 10^{12 / 1}$ tot 3,86 $\times 10^{12} / \mathrm{l}$ bij de rooksters. De verschillen in de mediane hacmoglobine- en haematocrict waarden waren verwaarloosbaar klein. De MCV was, cvenals de MCH, in de latste 10 weken wan de zwangerschap significant hoger bij de rooksters: MCV 91 月en MCH 1.90 fmol bij de rooksters en $94 \mathrm{ft}$ en 1.95 fmol bij de nier-rooksters.

Roken tijdens de zwangerschap leidt tor een lager aantal erythrocyten en een hogere MCV, hetgeen onder bepaalde omsrandigheden kan Jeiden tot cen hypoxie bij de foetus. In hoofdstuk 6 worden de reticulocyten en de subfracries daarvan bij rooksters en niet-rooksters vergeleken. De benodigde bepalingen werden uitgevoerd met behulp van de Sysmex R-3000 reticulocytenteller. Dit apparaat verstrekt exacte antallen reticulocy. ten en geeft informatie over de rijpheid van deze cellen door bepaling van de fluorescenrie-intensiteit alls weerspiegeling van de RNA-inhoud van de cel. De RNA-inhoud van reticulocyten vermindert met het ouder worden. Een hoge fluorescentieratio duidt derhalve op veel jonge reticulocyten.

Het aancal reticulocyren was lager bij rooksters, maar dit was alleen in de laatste 10 weken significant: $71,9 \times 10^{9} / 1$ versus $78,8 \times 10^{\%} / 1$. Er was geen verschil in de fluorescentieratio's 
ussen rooksters en niet-rooksters, terwijl er bij beide groepen sprake was van een afname wa het ancal on rijpe reticulocyen.

In hoofdstuk 7 worden de thrombocyten-aantallen en -indices bij rooksters en nietrooksters vergeleken. V roeger uigevoende onderzoeken beperkten zich meestal tot her rellen van de thrombocyten rijdens de zwangerschap. Bij het onderhavige onderzoek werd echter ook de mogelijkheid betrokken dat het combineren wan thrombocytenaantal mer indices zoals gemiddeld plarjeswolume (MPV), de distributiewijte van platies (PDW) en plateletcrit (PCT) en berer inzicht in het effect van roken op de biologie van de trombocyten zou kumnen geven.

Bij de nict-rooksters daalde her aantal thrombocyten significant rijdens de zwangerschap: van $287 \times 10^{9} / 1$ naar $258 \times 10^{\circ} / 1$. Bij de rooksters was dit nier het geval. De MPV was gedurende de latste 10 weken wan de zwangerschap bij tooksters significant lager dan bij niet-1rooksters: 10,4 $\mathrm{A}$ versus 10,7 fl. De PDW en PDT veranderden nier onder invloed van roken.

In hoofdstuk 8 worden coagularie en fibrinolyse bij rokende $(n=57)$ en niet-tokende $(n=44)$ zwangere wrouwen onderzochr. Prothrombine fragment $1+2(F 1+2)$ en thrombine-antithrombine III (TAT III) werden bepaald als graadmeters woor de stollingsacrivatile, plasminogeen, $\alpha_{2}$-antiplasmine en D-dimeren als graadmeters voor de fibrinolyse.

Roken bleck geen additioneel effect te hebben op de tijdens zwangerschap toch al geacriverde coagulatie. Roken leidde wel tor een afname van de fibrinolyse. Bif rokende zwangere vrouwen wordt de geactiveerde coagulatie derhalve niet gecompenseerd door een toename van de fibrinolyse, hetgeen wel het geval is bij niet-rooksters.

In hoofdstuk 9 worden gevolgen van het roken door de moeder voor de bloedcellen van de pasgeborene onderzocht. Daartoe werden leucocyten, thrombocyten, erythrocyten, reticulocyten en de indices daarvan bepaald in navelstrengbloed van 89 pasgeborenen van nict-rokende moders en 53 pasgeborenen wan rooksters. Aantlen en indices wan erythrocyten en thrombocyten leverden geen verschillen op russen beide groepen. Het antal rericulocyten was significant lager bij kinderen van rooksters, maar de rericulocyrensubsets waten niet werschillend. Her an nal neurofielen was eveneens significant lager bij de kinderen van rokende moeders. Deze bevinding zou een verklaring kunnen vormen voor het feit dat de kinderen van rokende moeders vaker luchtweginfecties hebben.

In hoofdstuk 10 wordt andach bestecd an mogelijke sexe-afhankelijke gevoeligheid voor rabaksrook. Daartoe werden de in hoofdstuk 9 genoemde warden bepaald in navelstrengbloed van 64 mannelijke en 75 vrouwelijke pasgeborenen van 87 niet-rokende en 52 rokende moeders. Aantallen leucocyten en neurrohelen waren significant lager bij mannclijke dan bij vrouwelijke pasgeborenen varn rooksters.

Ondanks het feir dat het onderzock zich op meer dan 40 variabelen richte, en sommige verschillen mogelijk a an toeval te wijen zijn, lijkt het wenselijk arandacht re besteden an sexe-athankelijke gevoeligheid voor tabaksrook. 
In hoofdstuk 11 wordt het effect van roken op de neonarale haemostase beschreven. Bii dit onderdeel van het onderzoek waren 26 pasgeborenen van rokende en 25 wan niet-rokende moeders berrokken. De coagullarie werd onderzocht door middel van bepaling van F $1+2$ en TAT III en de fibrinolyse door middel van plasmine- $\alpha_{2}$-antiplasmine-complex (PAP) en D-dimeerbepalingen. Hoge TAT III-en D-dimeer-concentraties in de gezonde pasgeborenen duiden op coagulatie activarie mer reacrieve fibrinolyse. Dir fysiologische proces blijkr bij pasgeborenen nier beïnloed te worden door het rookgedrag van de moeder.

In hoofdstuk 12 worden de voorafgande hoofdstukken en mogelijke roekomstige onderzoeksprojecten besproken. In die projecten zou mer name aandach bested kunnen worden aan de vraag of roken de functie van bloedcellen verandert. Moleculairbiologisch onderzoek zal nodig zijn om meer inzicht te verkriigen in de effecten van de talrijke afzonderlijke bestanddelen van tabaksrook.

Samenvatrend kunnen de volgende conclusies getrokken worden:

1. Corinine, de belangrijkste metaboliet van nicotine, wordt gemakkelijk getransporteerd naar de foetus en de neonaat. Dat lijkt met name het geval wanneer de moeder meer dan 10 sigaretten per dag rookt.

2. Zwangerschap veroorzaakt een stijging van het aantal leucocyten. Roken rijdens de zwangerschap leidt tot een verdere toename van het aantal leucocyten.

3. Roken tijdens de zwangerschap veroorzaakr een daling van het aantal erythrocyten en een toename van thet gemiddelde celvolume (MCV).

4. Roken tijdens de zwangerschap heeft geen klinisch relevant effect op het itantal reticulocyten en de subfracties daarvan.

5. Bij zwangere vrouwen die roken, wordt de geactiveerde coagulatie niet gecompenseerd door een toename van de fibrinolyse. Bij niet-rooksters is dat wel het geval.

6. Roken tijdens de zwangerschap veroorzakt een daling van het antal neutrofieken bij de pasgeborene. Bij mannelijke pasgeborenen is dit in hogere mare her geval dan bij vrouwelijke.

7. Bij pasgeborenen blijkt het evenwicht tussen coagulatic en fibrinolyse niet verstoord als hun moeders tijdens de zwangerschap rookren.

8. Op basis van bovenstaande conclusies dient vrouwen in de vruchtbare levensfase te worden geadviseerd om te stoppen met roken. Dit zowel terwille van hatar cigen gezondheid, als terwille van de gezondheid van haar ongeboren kind.

9. Het lijkt zinvol voortgezet onderzoek mer name te richten op het eftect van roken op de functie van de bloedceillen. Moleculair biologisch onderzoek zal nodigzijn om meer inziche te verkrijgen in de effecten van de allrijke afzonderlijke bestanddelen van tabaksrook. 



\section{Dankwoord}

Dit proefschrift werd bewerki binnen de afdeling Obsterrie en Gynaecologie van Ziekenhuis De Wever en St. Gregorius, lokatie Heerten (opleider: Dr. J. Stoor). Het bloedonderzoek vond plaats binnen de afdeling Haemarologie van hetzelfde ziekenhuis (hoofd: Dr. J. wan Wersch).

Bij her tot stand komen van dit proefschrift waren velen direct of indirect betrokken. Hen allen ben ik erkentelijk voor de pretrige en produktieve samenwerking. Met name dank ik:

De promotores, Prof. Dr. P. Brombacher voor zijn hulp en diplomatieke atanwijzingen en Prof. Dr. J. de Haan voor zijn opbouwende kriciek.

De co-promotor Dr. J. van Wersch, die mij in de gelegenheid stelde om mij te verdiepen in de haematologie. Zijn niet aflatend enthousiasme en inzet vormen de fundamenten van dit proefschrift.

De co-promotor Dr. J. Ubachs, die mij op vaderlijke wijze in de juiste richting geleid heeft. Ik verheug me op een nog langdurige samenwerking.

Diverse vakspecialisten, die bij de bewerking van de verschillende onderzoeksprojecten hebben meegewerkt: Dr. H. Schouten (statistiek), J. Schep (informatica), W. Hanssen, S. Schröder, R. Nieuwenhuysen, J. Smeets en de overige medewerkers van het haematologisch laboratorium en de verpleegkundigen van de verloskamer. Zonder hun hulp was het proefschrift niet tot stand gekomen.

Dr. B. Davies voor zijn Britse inbreng en Kate voor haar overaeese suggesties. J. Houben voor zijn taalkundige adviezen.

Rosemarieke Breukers en Diana Voncken voor hun inzet en betrokkenheid bij dit project.

De bibliothecaressen Miriam Wetzels, Romy Cligner en Edith Wierts, die zeer nauwkeurig de referenties corrigeerden.

Jan Hendrik Ubachs voor het ontwerpen van de fraaic kaft. 
En matuurlijk Petra Hawinkels voor haar constante secretariële ondersteuning. Haar humeur bleef desondanks constant!

Bijzonder waardeer ik de hulp van de stafleden van de afdeling Obsterrie/Gynaecologie, die mij, naast een gedegen opleiding, de mogelijkheid gaven dit onderzoek rot een goed einde te brengen. lets wat zonder de collegialiteit van mijn mede-assistenten heel moeilijk zou zijn geweest.

De wriendschap van Karin en Sjef is voor mij heel belangrijk.

Tenslotre dank ik mijn ouders en Fia en Chrit voor hun mentale support en culinaire verrassingen, en mijn schoonouders voor de ondersteunende long distance calls.

Luc, bo ta mi premio major! 


\section{Curriculum vitae}

1964

$1971-1977$

$1984-1985$

1985

1987 jan-maart Keuzevak Obstetrie en Gynaecologie. Hospital Clinico de San Carlos, Madrid, Spanje

1990

1990-1991 Arts-assistent Obstetrie en Gynaecologie, Ziekenhuis De Wever en St. Gregorius, lokatie Brunssum

1991-1992 Arts-assistent Obstetrie en Gynaecologie, St. Elisabeth Hospital, Willemstad, Curaçao

1992-heden Assistent geneeskundige in opleiding, Obstetrie en Gynaccologic, Ziekenhuis De Wever en St. Gregorius, lokatic Heerlen 